UNIVERSIDADE DE SÃO PAULO ESCOLA DE COMUNICAÇÕES E ARTES

Sarah Alencar Alves

\title{
Mulheres que criam com vozes
}

SÃO PAULO

2019 


\section{Mulheres que criam com vozes}

\section{Versão original}

Dissertação apresentada à Escola de Comunicações e Artes da Universidade de São Paulo para obtenção do título de Mestre em Música.

Área de Concentração: Musicologia

Orientadora: Profa. Dra. Susana Cecília Igayara-Souza

São Paulo

2019 
Nome: ALVES, Sarah Alencar

Título: Mulheres que criam com vozes

Dissertação apresentada à Escola de Comunicações e Artes da Universidade de São Paulo para obtenção do título de Mestre em Musicologia.

Aprovada em:

\section{Banca Examinadora}

Profa. Dra.

Instituição:

Julgamento:

Profa. Dra.

Instituição:

Julgamento:

Profa. Dra.

Instituição:

Julgamento: 


\section{Agradecimentos}

À minha mãe Nislene Borges pelas conversas, carinho e revisão deste texto.

Ao meu pai Danilo Alencar, irmã Andreia Oliveira, padrasto André Monteiro e toda minha família pelo apoio incondicional em minha caminhada.

À orientadora deste trabalho Profa. Dra. Susana Igayara pelo cuidado e confiança.

Aos amigos Carlos Eduardo Samuel e Danilo Sene e à amiga Rita Maria pelas longas conversas que tanto contribuíram para trilhar os rumos desta pesquisa, e pelas descobertas artísticas em nossas parcerias.

Às amigas Alice Máximo, Carol Braga, Camilla Veles e Giu de Castro do Teatro Labirinto pelo amparo, força e possibilidade de me redescobrir em performance, processo e ação.

Ao Coro Profana, primeiro espaço coletivo em que pude experimentar a voz livremente.

Às amigas Alice Oliveira e Priscila Ribeiro, parceiras do Trio Maria Fumaça e da vida.

Às amigas e amigos que moram comigo - minha querida família paulistana - pelos cafés e paciência. 


\section{RESUMO}

Este trabalho tem como objetivo investigar, pelo viés da pesquisa artística e à luz dos debates sobre gênero e música na musicologia, de que maneira três artistas ligadas a diferentes práticas criativo-performáticas trabalham vozes a partir de temáticas relacionadas ao corpo e gênero. Neste contexto é fundamental a perspectiva da performance, abordada neste trabalho a partir de três pontos de vista: da musicologia, que estabelece a música enquanto fazer prático e processo de significado social; dos estudos da performance, propostos por Richard Schechner; e da performatividade de gênero, trabalhada por Judith Butler. Neste âmbito, o debate sobre questões de gênero - nos contextos em que as atividades artísticas se dão - é essencial. As artistas estudadas são Jocy de Oliveira, que vem de uma tradição de música escrita contemporânea e dialoga com encenação teatral; Iara Rennó, que traz a prática da canção popular; e Flora Holderbaum, que desenvolve trabalhos na área da música experimental e eletroacústica. Partindo da perspectiva da pesquisa artística também é realizado um laboratório de criação e performance a partir de relatos e reflexões acerca do projeto $O$ canto para $o$ jardim de veredas, do grupo Teatro Labirinto. Em tal laboratório são experienciados e discutidos recursos e processos observados nos trabalhos das artistas e bibliografia estudadas. Nesta pesquisa como um todo foi observada a maneira com que trabalhos artísticos vocais, que se propõem a explorar o canto como expressão da singularidade, participam na reivindicação do corpo enquanto forma de organização do mundo. Dessa maneira, é subvertido o paradigma cartesiano que separa a mente - associada no discurso hegemônico patriarcal a uma ideia de masculino - do corpo - tradicionalmente associado a uma ideia de feminino.

Palavras-chave: Mulheres. Voz. Gênero. Canto. Performance. 


\begin{abstract}
This work aims to investigate, through the bias of artistic research and in the light of the debates about genre and music in musicology, how three artists - linked to different creative-performance practices - work with voices from themes related to body and gender. In this context it is fundamental the perspective of the performance, approached in this work from three points of view: the musicology, that establishes the music as practice and process of social meaning; of the performance studies proposed by Richard Schechner; and of the performativity of genre, proposed by Judith Butler. In this context, the debate on gender issues - in contexts in which artistic activities take place - is essential. The studied artists are Jocy de Oliveira, who emerges from a tradition of contemporary written music and dialogues with theatrical stage; Iara Rennó, who works with the practice of popular song; and Flora Holderbaum, who develops works of experimental and electroacoustic music. On the perspective of artistic research, a laboratory of creation and performance is also developed, based on reports and reflections on the project Canto para o jardim de veredas, by the group Teatro Labirinto. In this laboratory, resources and processes observed in works of the studied artists and bibliography are experienced and discussed. In this research was observed the way in which vocal artistic works that propose the exploration of singing as expression of the singularity participate in the claim of the body as form of organization of the world. In this way, the Cartesian paradigm that separates the mind of the body is subverted, in which the mind is associated in the patriarchal hegemonic discourse with an idea of masculine and the body is traditionally associated with an idea of feminine.
\end{abstract}




\section{LISTA DE ILUSTRAÇÕES}

\section{FIGURA}

Figura 1- Gráfico de ingressantes no Bacharelado em Composição da Universidade de

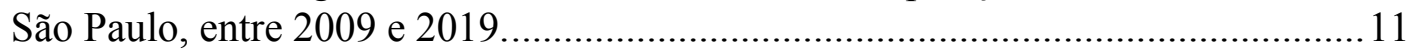

Figura 2 - Espectrograma da Microvoz I (HOLDERBAUM, 2016).............................2 28

Figura 3 - Imagem utilizada no Soundcloud de Flora Holderbaum, em 5 peças para

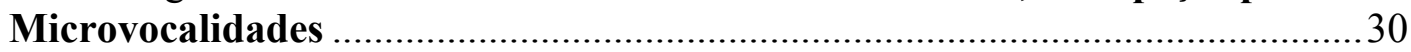

Figura 4 - Gráfico de camadas da micropeça Escri3ura (HOLDERBAUM, 2016)....... 32

Figura 5 - Espectrograma da Miniatura Vocálica II (HOLDERBAUM, 2016) ..............36

Figura 6 - Ophelia, John Everett Millais, 1851-52 ................................................ 41

Figura 7 - Quadro sobre a relação atrizes- personagens em Ofélia presa nas cordas do

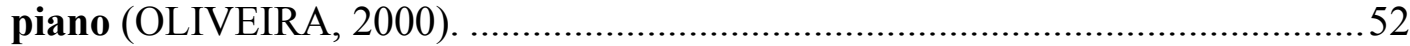

Figura 8 - Iara Rennó performando Macunaíma Ópera Tupi ......................................63

Figura 9 - Capas dos discos Arco e Flecha (RENNÓ, 2016). ......................................65

Figura 10 - frames do clipe de Mama-me, (RENNÓ, 2016).........................................74

Figura 11 - Abertura de processo do Canto para o jardim de veredas, no V Encontro

de Teatro Universitário. ....................................................................................... 83

Figura 12- post da integrante Camilla Veles sobre o processo em Canto para o jardim

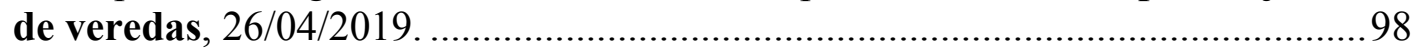

\section{TABELAS}

Tabela 1 - Estrutura de Ofélia presa nas cordas do piano, de acordo com recursos

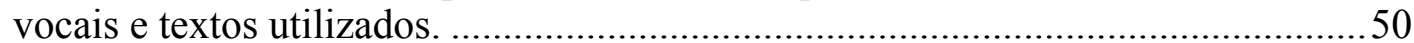

Tabela 2 - Mapeamento de características vocais em Arco (RENNÓ, 2016).................66

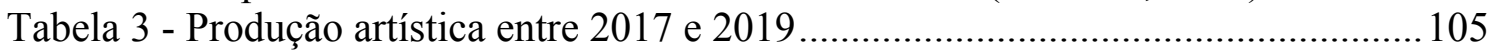

\section{PARTITURAS}

Partitura 1 - Ofélia presa nas cordas do piano, Jocy de Oliveira...............................46

Partitura 2 - Transcrição do trecho 0:37 - 0:49 da música Meus vãos (RENNÓ, 2016).

Partitura 3 - Ciclo da caixa da bateria do trecho 0:37 - 0:49 da música Meus vãos

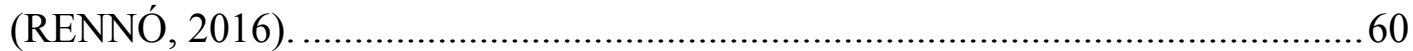

Partitura 4 - Transcrição do ostinato do clarone (sons reais) do trecho 01:24 - 01:58 da

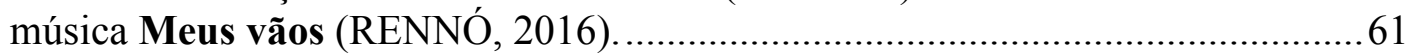

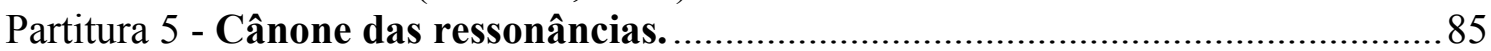

Partitura 6- Célula rítmica principal de O que foi feito devera (de Vera) (entre 3:55 ao

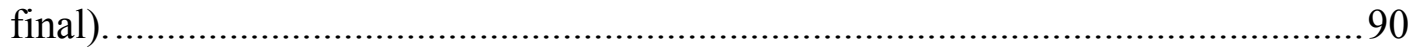

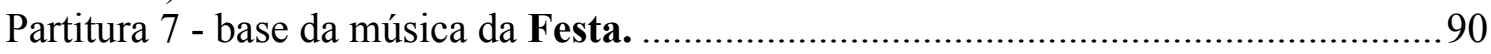

Partitura 8- solo e base da música da Festa................................................................ 90 


\section{SUMÁRIO}

SUMÁRIO

CAPÍTULO 1 - O CORPO-VOZ NA MÚSICA: PERFORMANCE E 5 PEÇAS

PARA MICROVOCALIDADES, DE FLORA HOLDERBAUM …….......................2

1.1 Performance, performatividade e os estudos da performance .........................20

1.2. 5 peças para Microvocalidades, Flora Holderbaum ......................................... 24

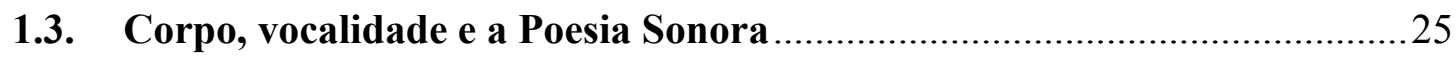

1.4. Poema Poço B'arthesiano ou "onda do estylo ga(l)go" e a Microvoz 1 1......26

1.5. Vocalidades mínimas, ou Microvocalidades, os grãos e os materiais..........30

1.6. Grãos sonoros e grão da voz: mais um espaço criado.....................................34

1.7. Traços de vocalidade nas ressonâncias por extensão ……………………........35

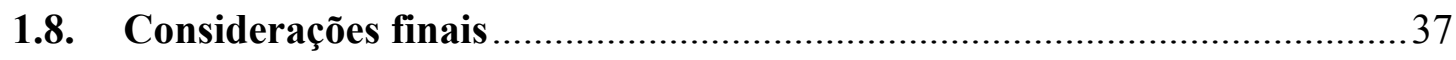

CAPÍTULO 2 - VOZ E SUBVERSÃO DA LINGUAGEM DA ÓPERA: OFÉLIA

PRESA NAS CORDAS DO PIANO, DE JOCY DE OLIVEIRA................................39

2.1. Ofélia presa nas cordas do piano, de Jocy de Oliveira: subversão dos

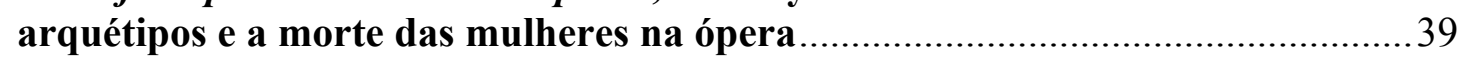

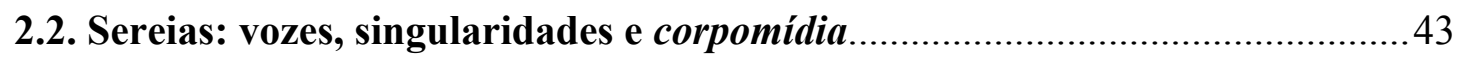

2.3. Vocalidades e aspectos vocálicos em Ofélia presa nas cordas do piano ...........45

2.4. Aspectos performativos: teatralidade, multimídia e metalinguagem ............51

2.5. Considerações finais do capítulo ...................................................................5

CAPÍTULO 3 - A REIVINDICAÇÃO DO CORPO: ARCO, DE IARA RENNÓ .. 56

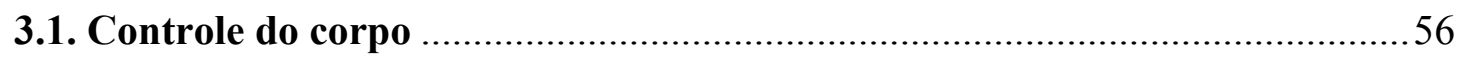

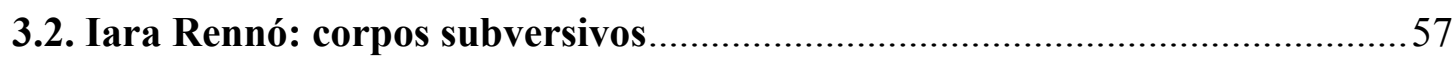

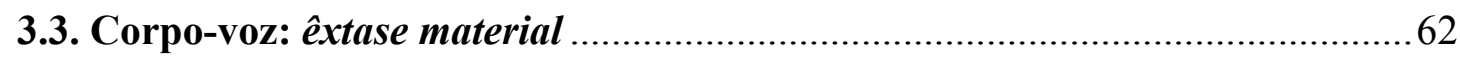

CAPÍTULO 4 - PERFORMANCE NA MÚSICA: FUNÇÕES E MODOS DE

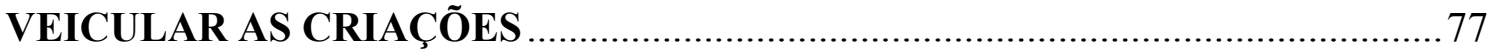

4.1. A performance na música e musicologia: questões sobre práticas musicais 77

4.2. Trânsito entre práticas: relato de uma trajetória .............................................. 80

4.3. Canto para o jardim de veredas, grupo Teatro Labirinto.................................... 82

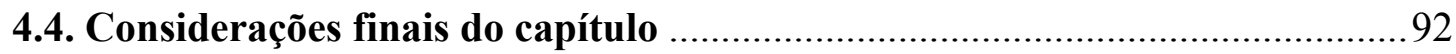

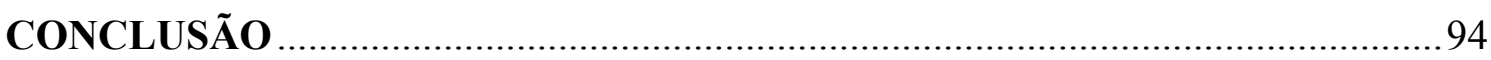

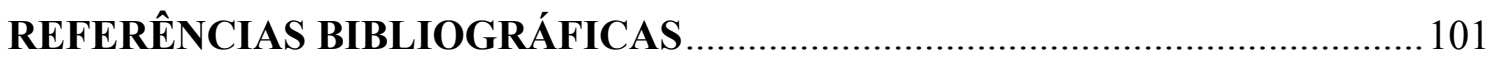




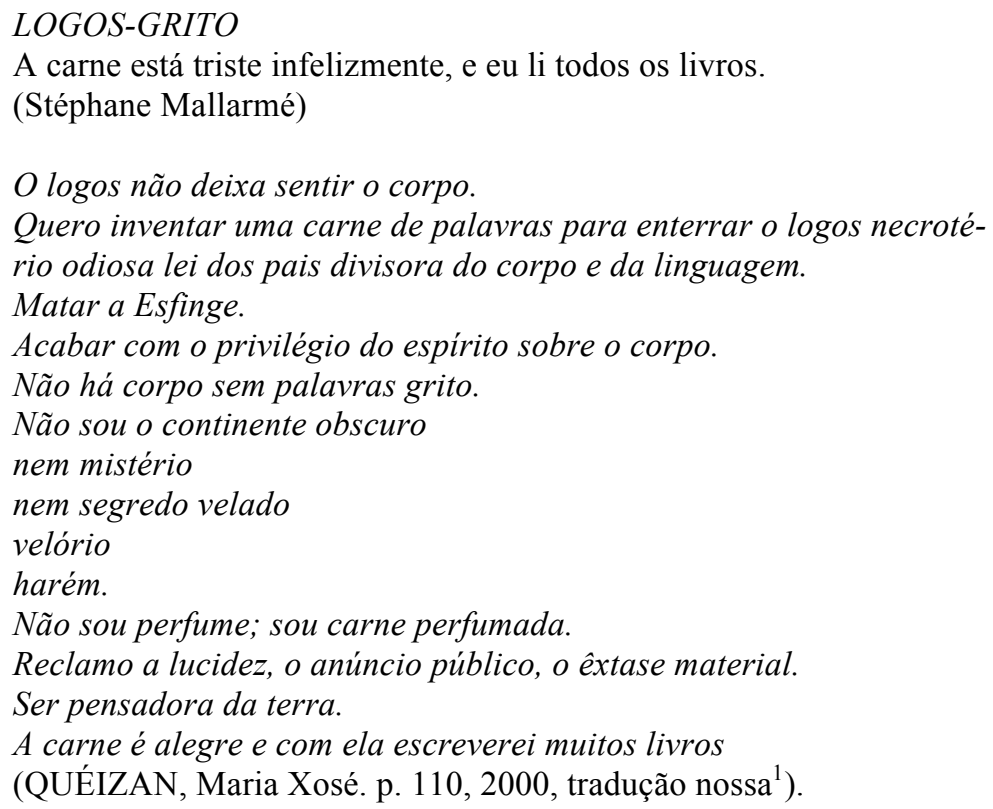

\footnotetext{
${ }^{1}$ Poema publicado originalmente no livro Despertar das amantes, Espiral Maior, 1993. Versão original: LOGOS-GRITO

La chair est triste hélas, et j'ai lu tous les livres.

O logos non deixa sentir o corpo.

Quero inventar unha carne de palavras para enterrar ao logos mortuorio odiosa lei dos padres divisora do corpo e da linguaxe.

Matar a Esfinxe.

Acabar co privilegio do espírito sobre o corpo.

Non hai corpo sen palavras grito.

Non son o continente obscuro'

nin mistério

nin secreto velado

valetorio

harén.

Non son perfume; son carne perfumada.

Reclamo a lucidez, o anuncio público, a éxtase material.

Ser pensadora da terra.

A carne é leda e con ela escribirei moitos libros.

(QUÉIZAN, Maria Xosé, p. 110, 2000).
} 


\section{INTRODUÇÃ̃O}

Ela se arrasta sorrateira e esquadrinha as montañas e os arroyos, leitos secos de rios, à procura de ossos de lobos e, quando consegue reunir um esqueleto inteiro, quando o último osso está no lugar e a bela escultura branca da criatura está disposta à sua frente, ela senta junto ao fogo e pensa na canção que irá cantar.

Quando se decide, ela se levanta e aproxima-se da criatura, ergue seus braços sobre o esqueleto e começa a cantar. É aí que os ossos das costelas e das pernas do lobo começam a se forrar de carne, e que a criatura começa a se cobrir de pelos. La loba canta um pouco mais e uma proporção maior da criatura ganha vida. Seu rabo forma uma curva para cima, forte e desgrenhado.

La loba canta mais, e a criatura-lobo começa a respirar.

$E$ La Loba ainda canta, com tanta intensidade que o chão do deserto estremece, e enquanto canta, o lobo abre os olhos, dá um salto e sai correndo pelo desfiladeiro.

Em algum ponto da corrida, quer pela velocidade, por atravessar um rio respingando água, quer pela incidência de um raio de sol ou luar sobre seu flanco, o lobo de repente é transformado numa mulher que ri e corre livre na direção do horizonte

(ESTES, Clarissa Pinkola, p. 23-24,1999).

Por indicação de uma amiga tive contato em 2016 com o livro Mulheres que correm com os lobos, da Clarissa Pinkola Estes. O primeiro conto - La loba - me impactou muito, afinal como cantora e compositora dificilmente não me impressionaria ao me deparar com a história fantástica de uma mulher que cria a vida com sua voz. O primeiro impulso foi compor um solo vocal baseado no conto. Porém a pesquisa extrapolou o plano da criação artística e emergiu enquanto interesse para desenvolver este mestrado.

O recorte escolhido para a pesquisa - das mulheres que criam com vozes - reportase a dois campos: o de gênero e da voz, enquanto exploração artística no âmbito da música. A questão do gênero salta muito aos olhos nos ambientes da música quando se é mulher ligada à esfera da composição, já que a diferença numérica entre gêneros neste âmbito é gritante. No gráfico a seguir foi realizado um levantamento da relação entre mulheres e homens ingressantes no curso de Bacharelado em Composição na Universidade de São Paulo - USP, entre 2009 - ano que ingressei na instituição - e 2019.

Figura 1- Gráfico de ingressantes no Bacharelado em Composição da Universidade de São Paulo, entre 2009 e 2019. 


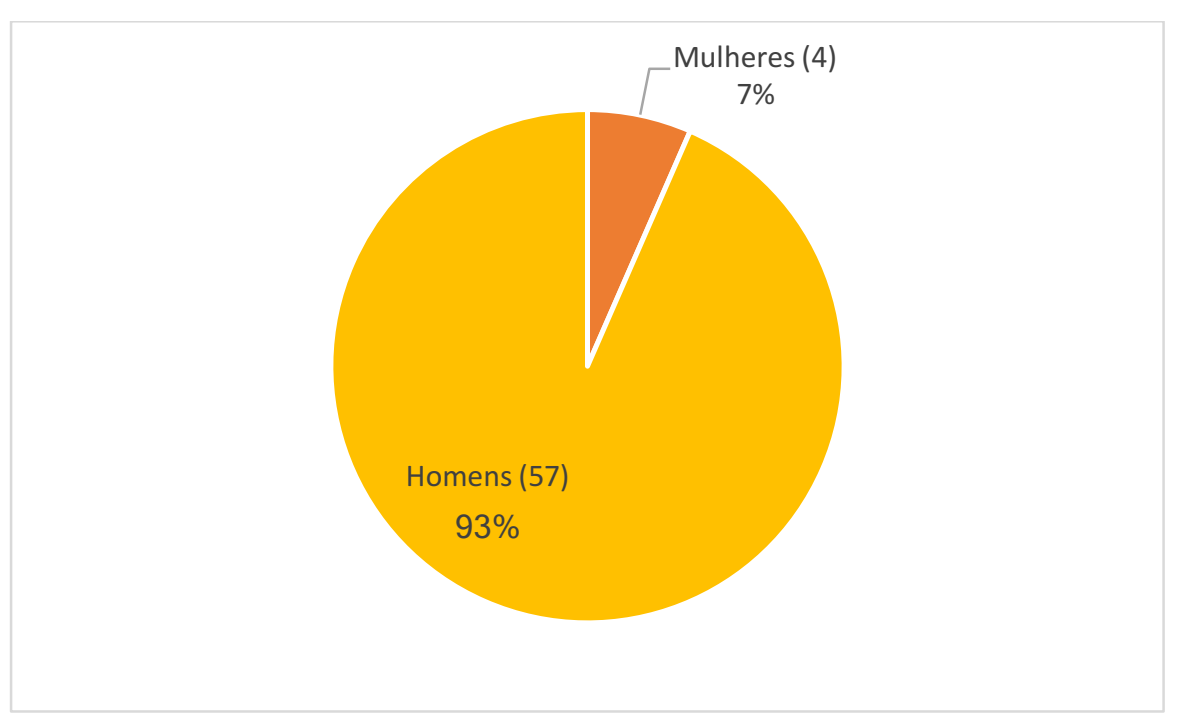

Fonte: gráfico produzido para este trabalho ${ }^{2}$.

A intenção deste gráfico não é sua análise no sentido de explicar as razões para que tal diferença numérica aconteça, mas sim discutir as motivações para que esta pesquisa tenha sido desenvolvida. Neste sentido refletir sobre minha prática e educação artística na perspectiva de ser mulher despertou um interesse político e artístico, o qual pude constatar que era compartilhado com outras mulheres do campo da música. Tal constatação se deu especialmente no contato com o grupo Sonora: músicas e feminismos, o qual surgiu na Universidade de São Paulo, em 2015, no intuito de visibilizar e dialogar sobre o trabalho artístico de mulheres.

Nesse ambiente, tive um primeiro contato com bibliografias que discutiam relações entre o campo de gênero e da música. Tal estudo se configura em um campo de estudos específico denominado musicologia feminista, que trouxe uma perspectiva metodológica a qual foi trabalhada nesta pesquisa.

A musicologia feminista surge associada a propostas metodológicas presentes no contexto da Nova Musicologia, que propõe a interpretação da música como produto e

\footnotetext{
${ }^{2}$ Dados recolhidos na secretaria de graduação do Departamento de Música da Universidade de São Paulo.
} 
construção cultural, envolvendo questões estéticas e problematizando práticas musicais, no âmbito da recepção e nos processos ideológicos dos discursos.

É importante ressaltar que essas áreas estão vinculadas a campos tais como a antropologia e filosofia. Nesse sentido, é proposta neste trabalho uma metodologia analítica mista, que empresta ferramentas de tais campos a partir da necessidade de cada caso, respeitando suas singularidades e as relações entre eles.

A utilização de uma metodologia mista está ligada à proposta da Nova Musicologia de um aprofundamento no olhar para a música enquanto performance, ou seja, a música não se resume à qualidade de produto, mas pode ser entendida como processo de significado social (cf. PINTO, 2001, p. 227-228). Nesta perspectiva, a música vai além da partitura e gera interesse na análise de gravações, o que provoca - na abordagem musicológica - a possibilidade de aproximação entre a música escrita e não escrita por exemplo. Desta maneira, nesta pesquisa as análises dos materiais, da forma e de aspectos ligados à escrita e à estruturação musical também são realizadas, porém em função da performance.

A partir da perspectiva da música enquanto performance, elementos que no discurso musicológico tradicional seriam considerados "extramusicais" passam a ocupar uma posição central de investigação. Diante disso, as análises neste trabalho têm diferentes materiais como pontos de partida, tais como partituras, gravações em CD, DVD e mídia virtual, depoimentos e entrevistas, espectrogramas, poemas, artigos publicados e diálogos.

Portanto, para tratar do assunto das mulheres que criam com vozes, foram analisados trabalhos - na perspectiva da música enquanto performance - de três artistas ligadas a diferentes práticas criativo-performáticas que trabalham vozes a partir de temáticas relacionadas ao corpo e gênero: Iara Rennó, Jocy de Oliveira e Flora Holderbaum.

A escolha das artistas analisadas está ligada à concepção de pesquisa artística proposta por Kathleen Coessens em seu artigo A arte da pesquisa: Traçando práxis $e$ reflexão (2014). Nesse texto a autora propõe novas maneiras de se realizar pesquisas em 
artes em que perspectivas orientadas pela experiência se mostrem tão importantes quanto perspectivas de orientação teórica, mesclando criatividade e reflexão. A autora aponta que "nenhuma produção de conhecimento nas ciências humanas pode jamais ignorar ou negar o envolvimento de seu autor, enquanto um sujeito humano, em suas próprias circunstâncias" (SAID apud COESSENS, 2014, p. 6).

Nesta abordagem a/o artista-pesquisadora/pesquisador se insere enquanto parte da pesquisa, gerando aproximação entre sujeito e objeto. Esta ideia está ligada à concepção de uma abordagem estética da pesquisa, ${ }^{3}$ que se origina a partir de um "pensamento testemunho" de quem a idealiza, um pensamento a partir de uma experiência, possibilitando uma forma de interação reflexiva entre pesquisadora/pesquisador e objeto de pesquisa (cf. COESSENS, 2014, p. 6).

Nesse sentido, este trabalho se origina a partir de dois tipos de experiência que permeiam minha vida e meu fazer artístico, enquanto compositora, performer e pesquisadora. A primeira delas está ligada a questões feministas e de gênero, que me transpassam enquanto mulher e ser político e dialogam com as circunstâncias atuais, considerando a intensificação do debate sobre gênero no Brasil nos últimos anos e a importância de trazer o assunto para a área da música. A segunda, está no campo da linguagem artística em que estou inserida e diz respeito a minha prática enquanto criadora e performer que encontra na voz lugar privilegiado de pesquisa e tem sido desenvolvida no limiar entre diferentes práticas artísticas.

A perspectiva da pesquisa artística encontra consonância em estudos da Musicologia Feminista, ao considerar a pesquisa em música um fazer não-neutro. A Nova Musicologia - que inclui as epistemologias feministas - opõe-se à pretensão do discurso musicológico tradicional de estabelecer parâmetros universais e hegemônicos na pesquisa em música (cf. PALACIOS, 2013, p. 56). É proposto então um novo foco nas

\footnotetext{
3 “Estética está referida aqui no sentido puro da palavra, 'aesthesis' significando literalmente 'os sentidos', que diz respeito a uma relação experiencial direta" (COESSENS, 2014, p. 6, tradução nossa). Texto original: "Aesthetic is meant here in the pure sense of the word, 'aesthesis' meaning literally 'the senses', concerning a direct experiential relation" (COESSENS, 2014, p. 6).
} 
singularidades de cada caso estudado e no envolvimento de quem pesquisa enquanto sujeito.

Nesse sentido, o repertório a ser analisado neste trabalho foi selecionado por se constituir como referência para o meu próprio trabalho enquanto criadora e performer e por estar inserido em três tipos de práticas artísticas que me movem: a música escrita contemporânea, que dialoga com encenação teatral; a música experimental, que lida com a improvisação; e a canção popular ligada ao rock. A escolha em analisar trabalhos que partem de três diferentes práticas artísticas - e provocar o debate sobre as relações entre as mesmas - reflete uma polifonia de respostas ao terreno ideológico hegemônico, evitando generalizações e relações hierárquicas entre as práticas artísticas.

Em consonância com a perspectiva da pesquisa artística e da Musicologia Feminista, ao longo do estudo foi realizado um laboratório de criação e performance no qual procedimentos e recursos observados nos trabalhos das artistas estudadas foram experimentados e debatidos. Assim, a partir de uma abordagem artística e experiencial, as questões ligadas às maneiras de utilizar a voz em uma perspectiva de gênero foram aprofundadas ao lidar com os objetos de pesquisa também na perspectiva de minha própria manifestação artística, que também compõe o corpus da pesquisa.

Portanto, em uma abordagem feminista da musicologia - como proposto neste trabalho - é essencial que eu me inscreva enquanto autora de corpo presente no texto. Em seu artigo/poemário Parir o pensamento a autora galega Maria Xosé Queizán aponta:

\footnotetext{
... Nestas frases de Platão ${ }^{4}$ comprovamos como são rebaixados os sentidos... O importante é a inteligência abstrata... O Espírito vence a carne, o corpo. Justamente isso, corpo, natureza, é atribuído às mulheres. Frente a isto, o feminismo proclama Direito ao próprio corpo. Recuperar as mãos, o corpo, os sentidos e organizar o mundo a partir deles seria o ponto de partida de qualquer possível mudança (QUEIZÁN, p. 109, 2000, tradução nossa ${ }^{5}$ ).
}

\footnotetext{
${ }^{4}$ A autora refere-se ao texto de Platão: "Se algunha vez podemos saber algo plenamente, debemos estar libres de corpo e contemplar a verdadeira realidade só coa visión da alma... Mentras vivamos, estaremos mais cerca do coñecemento se evitamos, canto nos sexa posible, o intercambio e a comunicación co corpo" (PLATÃO apud QUEIZÁN, 2003, p. 109).

5 “... Nestas frases de Platón comprobamos como son rebaixados os sentidos... O importante é a intelixencia abstracta... O Espirito vence á carne, ao corpo. Xustamente iso, corpo, natureza, é a consideración das mulleres. Frente a isto, o feminismo proclama Dereito ao proprio corpo. Recuperar as mans, o corpo, os
} 
Nesse sentido, afirmar-se enquanto corpo no texto significa refutar a ideia de neutralidade e reafirmar tanto a singularidade de quem escreve, quanto a atividade do corpo no texto, já que o corpo não é passivo e nem deve ser subjugado à mente. Dessa maneira, o gráfico que representa a discrepância na quantidade de ingresso de mulheres e homens no curso de composição da USP, no período especificado, comprova a importância de se pensar o gênero na música, uma vez que o mundo ainda parece ser organizado a partir de discursos hegemônicos que excluem o corpo e a participação ativa das mulheres.

É importante frisar que - assim como relatado também por outras mulheres do campo da composição musical - apesar de eu sempre perceber a diferença numérica entre gêneros neste âmbito, tal questão só passou a ser discutida nos meios que frequento a partir do contato com o grupo Sonora, ou seja, em meados de 2016. Esta constatação é importante para pensar a naturalização com que é vista a exclusão das mulheres nestes espaços. Tal naturalização está ligada à ideia de neutralidade do discurso hegemônico patriarcal. Para a filósofa Judith Butler tal neutralidade relaciona-se justamente com a noção de natureza. Ao tratar especificamente da questão de gênero a filósofa afirma:

... o gênero não está para a cultura como o sexo para a natureza; ele também
é o meio discursivo/cultural pelo qual "a natureza sexuada" ou um "sexo
natural" é produzido e estabelecido como "pré- discursivo", anterior à
cultura, uma superfície politicamente neutra, sobre a qual age a cultura
(BUTLER, 2003, p. 25).

A partir do paradigma cartesiano que privilegia o pensar em detrimento do fazer é estabelecida a hegemonia do neutro, na qual são propagadas generalizações que se manifestam a partir da ideia de uma mente despregada do corpo. Nessa cisão, o sujeito hegemônico que tradicionalmente estabelece as estruturas - masculino, branco e de alta classe social - é desincorporado e é criada uma ilusão de neutralidade.

sentidos e organizar o mundo a partir deles seria o punto de partida de calquera posible mudanza" (QUEIZÁN, 2000, p. 109). 
A noção do "neutro" não apenas favorece os grupos hegemônicos, como gera um agrupamento e catalogação do que é considerado o “outro". Por exemplo, na própria noção binária de masculino/feminino -que perpetua afinal a dissociação entre mente e corpo, relegando a mente aos homens e o corpo às mulheres - são pressupostas características específicas para cada gênero, a fim de fixar estruturas que garantam a ordem simbólica patriarcal.

Portanto neste trabalho se pretende debater a voz e o canto enquanto potências para se organizar o mundo por meio do corpo - como proposto por María Xosé Queizán - e como maneira de superar o discurso da neutralidade, pela perspectiva da singularidade. Nesse sentido é pretendido visibilizar e debater o trabalho artístico de mulheres em atividade, em uma ação de sororidade na perspectiva do feminismo interseccional ${ }^{6}$. Desse modo, assim como no conto La loba - em que uma mulher dá vida a outra se utilizando de sua voz - é proposta uma via de mão dupla entre pesquisadora/artista e artistas analisadas, em um movimento de visibilidade e inscrição dos corpos na pesquisa, que por sua vez estão conectados pela voz.

Para tanto, esta pesquisa é apresentada em quatro capítulos que discutem - a partir da perspectiva do gênero e do corpo - a maneira com que cada artista trabalha as vozes nos casos analisados.

No capítulo 1, são analisadas as 5 Peças para Microvocalidades, de Flora Holderbaum na perspectiva da performance e inscrição do corpo da artista manifestada por sua voz. No capítulo 2, é abordada Ofélia presa nas cordas do piano, trabalho de abertura da ópera As Malibrans de Jocy de Oliveira. A análise é informada na perspectiva do papel das mulheres na ópera e o trabalho vocal enquanto subversão da linguagem. No capítulo 3, foi analisado o disco Arco, de Iara Rennó, a partir da perspectiva da reivindicação pelo corpo que a artista realiza através de sua poética voltada para a sexualidade, manifestada vocalmente no disco. O capítulo 4 traz uma discussão sobre as

\footnotetext{
${ }^{6} \mathrm{O}$ discurso do feminismo interseccional trabalha a ideia de que não existe uma categoria geral das mulheres, já que existem relações de poder e privilégio inclusive entre as mulheres. Neste sentido é proposto uma atenção às singularidades, que envolvem questões de raça, classe, trans-generidade, opção sexual etc. Neste âmbito a sororidade - perspectiva na qual as mulheres fortalecem-se mutuamente - é fundamental, uma vez reconhecidas as singularidades e diferenças nas relações de privilégios.
} 
funções desempenhadas pelas artistas e a maneira de veicular as criações em cada caso estudado, inclusive no laboratório de criação e performance, que se configura no processo Canto para o jardim de veredas, do grupo Teatro Labirinto, ao qual integro como criadora e cantora/atriz.

Apesar de os trabalhos terem sido estudados separadamente - devido às particularidades de cada prática artística abordada - as análises também são de caráter comparativo, uma vez que alguns elementos aparecem em comum nos trabalhos. Tais análises comparativas e ocorrem especialmente no capítulo 4, no qual o assunto das funções e maneiras de veicular as criações foi abordado para discutir os quatro casos, incluindo o laboratório de criação e performance.

Para a produção deste trabalho foi necessário realizar escuta e leitura de diversos materiais além da bibliografia citada nos capítulos da monografia. A relação de artistas de referência está no capítulo 4, já que foram abordadas no processo do Canto para o jardim de veredas, do Teatro Labirinto. No que diz respeito ao material lido, em uma perspectiva de metodologia e formas de organização do trabalho, foram essenciais os textos $\operatorname{Voz} e$ processos criativos em ambientes de ensino-aprendizagem (BRANDÃO, 2015) e A casa represa, a sorte e o corte, ou: A composição musical enquanto imaginação de formas, sonoridades, tempos [e espaços] (BONAFÉ, 2016).

Para aprofundamento na perspectiva do feminismo interseccional e da relação do corpo com movimentos feministas foram lidos os textos Mulheres, raça e classe (DAVIS, 2016) e Nosso corpo nos pertence? Discursos feministas do corpo.(SCAVONE, 2010).

Sobre os assuntos do corpo e voz foram feitas as leituras de quatro textos além da bibliografia citada no decorrer do trabalho: Movimento, Respiração e Canto: a performance do corpo na criação musical (STOROLLI, 2009), Possível Cartografia para um Corpo Vocal Queers em Performance (DORDETE, 2015), The Quest for Voice (GOEHR, 1998) e Demetrio Stratos - em busca da voz-música (HAOULI, 2005).

No campo de intersecção entre musicologia e gênero foram lidos os textos $A$ emergência do campo de música e gênero no Brasil: reflexões iniciais (NOGUEIRA, 
2018) e Cinco Mulheres Compositoras na Música Erudita Brasileira Contemporânea (NEIVA, 2006).

Tais textos listados foram fundamentais nas etapas de realização do projeto e qualificação deste trabalho e também para escrita de artigos de finalização das disciplinas cursadas durante o mestrado. 


\section{CAPÍTULO 1 - O CORPO-VOZ NA MÚSICA: PERFORMANCE E 5 PEÇAS PARA MICROVOCALIDADES, DE FLORA HOLDERBAUM}

\subsection{Performance, performatividade e os estudos da performance}

Em dezembro de 2017, a artista Flora Holderbaum (Florianópolis, 1979) contou um pouco de sua trajetória na série Vozes \#10, proporcionada pelo grupo Sonora: músicas e feminismos. Nessa ocasião a artista falou de seu percurso não unívoco, que envolve as artes plásticas, a poesia e a música. Nessa última área, Flora Holderbaum iniciou os estudos aos 18 anos com o violino e depois se interessou por criações para voz e eletroacústica, e processos de multimídia, nos quais pode unir seus interesses.

A artista discorre sobre sua dificuldade de se fixar nas definições impostas no ramo da prática musical. Nesse sentido ela não se compreende enquanto compositora, intérprete ou improvisadora e finalmente se define enquanto performer. Tal termo encontra consonância com a ampla discussão sobre performance que vem sendo realizada em diversos campos, inclusive na musicologia, tanto no âmbito metodológico, quanto artístico.

As teorias pós-estruturalistas posicionam a noção de performance em uma nova centralidade, muito importante no campo das artes. Em seu livro Performance Studies: an Introduction o teórico Richard Schechner oferece um amplo panorama sobre os estudos da performance. Nesse texto o autor define que é possível estudar qualquer coisa a partir de tal âmbito, uma vez que os Performance Studies se interessam pelo comportamento enquanto objeto de estudo. Nessa perspectiva a performance não se limita ao campo das artes, apesar de encontrar nesse campo espaço privilegiado de estudo.

Os estudos da performance se baseiam em teorias pós-estruturalistas sobre performatividade ${ }^{7}$. Como este trabalho trata de questões de gênero na musicologia, a performance e a performatividade aqui são discutidas a partir de Richard Schechner, em

\footnotetext{
${ }^{7}$ O pós-estruturalismo se localiza na segunda metade do século XX, na França. Porém suas reflexões são aproveitadas nos dias de hoje e muito utilizadas nos trabalhos de Judith Butler e Richard Schechner, discutidos nesta pesquisa.
} 
uma abordagem voltada para a teoria da performance e das artes, e de Judith Butler, que aborda a performatividade também a partir de questões de gênero. De acordo com a filósofa "não há identidade de gênero por trás das expressões do gênero; essa identidade é performativamente constituída, pelas próprias "expressões" tidas como seu resultado (BUTLER, 2003, p. 48).

Judith Butler refuta o paradigma descartiano Penso, logo existo, ao propor que não existe um "ser" antes da ação, ou seja, em sua perspectiva o sujeito se constitui na ação. Nesse sentido o discurso é ação, portanto não existe um sujeito ligado ao âmbito prédiscursivo - ou seja, à natureza -, de modo que o sujeito se dá no discurso, que por sua vez é ação performada, apreendida a partir da repetição das ações performadas no contexto sócio-cultural em que se vive.

Para Butler, a performatividade compreende a identidade do sujeito, que é constituída a partir de ações copiadas de outras ações que são performadas em cada contexto específico $^{8}$. Tais repetições não são idênticas às performances copiadas, uma vez que são realizadas por sujeitos singulares, em novos contextos. De acordo com a autora,

... gênero é um ato que já foi ensaiado, assim como um roteiro sobrevive aos atores específicos que fazem uso dele, mas depende de atores individuais para ser novamente atualizado e reproduzido como realidade. (BUTLER, 2018, p. $11)$.

Tal perspectiva, que considera o sujeito enquanto repetidor de ações performadas, também é trabalhada por Schechner, que define performance enquanto comportamentos restaurados. Trata-se de "ações performadas que as pessoas treinam e ensaiam" (SCHECHNER, 2006, p. 28) por exemplo na infância, preparando-se para a vida adulta. Assim, qualquer hábito, ritual e rotina são comportamentos restaurados.

Apesar de considerar as ações enquanto comportamentos restaurados, Schechner também considera a singularidade de cada ação. Desta maneira,

\footnotetext{
${ }^{8}$ É importante notar que nesta perspectiva não existe uma "ação inicial" a ser copiada, portanto trata-se de “cópia da cópia”. De acordo com Butler: “... o gay é para o hétero não o que uma cópia é para um original, mas, em vez disso, o que uma cópia é para uma cópia”; e ainda: "o original nada mais é do que uma paródia da ideia do natural e do original" (BUTLER, 2003, p. 57).
} 
Performances são feitas de pequenas partes de comportamentos restaurados, mas cada performance é diferente umas das outras. Primeiramente, partes fixas do comportamento podem ser recombinadas em infinitas variações. Em segundo lugar, nenhum evento pode copiar exatamente outro evento. Não apenas o comportamento em si - nuances de humor, tom de voz, linguagem corporal, etc, mas também a ocasião específica e o contexto fazem de cada instância única" (SCHECHNER, 2006, 30, tradução nossa ${ }^{9}$ ).

Richard Schechner se preocupa em diferenciar as definições de performance e performatividade. $\mathrm{O}$ autor trata a performance enquanto comportamentos restaurados, listando oito situações em que ocorre a performance que podem estar separadas ou sobrepostas. São estas:

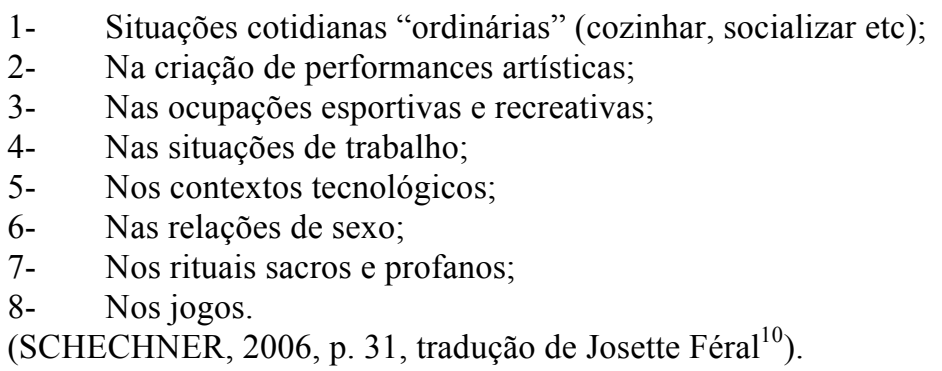

Tais situações não estão encerradas nelas mesmas, mas indicam o "vasto território coberto pela performance" (SCHECHNER, 2006, p. 25). Em seu texto Performance e performatividade: o que são os Performance Studies, Josette Féral analisa o livro de Schechner e escreve sobre a performatividade:

A performatividade, nos diz Schechner, é ao mesmo tempo uma ferramenta teórica e um ponto de vista analítico orientado. Se toda realidade, objeto, acontecimento ou ação podem ser vistos do ponto de vista da performance, isso significa que como performance (as performance), há, portanto, performatividade em todas as coisas. Dito de outro modo, decidir ver em qualquer coisa seu "potencial" performativo, um funcionamento ou um estado

\footnotetext{
9 "Performances are made from bits of restored behavior, but every performance is different from every other. First, fixed bits of behavior can be recombined in endless variations. Second, no event can exactly copy another event. Not only the behavior itself - nuances of mood, tone of voice, body language, and so on, but also the specific occasion and context make each instance unique" (SCHECHNER, 2006, p. 30).

${ }^{10}$ FÉRAL, 2009, P. 151.
} 
que possui possíveis similitudes com a performance correspondente (FÉRAL, 2009, p. 65-66).

Portanto, para Schechner a performance compreende as ações - que são realizadas a partir do comportamento restaurado - e a performatividade se dá na maneira de olhar para a tais ações, a partir da ótica da performance.

Tanto Butler quanto Schechner destacam que a performance e a performatividade se dão na interação entre as pessoas e desta maneira sua singularidade não depende apenas de sua materialidade, mas também de sua interatividade, estando sempre em fluxo. De acordo com Butler, “"mulher' é um termo em processo, um devir, um construir de que não se pode dizer com acerto que tenha uma origem ou um fim. Como uma prática discursiva contínua, o termo está aberto a intervenções e re-significações” (BUTLER, 2003, p. 58).

Se discurso é ação e as ações são repetições de performances de cada contexto em que se vive, o ser "mulher" também é performado e seu conceito varia de acordo com cada cultura e depende de como se dão as interações entre sujeitos que agem/discursam.

Para Schechner a performance está localizada na ação, interação e relação, portanto, nos entremeios. Desta maneira,

... tratar qualquer objeto, trabalho ou produto "como" performance (...) significa
investigar o que tal objeto faz, como interage com outros objetos ou seres, e
como ele se relaciona com outros objetos e seres (SCHECHNER, 2006, p. 30,
tradução noss ${ }^{11}$ ).

Os Performance Studies propostos por Schechner compreendem então que toda ação pode ser estudada como performance, mas não seria em todos os contextos sócioculturais que tal ação é considerada performance. No caso das artes há o campo específico das artes da performance (do que é considerado performance) e também a possibilidade de estudar qualquer trabalho artístico sob a ótica da performance.

\footnotetext{
11 “To treat any object, work, or product 'as' performance - a painting, a novel, a shoe, or anything at all means to investigate what the object does, how it interacts with other objects or beings, and how it relates to other objects or beings" (SCHECHNER, p. 30).
} 
Assim, ao assumir-se performer da voz Flora Holderbaum é alocada no campo da performance, uma vez que trata a voz enquanto materialidade do corpo e trabalha no âmbito das fronteiras. De acordo com Schechner:

\begin{abstract}
Nós tomamos como modelo (sic) as vanguardas históricas e a arte contemporânea que, há muito tempo, colocaram em questão as fronteiras entre as diferentes categorias - as mídias, os gêneros artísticos, as tradições culturais -, misturando-os ousadamente (KRISHENBLATT-GIMBLETT apud SCHECHNER, 2006, p. 3, tradução de Josette Féral ${ }^{12}$ ).
\end{abstract}

Desse modo, ao se considerar performer Flora Holderbaum se posiciona nos "entremeios" e assim encontra seu lugar nas fronteiras.

\title{
1.2. 5 peças para Microvocalidades, Flora Holderbaum ${ }^{13}$
}

(...) a poesia passa por todo o corpo, corpo que se coloca como centro de centenas e milhares de canais sensuais em constante entrada e saída. A inteligência ativa é corpo; o gesto poético é corpo; o corpo, ritmo, e sem ritmo não há linguagem (FONTANA, p. 129, 1992).

É no âmbito da Poesia Sonora - linguagem artística que traz à tona valores expressivos da vocalidade - que a violinista, compositora e performer da voz Flora Holderbaum explora as forças vocálicas da poesia em seu conjunto de peças 5 peças para Microvocalidade, compostas entre 2013 e 2014. Trata-se de cinco micro-comprovisações (Microvoz I, Miniatura vocálica II, Escri3ura, Miniaturas IV e V), cada uma com cerca de um minuto, que giram em torno de experimentações a partir da palavra escritura.

Neste trabalho é proposta uma discussão sobre o aspecto do corpo/voz enquanto materialidade da performance no âmbito da Poesia Sonora, a partir da análise do conjunto 5 peças para Microvocalidades. A análise é conferida a partir da escuta da peça, leitura de artigo da autora sobre a mesma, visualização de espectrogramas e conversas com a artista.

\footnotetext{
${ }^{12}$ FÉRAL, 2009, p. 53.

${ }^{13} 5$ peças para vocalidades mínimas ou microvocalidades: https://soundcloud.com/floraholderbaum/sets/5-pe-as-para-vocalidades-m
} 


\subsection{Corpo, vocalidade e a Poesia Sonora}

Uma voz significa isso: existe uma pessoa viva, garganta, tórax, sentimentos, que pressiona no ar essa voz diferente de todas as outras vozes. Uma voz põe em jogo a úvula, a saliva, a infância, a pátina da existência vivida, as intenções da mente, o prazer de dar uma forma própria às ondas sonoras (Ítalo Calvino, Um rei à escuta, p. 48). ${ }^{14}$

Se tomamos a perspectiva da voz enquanto materialidade do corpo, podemos observar que a Poesia Sonora é uma linguagem artística que traz à tona valores expressivos da vocalidade ${ }^{15}$. Ao utilizar-se de recursos tais como desmembramentos das palavras, onomatopeias, aliterações etc - combinados com recursos eletrônicos -, a Poesia Sonora provoca um deslocamento do foco semântico das palavras para a musicalidade inerente à língua e a corporeidade de quem está performando.

Desenvolvida inicialmente na Europa a partir da segunda metade do século XX, a Poesia Sonora surge em resposta à hegemonia da escrita, a partir de um "desejo do retorno ao oral, no âmbito dos poetas; desejo de retorno ao falado, no âmbito dos músicos" (ZUMTHOR, 1992, p. 139). Nesse âmbito, que tem como tendência o cancelamento das fronteiras entre as artes, emerge a urgência de desestabilizar artisticamente o que já era determinado, "desneutralizar o neutro". Ou seja, pode-se dizer que ocorre a desestruturação das palavras - campo tão conhecido e valorizado na cultura ocidental através da vocalidade, como um grito da corporeidade em detrimento da semântica.

Assim a língua é deslocada de seu lugar estabelecido como divino e universal para o lugar do corpo, que através da Poesia Sonora se utiliza da metáfora da linguagem para comunicar - para além do sentido semântico - sua existência singular no mundo. De acordo com Zumthor:

... o corpo respira, trabalha, sofre e morre, coisa que nenhum signo jamais fez. A Poesia Sonora, situando-se desde o início sobre um plano distinto da textualidade, reivindica-se de pertencer à ordem daquilo que respira, trabalha $\mathrm{e}$ morre (ZUMTHOR, 1992, p. 141).

\footnotetext{
${ }^{14}$ CALVINO, Italo. Sob o sol-jaguar. Trad.: Nilson Moulin. São Paulo: Companhia das letras, 1995.

${ }^{15} \mathrm{O}$ termo "vocalidade" refere-se ao que é característico da voz e anterior à palavra, ao sentido semântico. Tal perspectiva é discutida mais a fundo no capítulo $A$ voz na subversão do arquétipo: Ofélia presa nas cordas do piano, de Jocy de Oliveira.
} 
A corporeidade de quem performa no âmbito da Poesia Sonora extrapola seus limites físicos através da utilização de tecnologia eletrônica. Nesse sentido não é necessário que o corpo esteja fisicamente presente para ser percebido e se inscrever no espaço, uma vez que:

\begin{abstract}
A voz emana do corpo total e a ela nos reconduz: corpus et spiritus, como escreve ainda Giovanni Fontana, ambíguo sopro, espécie de grito primigênio, sonoridade destinada a extinguir-se com o ultimo respiro, identificada por um gesto do corpo, pelo gesto mais simples e radical: o de viver. (...) O corpo não é somente um agregado de membros que gesticulam sob nossos olhos: é, mais profundamente, a intensidade do gesto interior, repentinamente manifestado na plenitude da voz. (ZUMTHOR, 1992, p. 141-142).
\end{abstract}

Portanto, no âmbito da Poesia Sonora, o corpo, mesmo que virtualmente, tem sua presença conferida através da voz, que - inclusive por meio de gravação - comunica o corpo que a emite, abarcando desde seus gestos interiores a questões identitárias (como marcas de gênero).

A voz é experimentada então não apenas na esfera acústica, mas também por meio de processamentos eletrônicos. Nessa perspectiva é possível - através da amplificação por meios tecnológicos - a exploração de sons mínimos da boca e do corpo e é nesse âmbito que Flora Holderbaum desenvolve seu trabalho 5 peças para Microvocalidades.

\title{
1.4. Poema Poço B'arthesiano ou "onda do estylo ga(I)go" e a Microvoz 1
}

Poço B'arthesiano ou "onda do estylo ga(l)go"

Como nomear essa linha de crista em direção à qual toda

a língua se tenciona, modulante?

Gilles Deleuze

Da crista da língua ao vale da palavra

Pálida palavra!

Que veloz-mente cai e Crista-liza

$O$ estrelado estriado

Vale

Da ex-crista

(v-b)ale 'ada

Com-valida

Com-valha 


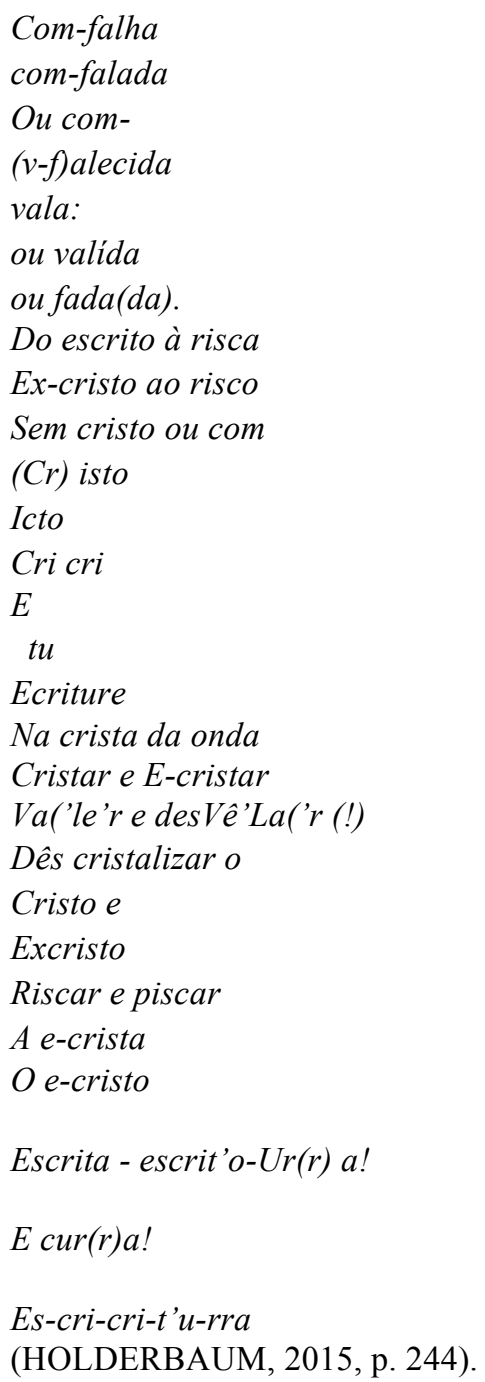

Para a criação de 5 peças para Microvocalidades Flora Holderbaum parte dos conceitos de escritura de Roland Barthes e de Gilles Deleuze, e dos conceitos de língua menor e gagueira da língua de Deleuze e Felix Guattari. A partir da frase de Deleuze contida no poema ${ }^{16}$, a artista escreve em 2013 o Poço B'arthesiano ou "onda do estylo

\footnotetext{
${ }^{16}$ DELEUZE, Gilles. Uma nova estilística. Prefácio. In: PASSERONE, Giorgio. La Linea astratta:
} Pragmatica dello stile. Milano, Guerini Studio, 1991, pp. 9-13. 
ga(l)go”, que por sua vez dá origem inicialmente a uma peça com o mesmo nome e depois, retrabalhada a partir da ideia de microsons, resulta nas 5 peças para Microvocalidades.

O poema já traz em sua escritura recursos de figura de linguagem que são reaproveitados na performance, tais quais aliterações, paronomásias, desmembramentos, permutações de palavras etc. Os recursos são utilizados no poema tais como zooms nas palavras e em sua semântica, que chamam a atenção do leitor para cada recorte estabelecido. São explorados os desdobramentos mínimos de cada palavra. Ora as palavras se repetem - porém com uma letra ou outra modificada, que pode mudar seu sentido - ora cada trecho da palavra é repetido, ou frisado pela utilização de letras maiúsculas e sinais de pontuação, tais como parênteses, barras, hífens etc.

A escritura do poema afinal busca alocar-se no espaço entre "a crista da língua e o vale da palavra", passeando entre corpo e semântica. Dessa forma, a ideia do grão e utilização de sons mínimos surgem antes dos recursos eletrônicos na peça. A leitura do poema gravada em estúdio foi feita, de acordo com a artista, através de experimentações da sonoridade da escritura das letras e repetições de gagueira das palavras do poema (HOLDERBAUM, 2015, p. 242).

Figura 2 - Espectrograma da Microvoz I (HOLDERBAUM, 2016). 


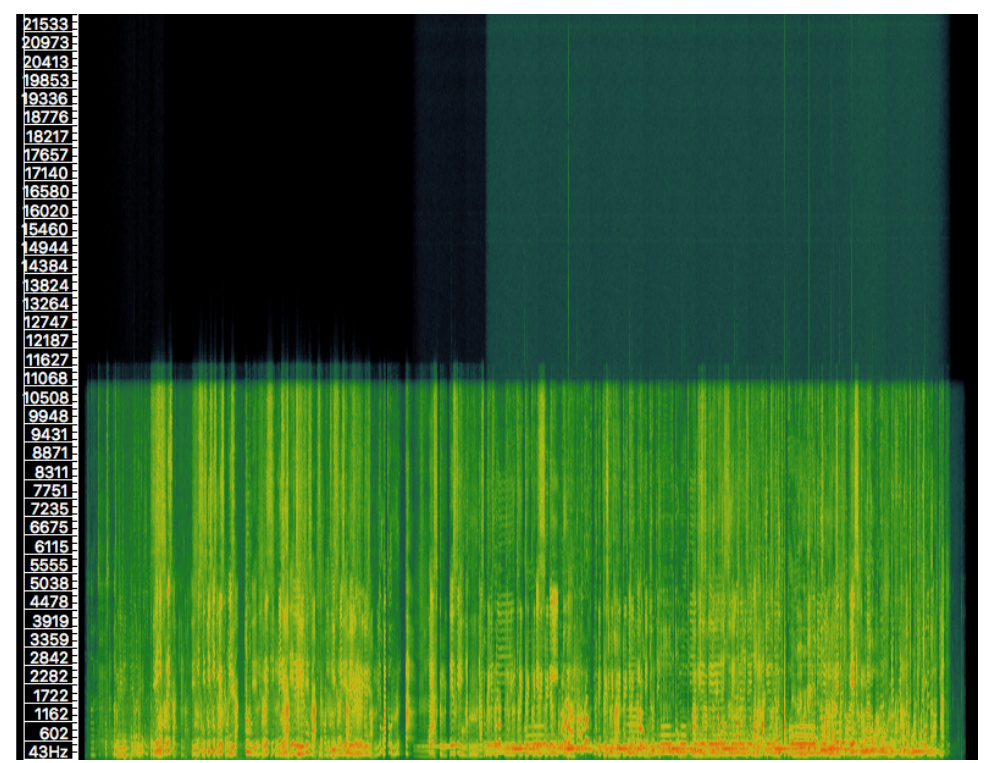

Fonte: software Sonic Visualizer.

Ao estabelecerem expressões da vocalidade mínima, os recursos utilizados para trabalhar a voz - tanto acústicos quanto eletrônicos - definem as formas das pequenas peças. Por exemplo, a Microvoz I pode ser dividida em duas seções. Tais seções têm seus finais marcados pelo fonema /a/, último fonema da palavra "escritura". Como pode ser visto no espectrograma, na primeira metade da peça - que chamaremos de parte $\mathrm{A}$ - são utilizados sons com frequências abaixo de $12 \mathrm{k}$ Hertz.

Iniciada com um fade in e adensamento da textura, na parte A são explorados sons desmembrados da palavra escritura, que também passeiam pelas palavras risca e isto. Trata-se de várias vozes sobrepostas e espacializadas, que têm como textura predominante o som granulado, cuja fonte varia entre a síntese granular da voz, explorações de cacofonias e possibilidades sonoras do fonema $/ \mathrm{r} /$.

Na parte B da peça surge um som contínuo, que através de efeito ocupa todo o espectro demarcado pelo espectrograma, inclusive as faixas de frequência acima de $12 \mathrm{kHz}$. Esse som forma uma espécie de acorde de harmônicos, que serve de cama para as explorações da palavra escritura, que continuam. Como demonstrado no espectrograma por meio de linhas horizontais, nessa parte a artista ainda brinca com sons longos a partir de vogais, que são modulados em síntese granular, e/ou pelas interferências do /r/. 
É interessante notar que a partir da exploração da sonoridade da escritura ("escri cri tura" ${ }^{, 17}$ ) das letras, combinada à vocalidade mínima, a artista brinca com as fronteiras: onde inicia uma prática de linguagem e termina outra? Ou seja, onde se termina a escrita e se inicia a vocalidade? Onde termina a voz acústica e começa a voz processada eletronicamente? Ao trabalhar nessas fronteiras, tendo a voz como fio condutor, Flora "estende as reverberações, rastreia as transformações e direcionalidades entre o timbre vocal e outros timbres, tempos e sonoridades próprios da manipulação eletrônica" (HOLDERBAUM, 2015, p. 242).

No processo de busca por "um material sonoro das forças vocálicas da poesia" a artista cria um "complexo sonoro, textural e gestual entre a fala, a poesia, os sons do corpo e sons eletronicamente manipulados" (HOLDERBAUM, 2015, p. 242).

\subsection{Vocalidades mínimas, ou Microvocalidades, os grãos e os materiais}

Figura 3 - Imagem utilizada no Soundcloud de Flora Holderbaum, em 5 peças para Microvocalidades

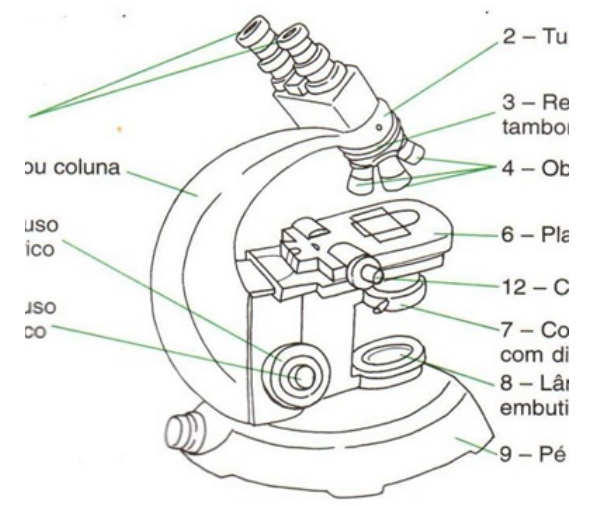

Fonte: https://soundcloud.com/flora-holderbaum

O caráter microscópico do conjunto 5 peças para Microvocalidades se dá em vários níveis. Ele está presente nos recursos utilizados na construção das peças, na maneira de trabalhá-los e na forma de micropeças em que o conjunto é apresentado.

Em artigo para a revista Vórtex, Flora Holderbaum comenta que o conjunto de peças surgiu a partir de "questionamentos de como rastrear ou traçar vocalidades num

${ }^{17}$ (HOLDERBAUM, 2015, p. 242). 
nível micro sonoro. Como pensar, cantar e tocar um grão sonoro como um traço de vocalidade?". A partir desse questionamento a artista estabelece o "grão" como seu campo de exploração criativa, que se traduz em seu trabalho na utilização de recursos de síntese granular.

A síntese granular parte do princípio de que qualquer som, mesmo que seja contínuo, pode ser representado por um grande conjunto de partículas sonoras dispostas no tempo: os grãos sonoros. De acordo com Fernando Iazzetta:

\footnotetext{
Essas partículas são extremamente curtas (em geral entre 1 milésimo e 1 décimo de segundo). Um número suficiente desses grãos podem ser agrupados em "nuvens" para formar um evento sonoro. Pode-se fazer uma analogia entre a geração de um som por síntese granular e um jato de tinta spray, onde cada ponto de tinta corresponderia a um grão de som (IAZZETTA ${ }^{18}$ ).
}

Utilizada como recurso eletroacústico, a síntese granular cria grãos sonoros que podem ser trabalhados independentemente. No caso de 5 peças para Microvocalidades, Flora realiza procedimentos de micro edição a partir dos grãos e das texturas geradas. A partir de um grão sonoro, por exemplo, ela desenvolve uma nova textura, ou gera um som granular a partir de repetições de um grão. Estes recursos são utilizados em busca de explorar "vestígios de uma vocalidade mínima antes e depois da linguagem" (HOLDERBAUM, 2015, p. 242).

$\mathrm{Na}$ execução do conjunto de peças esta busca por traços de vocalidade se traduz em uma extrema corporeidade do som, através de recursos como "aliterações, paronomásias, processos de reversão das palavras, repetição intensa, ritmos aditivos ou subtrativos, exercícios de respiração, movimentos de corpo, diferentes ânimos ou estados emocionais etc" (HOLDERBAUM, 2015, p. 242). Podemos ouvir a língua da artista, perceber sua garganta de carne, seu corpo único que emite sua voz singular.

Tais recursos são distribuídos nas micropeças, sendo trabalhos de acordo com os materiais escolhidos para cada uma. Nas Miniaturas $I V$ e $V$, por exemplo, são explorados

\footnotetext{
${ }^{18}$ Fonte: $\underline{\text { http://www2.eca.usp.br/prof/iazzetta/tutor/audio/sintese/6-granular.html }}$
} 
amplamente diferentes ânimos. A partir da fala e canto da artista são desdobradas risadas, choro, gritos etc.

Enquanto em cada uma das outras micropeças foram escolhidos alguns desses recursos a serem explorados, na Escri3ura há um aglomerado de materiais, que aparecem em camadas, como demonstra o gráfico:

Figura 4 - Gráfico de camadas da micropeça Escri3ura (HOLDERBAUM, 2016). 

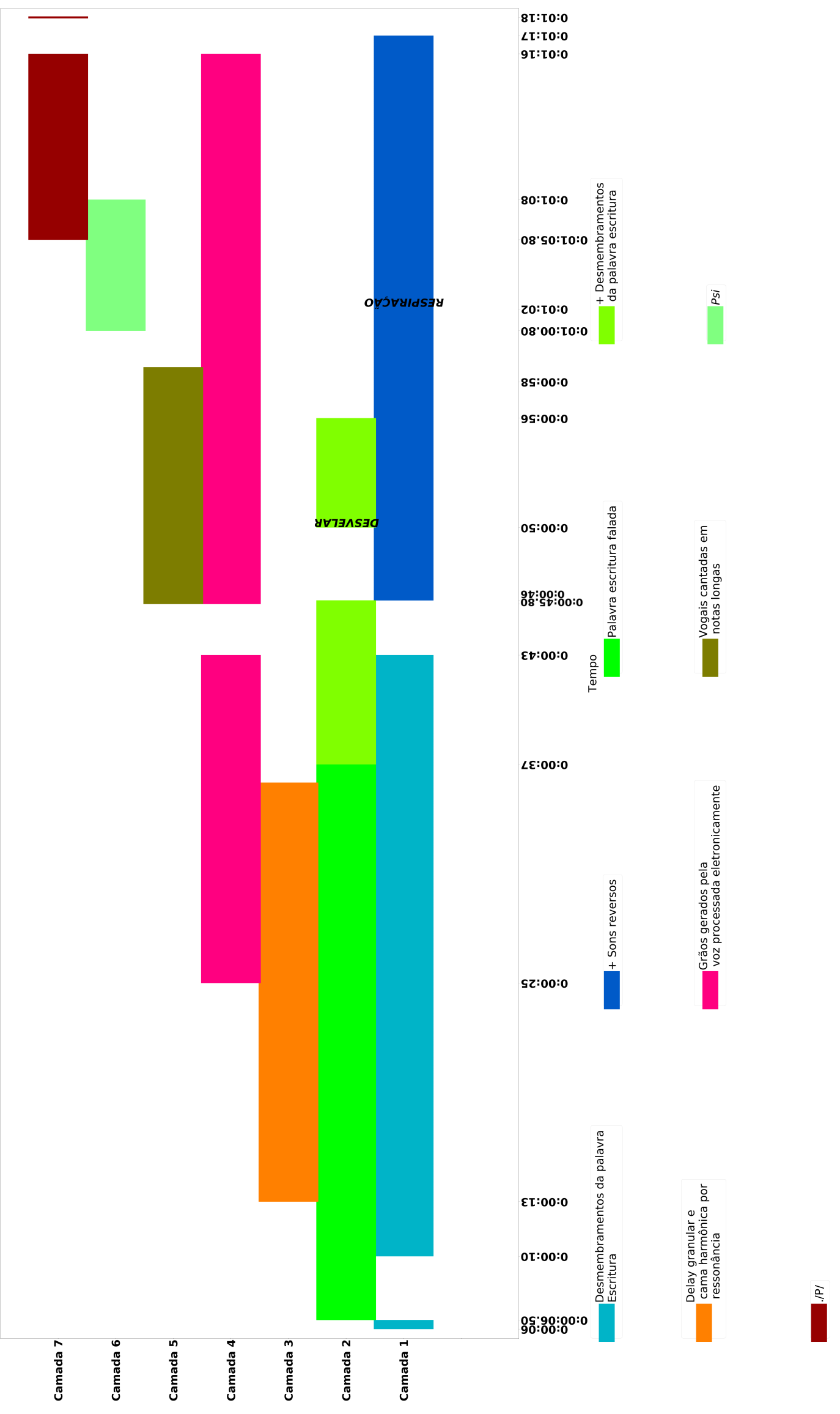
Fonte: gráfico produzido para este trabalho.

As camadas se interpenetram por meio de recursos de dinâmica e espacialização, que são gerados tanto eletronicamente, quanto no espaço físico. Flora Holderbaum conta que se movimentou "de diversos modos na sala de gravação, para gerar espacializações" (HOLDERBAUM, 2015, p. 242). As camadas 1 e 2 utilizam praticamente os mesmos materiais, porém pode ser percebido que a camada 2 é a que fica a maior parte do tempo em destaque, com maior volume e mais centralizada espacialmente.

Portanto em Escri3ura as camadas formadas por diferentes materiais utilizados geram um complexo sonoro textural e gestual entre a fala e a poesia, os sons do corpo, que é manipulado tanto eletronicamente, quanto no espaço físico.

\subsection{Grãos sonoros e grão da voz: mais um espaço criado}

Ao tratar da ideia de grão e a corporeidade conferida pelos recursos utilizados por Flora Holderbaum, não podemos deixar de traçar relações entre os grãos sonoros explorados vocalmente pela artista e o grão da voz, conceito de Roland Barthes. O autor chama de grão da voz a relação que existe entre a língua e a voz, ou seja, o espaço onde elas se encontram. É por intermédio do grão da voz que o corpo de quem performa se faz presente, já que o grão se dá na voluptuosidade dos sons significantes de quem canta. $\mathrm{O}$ corpo, a língua e a garganta podem então ser materializados nos espaços que germinam os significados. De acordo com o autor, "O grão seria isso: a materialidade do corpo falando sua língua materna" (BARTHES, 1986, p. 265).

O grão da voz, para Barthes, se dá na fricção entre a música e a língua, que neste caso não se refere ao sentido semântico da linguagem, mas à materialidade do corpo que canta. Nesse sentido, o grão - definido pelo autor também como "o corpo na voz que canta” - está ligado ao prazer, à corporeidade e escapa da hegemonia da semântica (BARTHES, 1986, p. 268- 270).

Em 5 peças para Microvocalidades Flora Holderbaum explora tal perspectiva ao trabalhar os fonemas de maneira a não apenas reproduzi-los, mas carregando-os de 
significados expressivos. Por exemplo, tanto na Microvoz 1, quanto na Miniatura Vocálica II o fonema /a/ aparece várias vezes, ora aspirado, ora falado, ora com as duas intenções misturadas, ora processadas eletroacusticamente, ora não. Em vários momentos tais utilizações do fonema dão uma sensação de satisfação, gozo e conferem sensualidade à peça. Dessa maneira, os fonemas são carregados de sentido, não pela semântica, já que inicialmente a letra "a" sozinha nada significa, mas de sentido que remete ao corpóreo, às sensações.

A partir da discussão sobre o conceito de grão da voz e da síntese granular proponho um retorno ao questionamento: "Como pensar, cantar e tocar um grão sonoro como um traço de vocalidade?". Se considerarmos que o traço de vocalidade está então intimamente ligado ao grão da voz, podemos reformular o questionamento da artista da seguinte maneira: o que intrínseco ao grão da voz cabe em um grão sonoro?

\subsection{Traços de vocalidade nas ressonâncias por extensão}

A exploração pelos traços de vocalidade também se dá a partir da utilização de reverberações e rastreamento de ressonâncias. Assim, na Miniatura Vocálica II, por exemplo, a artista utiliza sons gravados a partir da "entoação da voz dentro da cauda de um piano, com o pedal de ressonância abaixado, obtendo uma ambiência toda particular, anasalada e cheia de harmônicos" (HOLDERBAUM, 2015, p. 242) ${ }^{19}$.

Nesta micropeça são exploradas apenas as vogais da palavra escritura ([e], [i], $[\mathrm{u}]$ ), acrescido do fonema $[\mathrm{y}]$ (" $u$ francês") e a consoante "s".

\footnotetext{
${ }^{19}$ Em conversa com a artista, Flora Holderbaum me contou que enquanto cantava dentro do piano, sua amiga Lilian Nakahodo a ajudou, apertando o pedal de sustentação.
} 
Figura 5 - Espectrograma da Miniatura Vocálica II (HOLDERBAUM, 2016)

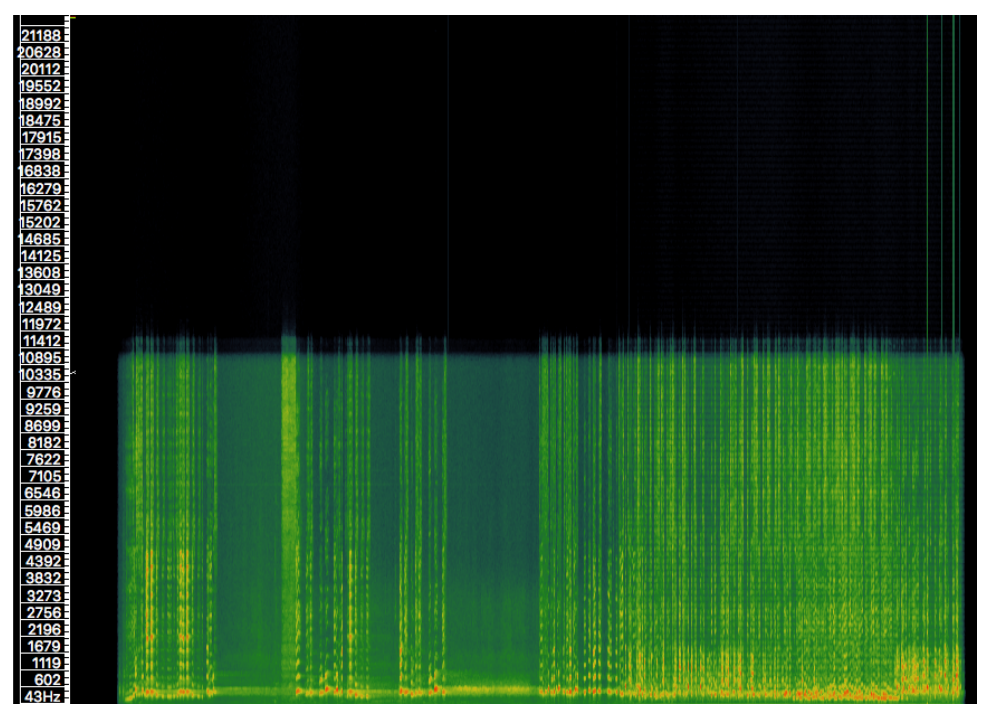

Fonte: software Sonic Visualizer.

Como podemos conferir no espectrograma, a peça se inicia com sons curtos granulares, que são tanto processados eletroacusticamente, quanto não. Tais sons exploram diferentes dinâmicas e em seguida há um momento de ressonância. Tal padrão é repetido três vezes, sendo que cada momento de sons curtos e suas ressonâncias acontecem em espaços de tempo diferentes. Ao final da peça os sons granulares são intensificados e cada vez mais processados eletroacusticamente, gerando uma maquinação da voz, que é somada à ressonância.

Desta maneira a discussão sobre o traço de vocalidade transcende inclusive o tempo em que a voz se dá. Mais uma questão pode ser levantada: o quão possível é reconhecer tal traço vocal na ressonância por extensão criada a partir de outro instrumento e modificada eletroacusticamente?

Nas Miniaturas IV e $V$ também se dá a ressonância por extensão por meio de um agente acústico externo. Nessas micropeças Flora Holderbaum gravou próxima a uma caixa clara com a esteira aberta, explorando sons que ressoam com tal instrumento. Assim, a voz faz vibrar a caixa criando um efeito que, diferentemente do caso do piano, se dá no 
momento em que a artista canta notas específicas. Portanto no início dessa peça são exploradas tais notas, provocando uma modulação na voz.

\subsection{Considerações finais}

As 5 peças para Microvocalidades trazem à tona a discussão sobre a maneira com que os limites entre a escrita e a corporeidade podem estar presentes dentro de um som mínimo, dentro de um grão. As práticas de linguagem são abordadas a partir da escritura, que passa do poema escrito para o corpo em via de mão dupla, por meio de recursos que exploram sons mínimos vocais granulados acusticamente e eletronicamente.

A peça é trabalhada então a partir da metáfora da utilização de um microscópio. Tanto os grãos, quanto o trabalho entre fronteiras, se dão em vários níveis e, à medida em que damos um maior zoom, identificamos mais um grão, mais uma fronteira explorada. A própria experimentação da palavra escritura no conjunto de peças aparece como um dos níveis em que as fronteiras são discutidas, à medida em que essa palavra significa o modo em que se apresenta o texto, podendo passear entre as práticas de linguagem.

Ao alocar-se nas fronteiras, as 5 peças para Microvocalidades são estabelecidas no campo das artes performáticas. O campo da performance também pode ser abordado a partir de diferentes zooms, como discutido no início do capítulo. As artes performáticas, bem como as teorias feministas, encontram consonância com as teorias de performatividade pós-estruturalistas. Richard Schechner inclusive aponta em seu livro a relação entre o surgimento das Performance arts nos Estados Unidos e movimentos feministas. Tais pontos de vista encontram consonância na perspectiva pós-estruturalista que define a identidade como construída histórica e politicamente e não fixada pela justificativa da ideia de natureza.

O autor destaca o slogan "o pessoal é político" como marca da relação entre os movimentos feministas e as artes da performance. Na década de 60 nos movimentos feministas surgiu a ideia de que "até os eventos mais pessoais, quando profundamente 
compreendidos e analisados, mostram como a sociedade é organizada de maneira a desempoderar as mulheres" (SCHECHNER, 2006, p. 158, tradução nossa ${ }^{20}$ ).

Tal perspectiva foi explorada por artistas feministas, que buscavam trazer a arte para o pessoal e corpóreo, destacando a singularidade de cada momento e corpo, e sua relação com o público. Dessa maneira Schechner afirma que:

... diferentemente do teatro, dança e música, a maioria das artes da performance era e é o trabalho de artistas individuais utilizando-se a si mesmos - corpos, psiques, anotações, experiências - como material (SCHECHNER, 2006, p. 162, tradução nossa ${ }^{21}$ ).

Nessa perspectiva, o corpo - como materialidade da ação que nos faz sujeitos - é posicionado em uma nova centralidade e a voz emerge como marca sonora deste corpo. A Poesia Sonora é manifestada, portanto, como um importante grito da corporeidade em detrimento da hegemonia da semântica. Nesse sentido, mesmo não tratando da temática de gênero em 5 peças para Microvocalidades, Flora Holderbaum trabalha sua corporeidade utilizando a voz, que se inscreve enquanto marca de gênero no contexto sócio-cultural em que está inserida.

No caso de 5 peças para Microvocalidades, a performance é comunicada em meio virtual, no qual o corpo se faz presente através da voz e é criado um espaço de "emanação da própria matéria de que somos feitos" (ZUMTHOR, 1992, p. 144).

Portanto, em 5 peças para Microvocalidades, Flora Holderbaum parte da palavra e a destrincha, como se mostrasse o corpo presente na emissão das palavras. Nesse processo seu corpo é evidenciado e a cada zoom nos sons mínimos emitidos por sua voz são descobertas suas singularidades, inclusive no que diz respeito às marcas de gênero.

\footnotetext{
20 “... even the most personal situations, when fully understood and analyzed, show how society is organized in ways that disempower women" (SCHECHNER, 2006, p. 158).

21 “... unlike theater, dance, and music, much performance art was and is the work of individual artists using their own selves - bodies, psyches, notebooks, experiences - as material” (SCHECHNER, p. 162).
} 


\section{CAPÍTULO 2 - VOZ E SUBVERSÃO DA LINGUAGEM DA ÓPERA: OFÉLIA PRESA NAS CORDAS DO PIANO, DE JOCY DE OLIVEIRA}

\subsection{Ofélia presa nas cordas do piano, de Jocy de Oliveira: subversão dos arquétipos e a morte das mulheres na ópera ${ }^{22}$}

No ano 2000 Jocy de Oliveira - compositora, pianista, professora e escritora, nascida em Curitiba, 1936 - estreou sua ópera As Malibrans, uma compilação de peças reunidas através de recursos multimídia, cujo fio condutor é a vida da diva Maria Malibran $^{23}$. Personagens femininas de mitos e peças servem de arquétipo para trajetória da diva franco-espanhola.

Ofélia presa nas cordas do piano é a primeira peça após o prólogo da ópera no registro em DVD da apresentação realizada no Teatro Municipal do Rio de Janeiro em 2000 - utilizado aqui como suporte para análise, junto à partitura. A peça é interpretada pelas artistas Kátia Guedes e Gabriela Gerluda ${ }^{24}$.

A ópera, de acordo com Jocy de Oliveira,

... enfatiza o lado escuro da 'diva', sua voz e seu papel como personagem operístico. Na grande maioria dos libretos tradicionais a personagem feminina é sempre destinada à submissão ou condenada à morte. Através da história da ópera e também na vida real, estas "divas", com suas divinas vozes, tornaramse deusas no imaginário do público e foram, muitas vezes, levadas à insanidade (OLIVEIRA, 2000, p. $12^{25}$ ).

Em seu livro A ópera ou a derrota das mulheres Catherine Clément analisa os papéis das mulheres nas óperas, desde as personagens, às divas e às espectadoras. A autora enfatiza os destinos violentos das personagens, assim como o caráter de "adorno" relegado às mulheres neste universo. De acordo com a autora:

\footnotetext{
${ }^{22}$ Ofélia presa nas cordas do piano: https://play.spotify.com/album/7N33HP3zah1jrNAZUhkTrB/2moTeI2aSKviUEKbCXJFN1

${ }^{23}$ Maria Malibran foi uma mezzo-soprano franco- espanhola, de enorme prestígio durante sua carreira no século XIX. Morreu jovem, aos 28 anos e tornou-se legendária por sua voz e sua personalidade marcante. ${ }^{24}$ Apesar de na partitura escrita a peça ser caracterizada como um solo, nesta performance há um desdobramento da personagem, no qual próximo à metade da peça, surge no palco uma segunda atriz (Gabriela Gerluda) vestida e maquiada exatamente como a primeira (Katia Guedes). A segunda atriz complementa, contrapõe ou repete as ações e cantos da primeira.

${ }^{25}$ Texto sobre As Malibrans, presente no encarte do DVD da ópera.
} 
As mulheres (...) são o enfeite, o ornamento indispensável a todas as festas. E elas cantam. Mais do que isso, elas ocupam a cena: sem cantora não há ópera. Mas o papel de enfeite, de objeto decorativo não é o principal papel; e as mulheres no palco da ópera cantam invariavelmente sua eterna derrota (CLEMENT, 1996, p. 12).

No que diz respeito às divas cantoras de ópera, Catherine Clément discorre sobre a desencarnação relegada a elas, uma vez que são vistas apenas enquanto vozes desincorporadas, já que suas carreiras comumente as impedem de desfrutar de uma vida pessoal, acarretando em insanidade e até na morte. Para exemplificar a autora mostra como frequentemente as cantoras de ópera adotam nomes artísticos estrangeiros, como é o caso de Maria Malibran. Para a autora "As estrangeiras são necessárias para assumir a estranheza de mulheres que não são completamente mulheres, são manequins desencarnados, que só têm vida na voz" (CLÉMENT, 1996, p. 45).

Sobre Maria Malibran, Jocy de Oliveira assinala:

Sua extraordinária vida combina toda a magnitude triunfal de uma carreira que a consagrou como a diva de seu tempo ao sofrimento e angústia que este papel perpetua. Foi a bela musa de seu tempo (...) e foi levada à morte assim como muitas outras primadonnas, usadas pela sociedade e sacrificadas pelo seu perfil de diva (OLIVEIRA, 2000, p. 12).

Assim, no universo tradicional da ópera as mulheres, apesar de encarnarem papel central, representam - tanto no nível das personagens, quanto da vida real - valores que perpetuam o patriarcado e contribuem na demarcação de lugares tradicionalmente atribuídos às mulheres.

Afinal a ópera carrega valores culturais - que incluem os arquétipos literáriomitológicos - produzidos historicamente pelos grupos hegemônicos que geram uma situação de marginalização, na qual tais postulados são afinal criados por e para a manutenção da hegemonia masculina, branca e de alta classe social.

Os mitos e os arquétipos são uma importante ferramenta tanto de manutenção de tal hegemonia, quanto de sua subversão. Por exemplo, para a autora galega María Xosé Queizán deve ser trabalhada uma contramitologia. Ela afirma que "A literatura feminista 
tem que ser incompatível com os mitos herdados" (QUEIZÁN, 2000, p. 106, tradução $\left.\operatorname{nossa}^{26}\right)$.

Tais arquétipos - presentes em mitologias e na literatura tradicional - dão suporte ao que é considerado feminino no imaginário ocidental. Portanto são criados modelos da figura feminina instituídos de acordo com os valores que reforçam a hegemonia masculina e o patriarcado.

Figura 6 - Ophelia, John Everett Millais, 1851-52.

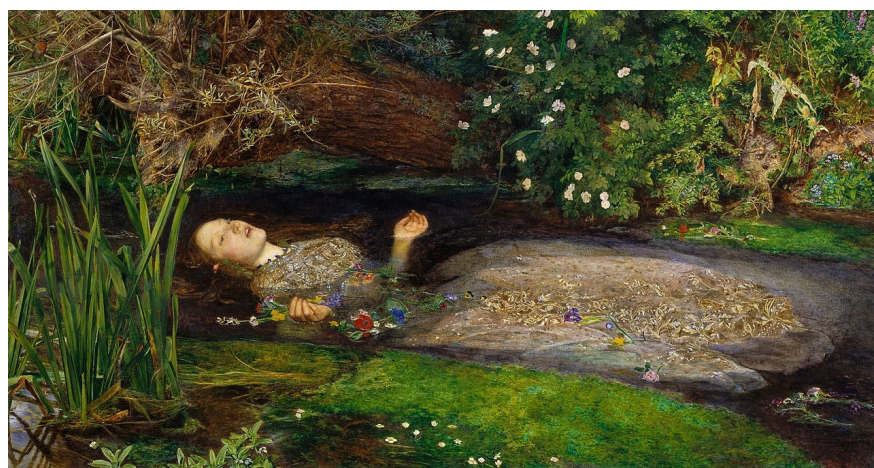

Fonte: https://www.abc.net.au/news/2018-09-06/pre-raphaelite-paintings-from-tate-to-australia-for-first$\underline{\text { time } / 10188858}$

Por exemplo, o quadro Ophelia de Millais, retrata, de acordo com Bram Dijkstra, o "culto à invalidez" referente a um modelo ideal da figura feminina no século XIX (DJIKSTRA, 1986, p. 25).

A partir do século XIX a personagem de Ofélia - até então pouco comentada por teóricos da literatura - foi retomada e popularizada por pintores que destacaram a partir de Ofélia uma imagem do ideal do sacrifício feminino. De acordo com Djkstra:

[Ofélia foi] ... o exemplo favorito no século XIX da mulher enlouquecida de amor e auto-sacrificial que demonstrou perfeitamente sua devoção ao seu homem, sucumbindo à loucura, que se cercou de flores para mostrar sua equivalência a elas e ao final entregou-se a um túmulo nas águas, cumprindo as fantasias mais profundas do sexo masculino do século XIX sobre a dependência feminina (DJKSTRA, 1986, p. 42, tradução nossa ${ }^{27}$ ).

\footnotetext{
26 “A literatura feminista ten que ser incompatible cos mitos herdados" (QUEIZÁN, 2000, p. 106).

27 “... the later nineteenth-century's all-time favorite example of the love-crazed self-sacrificial woman who most perfectly demonstrated her devotion to her man by descending into madness, who surrounded herself with flowers to show her equivalence to them, and who in the end committer
} 
A pintura caracteriza a personagem como uma bela mulher sem qualquer controle sob seu destino, que é conduzida pela morte através das águas, como se fosse mera parte da paisagem. Seu corpo passivo é retratado com beleza e, coberto pelas roupas e flores, é condenado à eterna ausência (PERNI, 2008, p. 28).

Neste contexto, em sua peça Ofélia presa nas cordas do piano, a compositora Jocy de Oliveira propõe uma outra perspectiva sobre a personagem canônica que, pelo uso de sua voz e performance, não parece responder ao desejo masculino, mas se posiciona em uma nova centralidade.

Em contraposição à personagem idealizada no imaginário romântico, a Ofélia retratada por Jocy de Oliveira possui características que a conduzem para um papel central. Essa Ofélia não existe em função de Hamlet ou do desejo mórbido masculino. Ao passo que se estabelece enquanto arquétipo da diva, a personagem está centrada em si mesma, considerando que ao retratar a realidade das divas, retrata a sua própria.

No vídeo de Ofélia presa nas cordas do piano a personagem aparece com um belo vestido, uma peruca de cabelos longos e negros e uma maquiagem mórbida, que parece aproximar sua figura à de uma boneca, com os olhos com grandes contornos cinzas, a testa amarela e um batom em estilo boca de boneca. Já louca e próxima da morte, ela canta palavras sem sentido. Essa versão de Ofélia não tem o intuito de gerar prazer ao público, ao contrário, ela explicita seu lado mais obscuro e a perversidade a que são submetidas as mulheres que carregam o fardo do modelo ideal feminino, assim como as divas, que também são muitas vezes levadas à loucura e à morte.

Na tradição do universo da ópera, os destinos de Ofélia e Maria Malibran se cruzam na perversidade que carregam enquanto modelo ideal. Elas cantam e elas morrem. De acordo com Catherine Clément: “A ópera, os fósforos ou a pequena sereia, que corta a língua para viver ao lado do homem que ama, e que não irá mais amá-la, é o mundo encantado transmitido pelos pais" (CLÉMENT, 1996, p. 244-245).

herself to a watery grave, thereby fulfilling the nineteenth-century male's fondest fantasies of feminine dependency" (DJKSTRA, 1986, p. 42). 
Nesse sentido, a relação entre a morte e o canto feminino é tema recorrente na literatura e em diversas mitologias, portanto muito presente no imaginário ocidental. Em tal tema uma das figuras expoentes é a Sereia, ou também a Iara, a Mãe d'Água etc. A partir das vozes das Sereias a filósofa Adriana Cavarero discute a perspectiva da singularidade na filosofia e sua relação com questões da voz e do gênero.

\subsection{Sereias: vozes, singularidades e corpomídia}

- Amigos, não convém que somente um ou dois conheçam as predições que me fez a divina Circe: eu vo-las direi a fim de que, conhecendoas, afrontemos a morte ou escapemos ao destino fatal. A deusa me ordenou que evitasse, em primeiro lugar, a voz das feiticeiras Sereias e seu florido prado.

[...]

- Aproxima-te, ó famoso Ulisses, glória imensa dos gregos! Detém aqui o teu navio para escutares a nossa voz. Ninguém, até agora, passou com sua escura nau sem ter escutado o melifluo canto que sai de nossos lábios (HOMERO, 10 a.c. $^{28}$ ).
Nesse mar de concreto, reproduz Ilhas de Capri Prédios são rochedos, ela canta e exala charme Armas são o canto, a flauta, a lira Me ganha no encanto, na falta, pira

Tragam cera pros ouvidos de Homero Mas sua melodia é demais

E eu quero mais!

Mentes eternizam o que sentidos somatizam

Se os olhos idealizam, corações realizam

Entre os drinks, sexo, coisas

Noites babilonicas me usa, ousa!

Filha de Caliope, arma útil do desejo

Tá na pele, me fere

Ela é sutil como um beijo

(MC RAMONZIM, 2012 29 ).

A ideia da morte associada à mulher que canta está enraizada na cultura ocidental. Tanto no imaginário mitológico ambientado no cenário odisseico, quanto no meio urbano atual, em um rap produzido no ano 2014, a Sereia - metade mulher, metade animal encarna a fatalidade de sua voz harmoniosa, potente e irresistível. Mas onde reside o poder de sua voz?

(...) mesmo a tradição androcêntrica sabe que a voz provém da 'vibração de uma garganta de carne' e, exatamente porque o sabe, classifica-a na esfera corpórea - secundária, transitória e inessencial - reservada às mulheres. Feminilizados por princípio, tanto o aspecto vocálico da palavra quanto principalmente o canto comparecem como elementos antagonistas de uma esfera racional

\footnotetext{
${ }^{28}$ Trechos do Canto XII da Odisseia, editada pela Atena Editora, São Paulo, 1960.

${ }^{29}$ Trecho da música $O$ canto da sereia, do grupo Cartel MCs. Fontes: transcrição e https://www.vagalume.com.br/cartel-mcs/canto-da-sereia.html
} 
masculina centrada, por sua vez, no elemento semântico. Para dizer com uma fórmula: a mulher canta, o homem pensa (CAVARERO, 2011, p. 20).

Na Odisseia, Ulisses representa a ideia do herói da razão, eloquente, tentado pela transitoriedade do canto das Sereias, seres femininos, carnais, quase não-humanos. E se na Odisseia as Sereias aparecem como figuras capazes de proferir palavras, tal capacidade semântica se perde no imaginário ocidental no qual as sereias aparecem relegadas à condição de passividade e objetificação, a exemplo do verso Filha de Calíope, arma útil do desejo, do rap O canto da sereia, do grupo Cartel MCs, de autoria do MC Ramonzim.

Ao evidenciar a tradição que traz a representação da esfera do corpo pela mulher e a do espírito pelo homem, Adriana Cavarero coloca em questão a relação mente-corpo. A dissociação de tais conceitos nas culturas ocidentais é exemplificada no verso Mentes eternizam o que sentidos somatizam do mesmo rap.

Diante desse debate, ao pensar uma epistemologia do corpo que refuta a dicotomia mente-corpo, as autoras Christine Greiner e Helena Katz propõem uma teoria do corpomídia. Em tal perspectiva as autoras recusam a ideia do corpo como recipiente, na qual o corpo serviria de invólucro para as informações recebidas. As autoras argumentam que o corpo está em constante fluxo com o ambiente, desta maneira corpo e ambiente não são passivos nem estáticos, mas se modificam constantemente e sua relação torna o ambiente uma espécie de "contexto-sensitivo" (GREINER, KATZ, 2005, p. 129). Para as autoras:

\footnotetext{
O corpo não é um meio por onde a informação simplesmente passa, pois toda informação que chega entra em negociação com as que já estão. O corpo é resultado desses cruzamentos, e não um lugar onde as informações são apenas abrigadas. É com essa noção de mídia de si mesmo que o corpomídia lida, e não com a ideia de mídia pensada como veículo de transmissão. A mídia à qual o corpomídia se refere diz respeito ao processo evolutivo de selecionar informações que vão constituindo o corpo. A informação se transmite em processo de contaminação (GREINER, KATZ, 2005, p. 131).
}

Assim, pensar o corpo em fluxos permanentes de informação com o ambiente significa tirar o corpo da passividade à qual é reduzido na dicotomia mente-corpo e posicioná-lo em uma relacionalidade com o ambiente. 
Nesse processo a voz é fundamental, já que é manifestação sonora desse corpo que comunica em fluxo com o ambiente. Christine Greiner e Helena Katz propõem que haja uma "taxa de preservação que garante a unidade e sobrevivência dos organismos e de cada ser vivo em meio a transformação constante" (GREINER, KATZ, 2005, p. 130). Tal taxa de preservação se relaciona à singularidade abordada por Adriana Cavarero, que é atestada pela voz, já que:

\footnotetext{
A emissão fônica exaltada pelo canto, a voz que pressiona o ar e que faz vibrar a úvula, tem justamente uma função reveladora. Melhor ainda, mais que revelar, ela comunica. E comunica precisamente a unicidade verdadeira, vital e perceptível de quem a emite (CAVARERO, 2011, p. 20).
}

Dessa maneira, ao ser emitida a voz, não apenas revela a unicidade de quem a emite, mas também o valor relacional do vocálico. Nesse sentido, Adriana Cavarero afirma que "Destinada ao ouvido alheio, a voz implica uma escuta, ou melhor uma reciprocidade de fruição" (CAVARERO, 2011, p. 21-22).

A voz, então, é manifestação sonora do corpo. Sendo cada corpo único, a voz é a expressão mais profunda da singularidade do ser. Essa voz como manifestação do corpo que gera conhecimento e é único se opõe ao paradigma hegemônico do neutro, à ordem simbólica patriarcal que, segundo Cavarero, identifica o masculino com o racional e o feminino com o corpóreo, privilegiando o semântico em relação ao vocálico. É essa ordem simbólica patriarcal que perpetua afinal a dissociação entre mente e corpo, razão e emoção. E aí reside o poder e a fatalidade do canto das Sereias: seus corpomídias singulares recusam tal paradigma.

\subsection{Vocalidades e aspectos vocálicos em Ofélia presa nas cordas do piano}

A linguagem humana se liga, com efeito, à voz. O inverso não é verdadeiro (ZUMTHOR, 2007, p. 86). 
O linguista Paul Zumthor propõe uma distinção entre a oralidade e a vocalidade. Esta última é definida como "conjunto das atividades e valores da voz que lhe são próprios, independente da linguagem" (ZUMTHOR apud CAVARERO, 2011, p. 27). Ao recorte realizado por Zumthor de um campo autônomo de reflexão para a vocalidade, Adriana Cavarero acrescenta a fenomenologia vocálica da unicidade, que reporta à condição humana da unicidade manifestada através da voz. Nesta perspectiva a voz não é desprovida de sentido próprio e o sentido do que é dito transita da esfera acústica à palavra, ou seja, não se resume ao âmbito semântico. Portanto o ato da fala (ou do canto) é relacional, pois comunica - para além dos conteúdos específicos das palavras - a "relacionalidade acústica, empírica e material das vozes singulares" (CAVARERO, 2011, p. 29).

Em Ofélia presa nas cordas do piano são trabalhados recursos que valorizam aspectos vocálicos da voz, como pode ser conferido na partitura.

Partitura 1 - Ofélia presa nas cordas do piano, Jocy de Oliveira. 


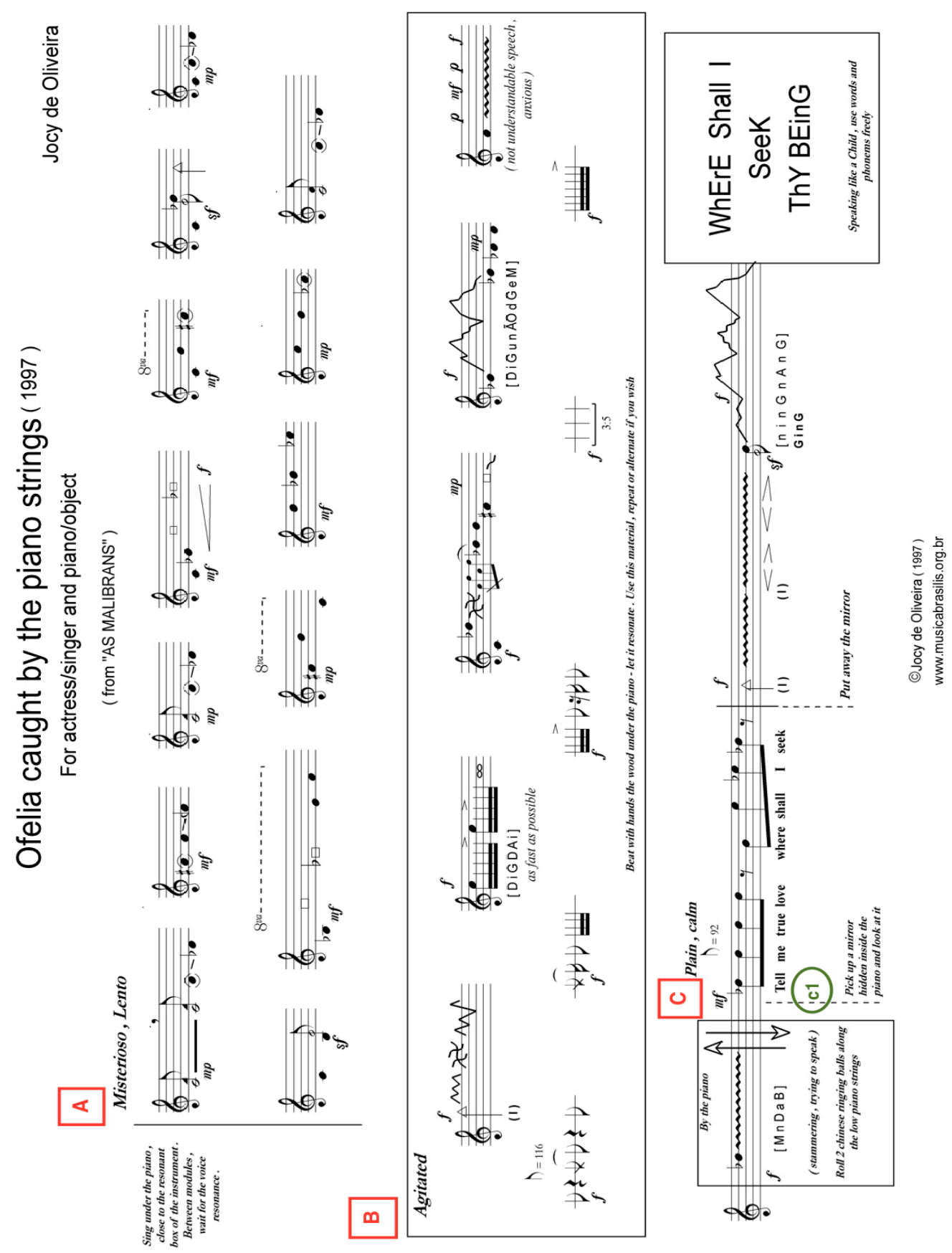




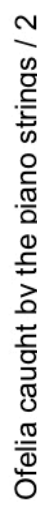
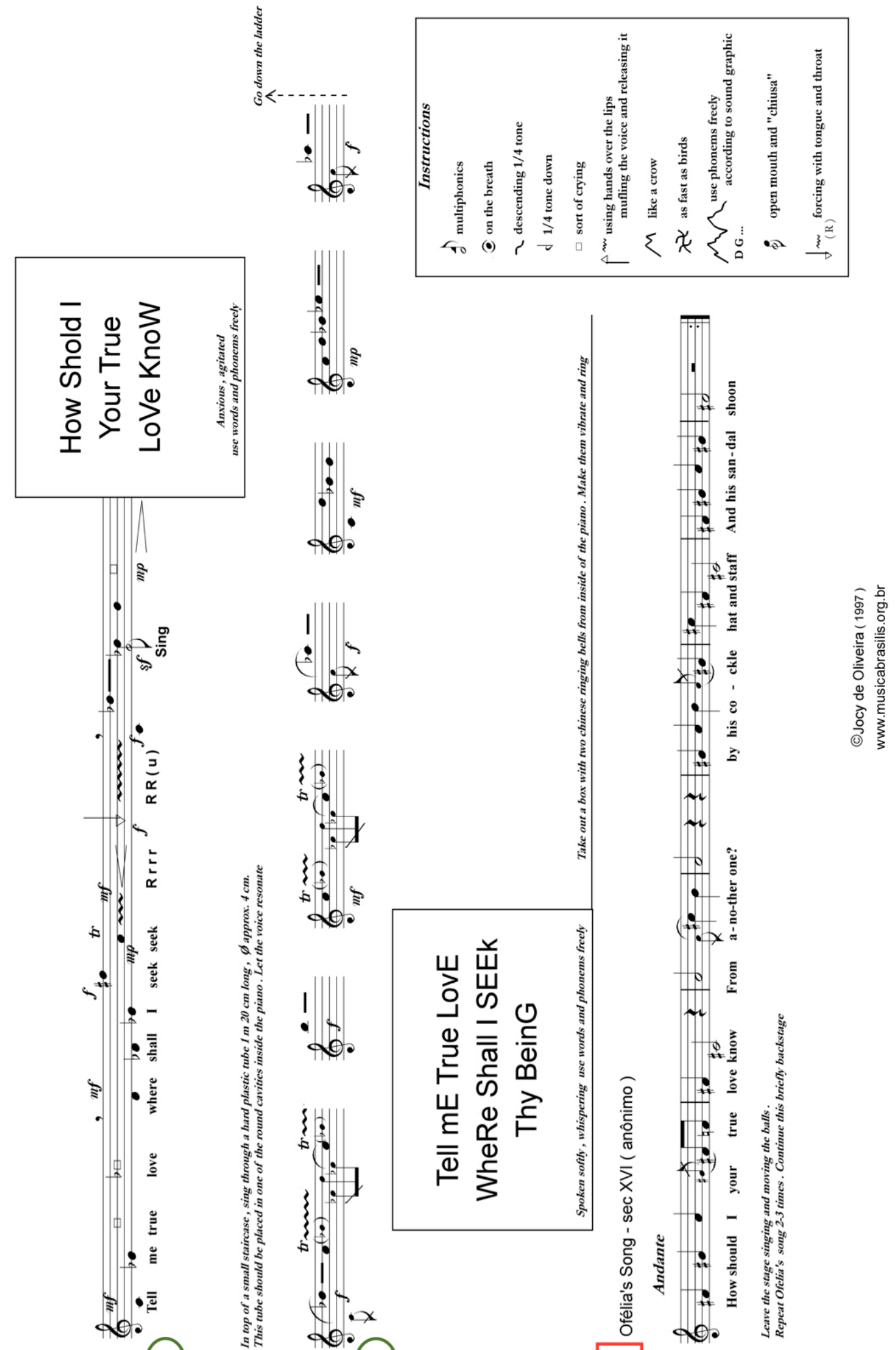

(ช)
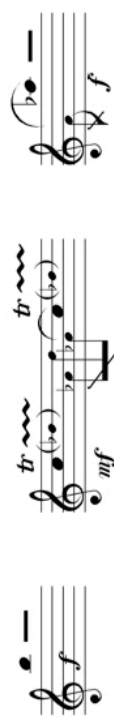

-

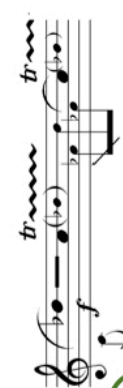

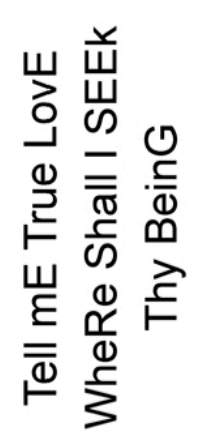
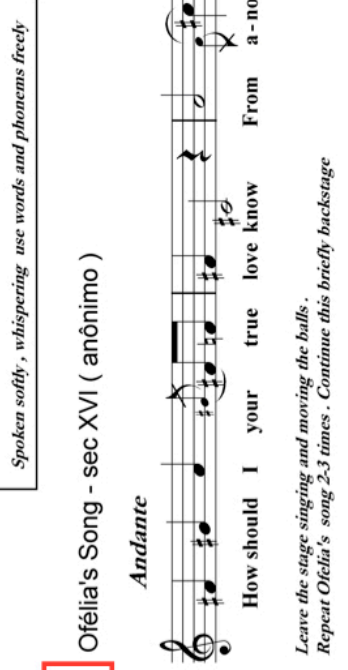

(8)

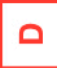


Fonte: Partitura editada e licenciada pelo Instituto Musica Brasilis, Rio de Janeiro, $2016^{30}$.

A partitura faz uso tanto de notação estrita quanto aberta. Se por um lado muitas vezes há um certo grau de indeterminação no que se refere à duração dos sons e às alturas - sendo deixados à escolha da atriz/cantora -, por outro lado é possível perceber um detalhamento rigoroso no que diz respeito aos timbres da voz, determinados por uma bula. São explorados vocalises, cantos harmônicos, sons anasalados, grunhidos, choro, trabalhos com fonemas, e um texto - ora cantado, ora falado - composto por trechos dos cantos de loucura de Ofélia em inglês, do original Hamlet e um trecho da canção renascentista Tell me true love, de John Dowland.

Mais uma vez, ao utilizar a personagem de Ofélia enquanto arquétipo, Jocy de Oliveira subverte o que seria esperado da personagem no imaginário ocidental. Enquanto o óbvio traria o canto de Ofélia para o lugar do belo - na perspectiva do "homem que fala e da mulher que canta" - a compositora trabalha com outras possibilidades estéticas, que enfatizam a corporeidade da personagem.

A peça também trabalha uma tessitura que subverte as classificações vocais tradicionais. Para cantar as duas oitavas exigidas na peça (do Si2 ao Si4) a cantora que interpretar Ofélia presa nas cordas do piano deve ter um trabalho vocal que extrapole os limites compreendidos nas classificações "contralto", "mezzo- soprano" ou "soprano"31. Não é à toa que na partitura está escrito que a música deve ser executada por uma "atriz/cantora", e não especifica o tipo de voz, como é feito tradicionalmente na música vocal de concerto, ou na ópera. Também neste aspecto a figura da diva - comumente associada à soprano - é subvertida.

Para elucidar a utilização dos recursos vocais - associada ao texto e forma da música - foi realizada a tabela abaixo, na qual o texto 1 refere-se ao trecho da canção

\footnotetext{
${ }^{30}$ As marcações sobre a forma realizadas para este trabalho.

${ }^{31}$ A classificação vocal tradicional determina as seguintes tessituras aproximadas para cada tipo de voz: contralto: Fa2 a Re4; mezzo-soprano: La2 a Fa4; soprano: Do3 a La4 (MOREIRA, p. 107, 1940). Além da extensão existem outros fatores que definem a classificação vocal, tais como a leveza ou peso da voz, agilidade etc.
} 
renascentista Tell me true love, de John Dowland, e o texto 2 aos trechos dos cantos de loucura de Ofélia em inglês, do original Hamlet, de Shakespeare.

Tabela $l$ - Estrutura de Ofélia presa nas cordas do piano, de acordo com recursos vocais e textos utilizados.

\begin{tabular}{|c|c|c|c|c|c|c|}
\hline \multirow[t]{2}{*}{ RECURSOS VOCAIS } & \multirow{2}{*}{$\begin{array}{l}\text { SEÇÃO A } \\
\text { Misterioso, } \\
\text { lento }\end{array}$} & \multirow{2}{*}{$\begin{array}{l}\text { SEÇÃO B } \\
\text { Agitado }\end{array}$} & \multicolumn{3}{|c|}{$\begin{array}{c}\text { SEÇÃO C } \\
\text { Pleno, calmo }\end{array}$} & \multirow{2}{*}{$\begin{array}{l}\text { SEÇÃO D } \\
\text { Andante }\end{array}$} \\
\hline & & & $\mathrm{c} 1$ & $\mathrm{c} 2$ & $\mathrm{c} 3$ & \\
\hline \multicolumn{7}{|l|}{ Multifônicos } \\
\hline \multicolumn{7}{|c|}{ Cantar na respiração } \\
\hline \multicolumn{7}{|c|}{ Como se estivesse chorando } \\
\hline \multicolumn{7}{|c|}{$\begin{array}{l}\text { Usar as mãos para cobrir os } \\
\text { lábios, abafando a voz e } \\
\text { soltando }\end{array}$} \\
\hline \multicolumn{7}{|c|}{ Como um corvo } \\
\hline \multicolumn{7}{|c|}{$\begin{array}{c}\text { Tão rápido quanto um } \\
\text { pássaro }\end{array}$} \\
\hline \multicolumn{7}{|c|}{$\begin{array}{l}\text { Usar livremente os fonemas } \\
\text { escritos, com as alturas de } \\
\text { acordo com o gráfico }\end{array}$} \\
\hline \multicolumn{7}{|c|}{ Boca chiusa com boca aberta } \\
\hline \multicolumn{7}{|c|}{$\begin{array}{c}\text { (R) forçado com língua e } \\
\text { garganta }\end{array}$} \\
\hline TEXTO & $\begin{array}{c}\text { Não } \\
\text { definido. }\end{array}$ & $\begin{array}{l}\text { Fonemas e fala } \\
\text { não } \\
\text { compreensível. }\end{array}$ & $\begin{array}{c}\text { Texto 1 } \\
\text { (trechos } \\
\text { cantados } \\
e \\
\text { falados) }\end{array}$ & $\begin{array}{c}\text { Textos 1 } \\
\text { e } 2 \\
\text { (trechos } \\
\text { cantados } \\
\mathrm{e} \\
\text { falados) }\end{array}$ & $\begin{array}{c}\text { Não } \\
\text { definido }+ \\
\text { Texto } 1 \\
\text { (completo, } \\
\text { falado) }\end{array}$ & $\begin{array}{l}\text { Texto } 2 \\
\text { (completo, } \\
\text { cantado) }\end{array}$ \\
\hline
\end{tabular}

Fonte: tabela elaborada para este trabalho.

Na tabela acima pode ser verificado que a peça é estruturada por seções indicadas por andamentos/humores. Também podemos perceber que há um interesse composicional no que diz respeito à relação entre os recursos vocais e as palavras. À medida em que o texto se torna mais completo e compreendido, diminuem as incidências de recursos vocais voltados para a vocalidade.

Nesse sentido é como se, ao contrário do que ocorre com as sereias no imaginário ocidental, Ofélia fosse ganhando capacidade semântica. Porém o texto que resulta de sua 
capacidade semântica é sem sentido, marcado pela loucura e o mais importante: o fim de sua vida será nas profundezas das águas. Portanto em Ofélia presa nas cordas do piano, esta canta sua existência se utilizando de cantos que evocam sua corporeidade, seu desejo de retorno às águas e à morte.

Dessa maneira os recursos vocais utilizados por Jocy de Oliveira na composição de Ofélia presa nas cordas do piano posicionam a personagem em uma nova centralidade, à medida em que enfatizam sua corporeidade e singularidade, informadas pela voz e aspectos performativos. Tal centralidade conferida à personagem não evita seu final trágico, mas emerge enquanto um grito de subversão aos modelos da figura feminina instituídos de acordo com os valores que reforçam a hegemonia masculina.

\subsection{Aspectos performativos: teatralidade, multimídia e metalinguagem}

A partitura de Ofélia presa nas cordas do piano traz um grande número de indicações performáticas. Para o efeito de excitação da ressonância do piano pela voz, por exemplo, há uma indicação escrita de que a cantatriz cante sob o piano, resultando tanto em um efeito auditivo quanto visual. A performance também aparece, portanto, como elemento integrante do plano composicional.

Se em 5 peças para Microvocalidades, de Flora Houlderbaum, a ressonância da voz por extensão através do piano participa da experimentação da artista na busca pelo traço de vocalidade, em Ofélia presa nas cordas do piano tal recurso - previsto no plano composicional - participa poeticamente da cena, causando um efeito sonoroperformático. Ofélia está presa nas cordas do piano, ou seja, ao posicionar-se embaixo do instrumento ele se torna seu cárcere e as cordas suas grades. Porém a voz da personagem ressoa através do que deveria prendê-la. A voz então aparece como meio de libertação, não apenas no plano dos recursos utilizados para tal canto - que refutam a estética do "belo", que tradicionalmente seria conferido à personagem de Ofélia -, mas através dos meios pelos quais se canta, que buscam ressonância e expansão onde deveriam estar aprisionados. 
Portanto, relações traçadas entre a personagem canônica de Ofélia no texto original de Shakespeare, na peça de Jocy de Oliveira e a trajetória de Maria Malibran trazem à tona discussões sobre as múltiplas facetas da diva e seu aprisionamento ao que é considerado "feminino" de acordo com valores que reforçam a hegemonia masculina e o patriarcado. Junto aos aspectos performativos, as escolhas estruturais e de recursos vocais feitas pela compositora abarcam estas questões de maneira lírica.

Afinal é a ópera - território lírico no qual cantaram e morreram tantas divas e personagens femininas - a linguagem escolhida por Jocy de Oliveira para este trabalho. A artista extrapola a linguagem ao utilizar recursos multimídia e metalinguagem. Os limites tênues entre atrizes e personagens conduzem a relação da peça com a realidade e o público, de maneira entrelaçada. A metalinguagem se dá em vários níveis, considerando que o universo da ópera permeia tanto as vidas das artistas participantes, quanto de Ofélia e Maria Malibran.

Figura 7 - Quadro sobre a relação atrizes- personagens em Ofélia presa nas cordas do piano (OLIVEIRA, 2000).

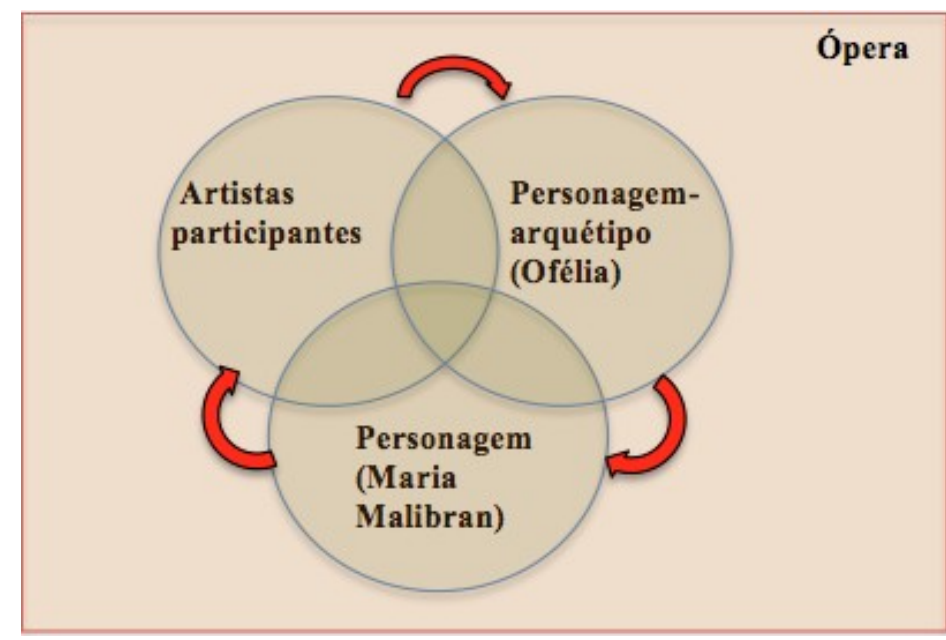

Fonte: quadro elaborado para este trabalho.

No quadro está proposto que os três âmbitos compartilham intersecções entre si e as setas sugerem um movimento no qual as cantoras/atrizes interpretam Ofélia, que por sua vez serve de arquétipo para a vida de Maria Malibran, que tem a realidade como 
ponto em comum com as cantoras/atrizes ${ }^{32}$. Neste aspecto o próprio ato de cantar ópera as conectam a Maria Malibran.

A entrada da segunda atriz em palco não estava prevista na partitura. Trata-se de um recurso performático, que se encaixa no contexto da ópera. A peça foi escrita e performada isoladamente, anos antes da ópera ser estreada. O desdobramento das personagens em duas atrizes ocorre a partir do momento em que, na ópera, Ofélia serve de arquétipo para o universo das divas. Certamente tal desdobramento está ligado à cena em que Ofélia se olha no espelho. A entrada da "segunda Ofélia" transporta seu duplo para fora do espelho e traz para o plano da cena, no qual a todo momento a relação com a realidade está em jogo.

Dessa maneira, em Ofélia presa nas cordas do piano, o plano composicional (escrito) trabalha elementos sonoro-performativos, na medida em que os aspectos estruturais, recursos vocais e performáticos participam do âmbito poético da peça inscrita na ópera, criando com o público um ambiente no qual estão entrelaçados aspectos do real e teatral.

Ao passo que a metalinguagem participa em um entrelaçamento entre a ópera e a realidade $^{33}$, enquanto recurso teatral ela destaca o caráter fictício, pois está na esfera da teatralidade, que de acordo com Josette Féral pode ser definida como "a criação de um universo ficcional, de um espaço separado da vida quotidiana, de um espaço de transição entre o real e a ficção" (FÉRAL, 2009, p. 83).

No caso da ópera, um dos importantes aspectos da teatralidade é a própria música, que - assim como a iluminação, o teatro enquanto espaço, figurino etc - se configura enquanto moldura que separa o universo ficcional da realidade cotidiana. A moldura da teatralidade torna possível a sedução - principalmente por intermédio da

\footnotetext{
${ }^{32}$ Aqui nos referimos a três âmbitos e não quatro por considerar que uma atriz representa o desdobramento da outra, ou seja, elas têm função similar no que diz respeito às relações entre atrizes e personagens e enfatizam - sendo uma só e suas repetições e desdobramento - o entrelaçamento entre real e fictício.

${ }^{33}$ Cabe dizer que os recursos multimídia tornam a rede ainda mais complexa ao envolver outras personagens e vozes no restante da ópera. Em As Malibrans, além de Ofélia e Maria Malibran, são trabalhadas as personagens Desdêmona e Iphigênia.
} 
música - que mascara a violência com que são tratadas as mulheres no universo da ópera. De acordo com Catherine Clément:

\begin{abstract}
A música faz esquecer a intriga, mas a intriga arma uma cilada para o imaginário. Age em surdina, à vista de todos, mas fora dos códigos dos prazeres da ópera. (...) Contudo, para além da ideologia romântica, os laços da trama servem para prender as personagens e conduzi-las à morte por transgressão (CLÉMENT, 1999, p. 18).
\end{abstract}

Nesse sentido, para a autora a música serve como um aspecto mascarador do caráter punitivo dos livretos de ópera. Para além dos prazeres de se assistir a tal espetáculo, há muitos valores que estão sendo reproduzidos e agregados ao imaginário de seu público. Assim ocorre uma naturalização da violência contra a mulher, emoldurada pela música encenada.

\title{
2.5. Considerações finais do capítulo
}

E a ópera (...) não terá sido mais que o grande sono de sua violentação [das mulheres], a vitória representada e mal garantida que os homens se atribuíam em uma luta animada só por eles, só por eles desejada. Elas continuarão a cantar, belas e vivas com uma voz que não há de sofrer mais ameaça alguma. Dirão coisas completamente diferentes das palavras sopradas pelo delírio e pela dor. Elas não vão mais pedir que as deixem morrer (CLÉMENT, 1996, p. 246).

Catherine Clément sugere, na conclusão de seu livro, que em um momento "pósópera" ainda por vir, as mulheres não mais terão seu canto sujeitado ao discurso patriarcal. Nesse sentido, ao invés de negá-la - como sugerido por Catherine Clément -, Jocy de Oliveira apropria-se da linguagem da ópera para assim subverter seu discurso tradicional. Para tanto, a artista traz para um primeiro plano aspectos vocálicos-performáticos que retrabalham tanto o arquétipo de Ofélia quanto a perspectiva da obscuridade do universo das divas.

Portanto, em Ofélia presa nas cordas do piano são trabalhados recursos vocais que exploram uma gama de possibilidades que extrapolam o "belo" e - junto aos aspectos performáticos - trazem o corpo para o âmbito ativo. Assim, a maneira como a voz é trabalhada por Jocy de Oliveira recusa o paradigma cartesiano e participa em uma 
ampliação de linguagem da ópera, em um caminho que põe em foco os corpos participantes. Assim, a música - ao contrário de mascarar - passa a enfatizar os valores que dizem respeito ao papel das mulheres no universo da ópera.

Dessa maneira, Jocy de Oliveira cria, por meio da música, uma "contramitologia" - como proposta por María Xosé Queizán - ou, transpondo para os termos de nosso assunto, uma "contraópera", na qual a linguagem está a todo tempo sendo questionada e reinventada. Em tal reinvenção é fundamental a utilização da metalinguagem, uma vez que em As Malibrans é questionado o papel das mulheres no universo da ópera e as artistas representam (no palco de ópera) mulheres que por sua vez representaram as personagens condenadas à loucura e morte pelo caráter punitivo dos libretos tradicionais. Portanto, em As Malibrans as mulheres representam ciclicamente a própria morte.

Desse modo, em As Malibrans o ciclo da morte de mulheres na ópera não é quebrado, porém é posto em evidência por meio do grito de corporeidade emanado da voz e assim não "age em surdina", ou atinge o imaginário de seu público de maneira a naturalizar tal violência. Ao contrário, os aspectos vocálico-performáticos, junto à forma e utilização da metalinguagem, agem como um grito que tanto evidencia a violência relegada às mulheres na ópera, quanto provoca uma reinvenção da linguagem. 


\title{
CAPÍTULO 3 - A REIVINDICAÇÃO DO CORPO: ARCO, DE IARA RENNÓ
}

\subsection{Controle do corpo}

\begin{abstract}
A paixão sexual destruía não somente a autoridade dos homens sobre as mulheres (...), mas também a capacidade do homem de governar a si mesmo, fazendo-o perder esta preciosa cabeça onde a filosofia cartesiana situaria a fonte da razão. Por isso, uma mulher sexualmente ativa constituía um perigo público, uma ameaça à ordem social, já que subvertia o sentido de responsabilidade dos homens e sua capacidade de trabalho e autocontrole (FEDERICI, 2017, p. 343).
\end{abstract}

Em seu livro Calibã e a bruxa: mulheres, corpo e acumulação primitiva, a autora Silvia Federici discute a relação entre a emergência do sistema capitalista e a caça às bruxas realizada na Europa e colônias. A caça às bruxas se configura, portanto, como uma das principais maneiras do Estado e da Igreja transformarem as potencialidades dos indivíduos em força de trabalho, ao utilizarem-se do controle do corpo como pilar de dominação.

Valendo-se da caça às bruxas - que acarretou no assassinato de centenas de mulheres - Estado e Igreja puderam operar a "transformação da atividade sexual feminina em um trabalho a serviço dos homens e da procriação" (FEDERICI, 2017, p. 346), estabelecendo a função da mulher no modelo da família capitalista, fundamental em sua manutenção.

Nesse sentido, o que a autora se refere no trecho acima como paixão sexual, diz respeito à sexualidade não procriativa, que passa a ser condenada e reforça o pensamento cartesiano que designa a mente/espírito ao homem e a carne/corpo à mulher ${ }^{34}$. Portanto, a linguagem da caça às bruxas determina o arcabouço cultural do que é considerado feminino e do que é masculino e dessa maneira os discursos que reforçam o logofalocentrismo encontram no controle do corpo seu principal pilar de dominação.

\footnotetext{
${ }^{34}$ Silvia Federici comenta: “... podemos dizer que a linguagem da caça às bruxas "produziu” a mulher como uma espécie diferente, um ser sui generis, mais carnal e pervertido por natureza. Também podemos dizer que a produção da "mulher pervertida" foi o primeiro passo para a transformação da vis erotica feminina em vis lavorativa - isto é, um primeiro passo na transformação da sexualidade feminina em trabalho" (FEDERICI, 2017, p. 344).
} 
Dois séculos após o fím da caça às bruxas institucionalizado não apenas ainda estão presentes os efeitos de tal controle do corpo feminino, como encontramos exemplos de mulheres que são assassinadas por acusação de bruxaria ${ }^{35}$. Nesse sentido, a reinvindicação pelo corpo é necessária para uma recodificação dos espaços simbólicos essencial para subverter as estruturas - e é nesse âmbito que se inscreve o trabalho artístico de Iara Rennó.

\subsection{Iara Rennó: corpos subversivos}

A artista trabalha a temática do corpo e da sexualidade utilizando-se da articulação entre as linguagens da literatura e música. Nascida em São Paulo - na família de longa tradição musical Espíndola - Iara Rennó é uma artista polivalente. Cantora, guitarrista, produtora, atriz, performer e poeta, a artista lançou em 2016 o disco $\operatorname{Arco}^{36}$. Com algumas das canções criadas a partir de poemas de seu livro de poesia erótica língua brasa carne flor, o álbum Arco foi lançado conjuntamente com o álbum Flecha. Enquanto Flecha lida com uma ideia de masculino (reunindo inclusive apenas músicos homens), Arco é regido por uma ideia de feminino. Além de Iara Rennó (voz, guitarra, baixo, composições, produção e direção artística), o disco Arco reuniu as artistas Mariá Portugal (bateria, programação e vocais) e Maria Beraldo Bastos (clarone, cavaquinho e vocais) para tocar o conjunto de canções ligadas ao gênero rock. Tanto o livro quanto o disco tratam de temáticas relacionadas à sexualidade feminina, em uma abordagem lírica na qual o corpo é tratado em primeiro plano. De acordo com a artista,

Como me identifico com o gênero feminino, este é o eu lírico do discurso. Como ainda nos dias de hoje uma mulher falar abertamente sobre sexo e o que lhe dá prazer é subversivo porque contraria a lógica da sociedade de consumo

\footnotetext{
${ }^{35}$ Em 2014 Fabiane Maria de Jesus foi assassinada no Guarujá- SP, por ter sido acusada por seus vizinhos - através de falsas informações - de sequestrar crianças para realizar rituais de magia negra. Cerca de cem pessoas participaram do linchamento que acarretou em sua morte e cerca de mil pessoas estavam presentes na cena.

${ }^{36}$ Disponível no link www.youtube.com/watch? $\mathrm{v}=\mathrm{aNEPIMog} 6 \mathrm{yM} \& \mathrm{t}=24 \mathrm{~s}$
} 
machista e misógina, isso chamou a atenção de público e mídia (RENNÓ, $\left.2016^{37}\right)$.

Nessa perspectiva, ao tratar da sexualidade feminina, Iara Rennó subverte discursos que reforçam o logofalocentrismo e a família em seus termos capitalistas. Em Arco - além dos seus poemas de caráter erótico - a subversão ocorre também no âmbito da sonoridade vocal e instrumental, que é trabalhada de maneira a conferir extrema corporeidade ao disco.

Dessa maneira, em Arco a temática e a sonoridade se unem pela sexualidade. Além de propor uma formação instrumental pouco convencional, Iara Rennó, ao cantar, explora uma ampla gama de sonoridades que convidam a uma escuta também ampla, que se volta à corporeidade do som e se concretiza na temática do sexo. São utilizados recursos como gritos, vibratos exagerados, gemidos, timbres anasalados, trocas rápidas de regiões da voz, percussão vocal, textos falados, entre outros. Em uma entrevista feita por Leonardo Lichote, Iara Rennó ressalta sobre o disco Arco:

A temática sexual vinha do livro, estava debaixo da pele, ela está concentrada no disco que tem o discurso mais subjetivo, mais letras minhas, voltado pra dentro, pro sujeito. E o sexo combinava com essa sonoridade mais chocante, com essa formação que tira mais do lugar comum, te leva mais pros seus desejos, pro seu subconsciente (RENNÓ, 2016, p. $12^{38}$ ).

Tal "sonoridade chocante" está muito ligada à formação instrumental do disco, às escolhas harmônicas e rítmicas e à maneira como são distribuídos os instrumentos, formando texturas pouco convencionais, que convidam a uma escuta voltada para as sensações. Por exemplo, na música Meus vãos (faixa 07) o seguinte poema é cantado três vezes.

\author{
veneno \\ veneno \\ veneno \\ eu quero todo o teu
}

\footnotetext{
${ }^{37}$ Entrevista de Iara Rennó concedida a Alisson Prando e Vinicius Valente, da Disco Punisher, disponível no link https://discopunisher.wordpress.com/category/iara-renno/

${ }^{38}$ LICHOTE, 2016, p. 12.
} 


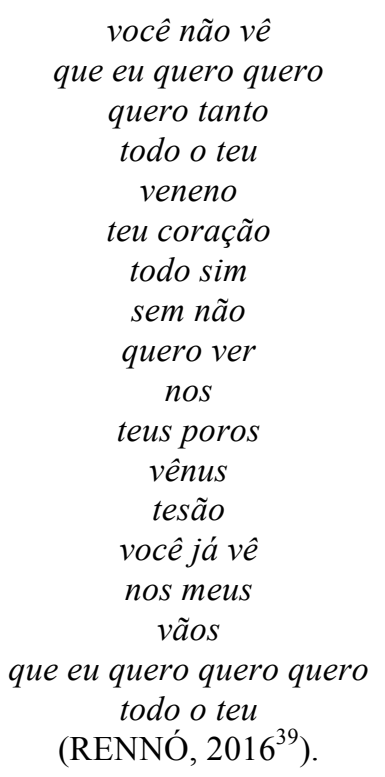

$\mathrm{Na}$ primeira vez ele é cantado em uníssono com guitarra, clarone e bateria. A bateria marca cada nota com um som percussivo e executa rulo nas notas longas. O texto - em uníssono com os instrumentos - é iniciado direto, sem introdução e a rítmica da música está em função do texto, formando compassos quebrados. A parte cantada da música trabalha exclusivamente com o pentacorde [G A Bb C Db], sendo que na melodia aparecem apenas as notas $\mathrm{A} \mathrm{Bb} \mathrm{C} \mathrm{Db}$. É utilizado um efeito na voz, que gera um reverb distorcido.

Há uma pequena ponte instrumental para a segunda repetição do texto, na qual há a inserção de um sintetizador e os instrumentos passam a marcar a rítmica em $2 / 4$. Um trecho da ponte e o início da segunda repetição do texto estão transcritos abaixo:

Partitura 2 - Transcrição do trecho 0:37 - 0:49 da música Meus vãos (RENNÓ, 2016).

\footnotetext{
${ }^{39}$ Encarte do disco Arco.
} 

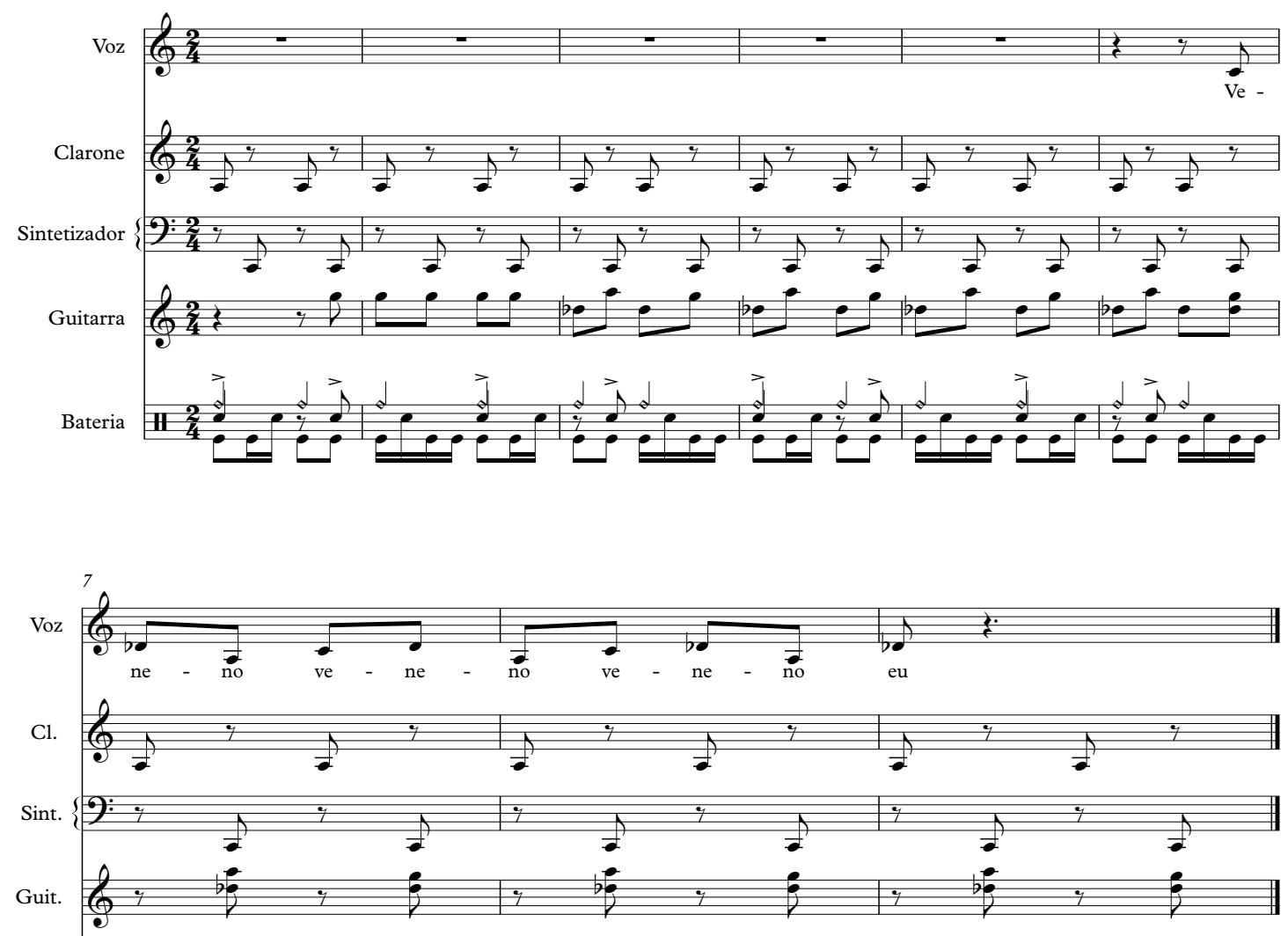

Fonte: transcrição elaborada para este trabalho.

Pode ser percebido que, apesar dos instrumentos estarem em 2/4, há um deslocamento no que diz respeito às acentuações e ciclos rítmicos, seguindo a ideia da voz que desloca o tempo pelas sílabas tônicas das palavras. O clarone e sintetizador - que são apresentados com timbres similares - fazem um jogo marcando tempo e contratempo. A guitarra marca o contratempo, inicialmente tocando suas notas agudas e depois os acordes no contratempo. A bateria faz um ciclo de três compassos, que é determinado pela batida na caixa acentuada:

Partitura 3 - Ciclo da caixa da bateria do trecho 0:37 - 0:49 da música Meus vãos (RENNÓ, 2016).

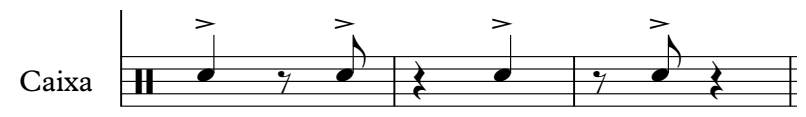

Fonte: transcrição elaborada para este trabalho. 
No início do texto, a voz repete por três vezes a palavra veneno, sempre em colcheias. Como a palavra tem três sílabas, a cada repetição da palavra a sílaba tônica é deslocada no compasso.

Após a segunda repetição do texto há uma parte instrumental em que o clarone faz um ostinato em semicolcheias como base para um solo de guitarra com distorção e poucas notas. A bateria nesse momento faz uma batida clássica de rock. Enquanto no solo de guitarra as notas tocadas se mantêm as mesmas da parte vocal, no ostinato do clarone há uma ampliação das notas, trabalhando com quase todo total cromático, exceto pelas notas D Gb G.

Partitura 4 - Transcrição do ostinato do clarone (sons reais) do trecho 01:24 - 01:58 da música Meus vãos (RENNÓ, 2016).

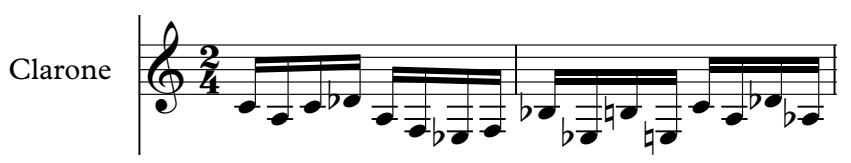

Fonte: transcrição elaborada para este trabalho.

O ostinato sofre variações em suas repetições, com algumas notas longas ou pausas para respiração da instrumentista e considerando que - apesar da repetição ser um recurso recorrente nesta música e no disco como um todo - cada repetição de cada elemento é diferente toda vez que ocorre. Assim, o texto é cantado três vezes, mas o arranjo muda a cada repetição, assim como a cada repetição do ostinato, ele é tocado de uma maneira diferente. Dessa maneira, ao passo que há uma certa estaticidade produzida pela repetição, a música está sempre em movimento.

$\mathrm{Na}$ terceira repetição do texto, o clarone e o sintetizador continuam no jogo de colcheias, enquanto a guitarra acompanha a voz em uníssono. A música termina na repetição da palavra "quero", com os instrumentos ralentando, enquanto Iara Rennó grita a palavra a repetindo rapidamente várias vezes, em um registro agudo.

Os recursos de uníssono, deslocamentos rítmicos feitos por acentuações e ostinatos são amplamente utilizados no disco. Tais recursos, combinados a uma certa estaticidade 
harmônica, faz chamar atenção de quem ouve para a textura, conferindo ao disco esta "sonoridade chocante", ligada às sensações. A maneira como a voz é trabalhada, buscando diferentes timbres e recursos como gritos e gemidos, é somada à sonoridade instrumental e juntas conferem materialidade ao trabalho.

\subsection{Corpo-voz: êxtase material}

O deslocamento de paradigma da esfera do pensar para a esfera do agir confere ao sujeito-corpo materialidade. Nesse âmbito não há mais a ideia de uma mente etérea, separada do corpo terreno, e o sujeito se dá na ação. Dessa maneira o corpo - permeado de sentidos sociais - é o recorte mais efetivo da ação como materialidade. Nesse sentido, tanto o gênero quanto a música, constituem materialidade.

Esse assunto é abordado por Talitha Couto Moreira em seu texto Música, materialidade e relações de gênero: categorias transbordantes. A autora aponta que, ao focar na potência de ação da música e das relações de gênero, é possível pensar um ser “permeável, aberto a interações, em consonância com instâncias também entendidas como fluidas e permeáveis, que são a música e as relações de gênero" (MOREIRA, 2013, p. 72).

Em uma abordagem etnomusicológica, a autora discute - para tratar da materialidade enquanto ponto em comum entre música e relações de gênero - aspectos do texto Os pronomes cosmológicos e o perspectivismo ameríndio, do antropólogo Eduardo Viveiros de Castro. O mesmo texto é utilizado na música Corpo Selvagem (RENNÓ, faixa 04, 2016).

O poema da música é formado pelos seguintes trechos do texto do antropólogo:

\footnotetext{
Entre a subjetividade formal das almas e a materialidade substancial dos organismos, o corpo.

O corpo como feixe de afecções e capacidades.

O corpo ser uma roupa, ou uma roupa ser um corpo.

Ocultar uma essência humana sob uma aparência animal.

Vestir uma roupa-máscara, ativar os poderes de um corpo outro (RENNÓ, fiaxa 04, 2016; CASTRO, 1996, p. 128, 133).
}

A estes trechos Iara Rennó acrescenta no refrão o verso "O chocalho do xamã é um acelerador de partículas”. 
A dupla de discos "Arco e Flecha" é proposta a partir de uma esfera ritualística, voltada para o universo indígena, como sugere o título. $\mathrm{O}$ universo indígena permeia o trabalho de Iara Rennó, tanto no que diz respeito à temática, quanto a figurinos, pinturas corporais, performance e concepção artística como um todo ${ }^{40}$. Assim, a partir da música Corpo Selvagem, Iara Rennó assume em seu disco uma concepção específica de corpo, que está voltada para a maneira material e terrena com que comumente o corpo é concebido em culturas indígenas.

Figura 8 - Iara Rennó performando Macunaíma Ópera Tupi

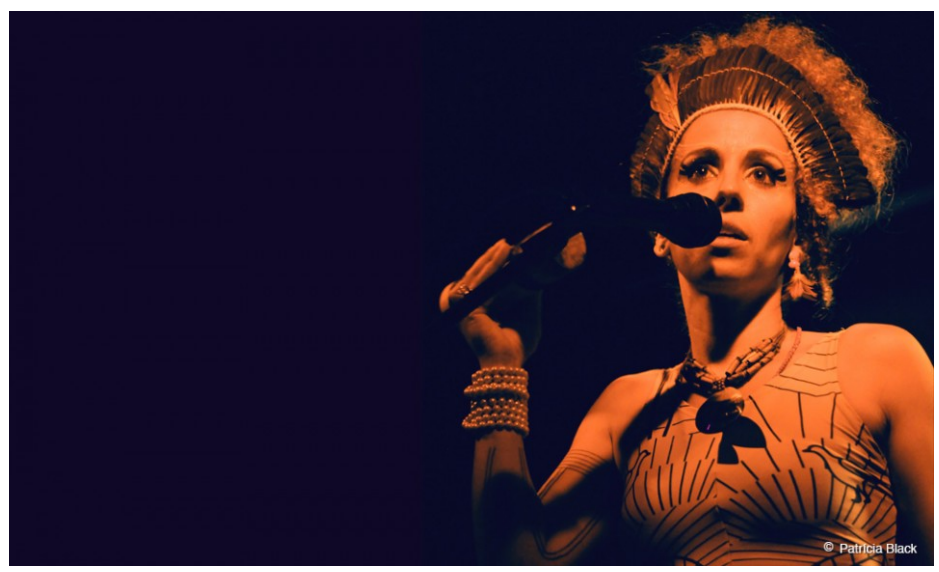

Fonte: http://www.locomotivacultural.com.br

Ao analisar estudos sobre rituais dos povos indígenas Wauja (Alto Xingu) e Xambá (Olinda, PE) Talitha Couto Moreira mostra como rituais musicais - que envolvem a performance como um todo - atuam em mão dupla com identidades de gênero. Nestes rituais ocorrem "inversões de gênero" por meio de transe, do qual a música é veículo. Nesse sentido, "gênero e música interpenetram-se, ao ponto de atuarem um sobre o outro" (MOREIRA, 2013, p. 76).

\footnotetext{
${ }^{40}$ Em 2008 Iara Rennó lançou o álbum Macunaíma Ópera Tupi, que reuniu artistas de diversas práticas para cantar e tocar músicas da artista baseadas em Macunaíma, de Mário de Andrade. Em janeiro de 2019 o trabalho foi revisitado e apresentado como uma Transcriação, resultando em um trabalho multimídia criado e dirigido por Iara Rennó.
} 
A partir do perspectivismo ameríndio formulado por Viveiros de Castro - no qual a ideia de "roupa" está ligada a uma forma de acesso a um determinado ponto de vista Talitha Couto Moreira afirma:

(...) certas práticas ou estilos musicais são utilizados como uma manta, ou uma peça de roupa que ajuda a definir o gênero dos seres em questão, ou construir suas sexualidades. Vê-se nessas observações, que a música ocupa um lugar de equivalência entre elementos pertencentes à esfera material, "como uma manta" na construção de gênero e sexualidade dos seres envolvidos (MOREIRA, 2013, p. 77).

Nesse sentido, uma vez que a música é entendida enquanto potência de ação - em uma perspectiva mais mundana do que ideal - ela "torna-se capaz de criar, modificar, desestabilizar a condição dos seres que com ela interage" (MOREIRA, 2013, p. 78). Nessa concepção em que gênero e música se interferem mutuamente, as relações de gênero apontam para uma fluidez de estados, no qual o dualismo "feminino-masculino" está presente, porém está em fluxo.

Tal concepção encontra consonância com a ideia de "feminino-masculino" presente em Arco e Flecha. De acordo com Iara Rennó:

O "Arco" é o feminino, mas é mais violento. O "Flecha", masculino, é mais dócil. (...) O "Flecha" é mais fálico, o "Arco" tem mais o meu discurso, é o que absorve. Esse buraco que puxa pro obscuro, que tem muito a ver com essa discussão atual. É como diz aquela música do Negro Leo: "Quem tem medo de buceta?". Talvez os discos sejam masculino e feminino, mas são transgêneros (RENNÓ, 2016, p. $12^{41}$ ).

\footnotetext{
${ }^{41}$ Entrevista de Iara Rennó concedida a Leonardo Lichote, do Globo.
} 
Figura 9 - Capas dos discos Arco e Flecha (RENNÓ, 2016).

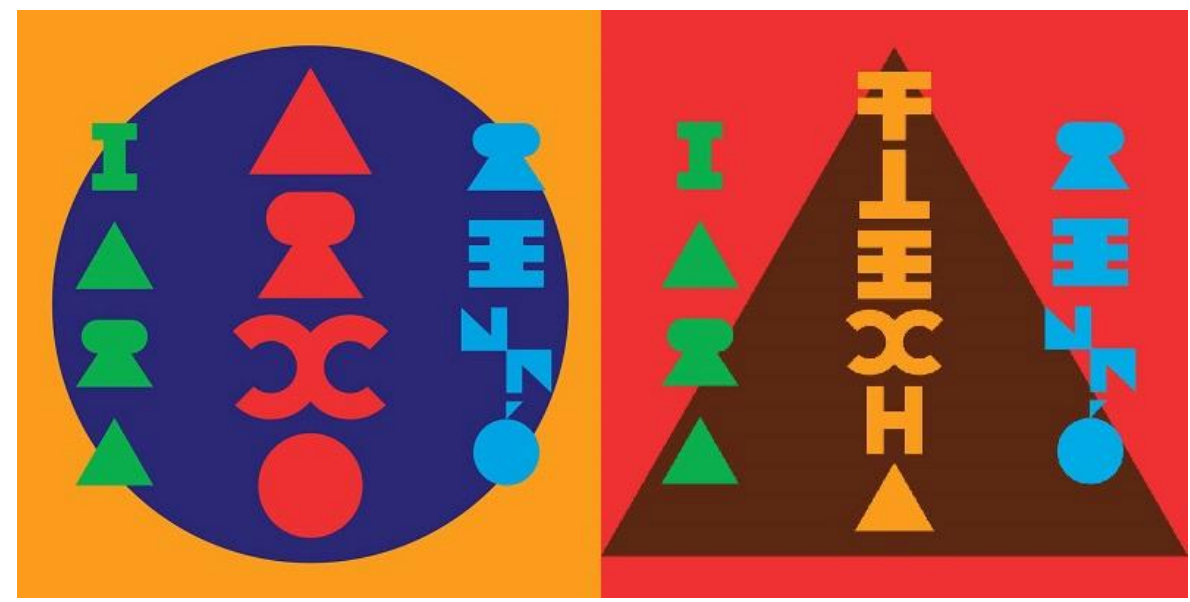

Fonte: http://trabalhosujo.com.br/os-75-melhores-discos-de-2016-48-iara-renno-arco-e-flecha/

Assim, em Arco corpo e música estão conectados pela materialidade conferida pelas palavras e sonoridades trabalhadas. A maneira fluida com que as relações de gênero perpassam o disco também participam de sua concepção material, uma vez que "O corpo [pode] ser uma roupa, ou uma roupa ser um corpo" (CASTRO, 1996, p. 128). Dessa forma, Iara Rennó expressa seu gênero e sexualidade - marca de sua singularidade -servindo-se da música, que - pensada enquanto materialidade - age como "manta" que veste a artista com tais características de sua singularidade.

Nesse aspecto o trabalho vocal realizado pela artista em Arco atesta a materialidade do corpo em um nível profundo. A voz veicula as palavras, participa da sonoridade e se inscreve enquanto marca de gênero.

De acordo com o linguista Paul Zumthor, a voz possui plena materialidade, uma vez que apresenta qualidades que dizem respeito tanto à cultura, gênero etc, quanto a características tais quais tom, timbre, alcance, altura e registro (ZUMTHOR, 2005, p. 62). A voz possui, portanto, uma qualidade de emanação do corpo e que o representa sonoramente de forma plena (ZUMTHOR, 2007, p. 27). O autor afirma: 
Mas que as palavras resistem, elas têm uma espessura, sua existência densa exige, para que elas sejam compreendidas, uma intervenção corporal, sob uma forma de uma operação vocal (ZUMTHOR, 2007, p. 77).

Nesse sentido, Iara Rennó articula as palavras valendo-se da sonoridade, que são ressignificadas a partir da maneira com que a artista as canta e as envolve instrumentalmente.

Para conferir a maneira com que a voz foi trabalhada no disco Arco foi realizada a tabela abaixo. Os quadros foram preenchidos por meio da observação de cada aspecto elencado, realizadas a partir da escuta do disco. Foram anotados apenas elementos que surgem como novidade e considerados relevantes em cada música.

Tabela 2 - Mapeamento de características vocais em Arco (RENNÓ, 2016).

\begin{tabular}{|c|c|c|c|c|c|}
\hline $\begin{array}{l}\text { TEMPO/ } \\
\text { PARTE } \\
\text { DA } \\
\text { MÚSICA }\end{array}$ & TIMBRE & $\begin{array}{c}\text { EFEITOS } \\
\text { ELETRÔNCOS }\end{array}$ & $\begin{array}{l}\text { RECURSOS } \\
\text { VOCAIS }\end{array}$ & TIPO DE TEXTO & $\begin{array}{c}\text { QUANTIDADE } \\
\text { DE VOZES/ } \\
\text { QUEM } \\
\text { CANTA }\end{array}$ \\
\hline $00: 16$ (A) & $\begin{array}{l}\text { Anasalado, } \\
\text { agudo, } \\
\text { metálico, } \\
\text { alto e } \\
\text { frontal. }\end{array}$ & $\begin{array}{l}\text { Duplicação, } \\
\text { delay, phaser. }\end{array}$ & & Texto da canção. & $\begin{array}{l}\text { Uma (Iara } \\
\text { Rennó). }\end{array}$ \\
\hline 00:59 (B) & & & & Texto da canção. & $\begin{array}{l}\text { Coro a } 3 \text { vozes } \\
\text { (Iara Rennó e } \\
\text { outras } \\
\text { mulheres). }\end{array}$ \\
\hline 01:32 (A) & $\begin{array}{l}\text { Menos } \\
\text { frontal, } \\
\text { mais } \\
\text { próximo do } \\
\text { registro de } \\
\text { cabeça. }\end{array}$ & $\begin{array}{l}\text { Delay na } \\
\text { colcheia. }\end{array}$ & & Vocalise (“Uh"). & $\begin{array}{l}\text { Uma (Iara } \\
\text { Rennó). }\end{array}$ \\
\hline 01:48 (A) & & $\begin{array}{l}\text { Duplicação, } \\
\text { delay, phaser } \\
\text { (como no início). }\end{array}$ & Glissando. & Vocalise ("Uh"). & $\begin{array}{l}\text { Uma duplicada } \\
\text { (Iara Rennó). }\end{array}$ \\
\hline
\end{tabular}




\begin{tabular}{|l|l|l|l|l|l|}
\hline 02:11 (A) & & & $\begin{array}{l}\text { Gritinho, como } \\
\text { se estivesse em } \\
\text { uma festa. }\end{array}$ & “Uh". & $\begin{array}{l}\text { Uma (Iara } \\
\text { Rennó). }\end{array}$ \\
\hline $\mathbf{0 3 : 4 9}$ (C) & & & & & $\begin{array}{l}\text { Alternância } \\
\text { entre uma voz } \\
\text { fixa e a mesma } \\
\text { voz com coro } \\
\text { (Iara Rennó e } \\
\text { outras } \\
\text { mulheres). }\end{array}$ \\
\hline \hline
\end{tabular}

2- INSTANTE (Iara Rennó, Júlia Rocha, Mariá Portugal)

\begin{tabular}{|c|c|c|c|c|c|}
\hline 00:25 (A) & $\begin{array}{l}\text { Canta um } \\
\text { pouco } \\
\text { como se } \\
\text { estivesse } \\
\text { gemendo. }\end{array}$ & $\begin{array}{l}\text { Efeito band pass } \\
\text { às vezes, } \\
\text { causando } \\
\text { alternância entre } \\
\text { a voz com este } \\
\text { efeito e sem. }\end{array}$ & & Texto da canção. & $\begin{array}{l}\text { Uma (Iara } \\
\text { Rennó). }\end{array}$ \\
\hline 00:52 (A) & & & $\begin{array}{l}\text { Gemidos, } \\
\text { grunhidos e } \\
\text { prolongamentos } \\
\text { das palavras } \\
\text { quebrando a } \\
\text { voz, através de } \\
\text { golpes de glote. }\end{array}$ & Texto da canção. & $\begin{array}{l}\text { Uma (Iara } \\
\text { Rennó). }\end{array}$ \\
\hline 02:29 (A) & & & & Texto da canção. & $\begin{array}{l}\text { Coro (Iara } \\
\text { Rennó e outras } \\
\text { mulheres). }\end{array}$ \\
\hline \multicolumn{6}{|c|}{ a $R$} \\
\hline 00:10 (A) & & & Gritinho e fala. & "Ih" e texto falado. & $\begin{array}{l}\text { Uma (Iara } \\
\text { Rennó). }\end{array}$ \\
\hline 00:16 (A) & & Delay distorcido. & $\begin{array}{l}\text { Comentários } \\
\text { melódicos ou } \\
\text { falados, } \\
\text { repetindo } \\
\text { palavras da } \\
\text { melodia. }\end{array}$ & & $\begin{array}{l}\text { Três: principal, } \\
\text { segunda voz em } \\
\text { algumas } \\
\text { palavras e } \\
\text { comentários } \\
\text { (Iara Rennó). }\end{array}$ \\
\hline 00:32 (A) & & & & Vocalise "ahn". & $\begin{array}{l}\text { Coro como cama } \\
\text { harmônica } \\
\text { (outras } \\
\text { mulheres). }\end{array}$ \\
\hline 00:46 (B) & & & & Texto da canção. & $\begin{array}{l}\text { Coro (Iara } \\
\text { Rennó e outras } \\
\text { mulheres). }\end{array}$ \\
\hline
\end{tabular}




\begin{tabular}{|c|c|c|c|c|c|}
\hline 01:01 (B) & $\begin{array}{l}\text { Leve, com } \\
\text { registro } \\
\text { mais } \\
\text { próximo ao } \\
\text { de cabeça. }\end{array}$ & & & $\begin{array}{l}\text { Vocalise: "uh"e } \\
\text { "ahn". }\end{array}$ & $\begin{array}{l}\text { Coro (Iara } \\
\text { Rennó e outras } \\
\text { mulheres). }\end{array}$ \\
\hline 01:13 (B) & & & $\begin{array}{l}\text { Gritinho com } \\
\text { humor. }\end{array}$ & "Au". & $\begin{array}{l}\text { Uma (iara } \\
\text { Rennó). }\end{array}$ \\
\hline 01:15 (A) & & & $\begin{array}{l}\text { Adensamento } \\
\text { dos } \\
\text { comentários do } \\
\text { primeiro A } \\
\text { (pequenas } \\
\text { melodias, falas, } \\
\text { gritinhos, } \\
\text { gemidos, } \\
\text { glissandos). }\end{array}$ & & $\begin{array}{l}\text { Várias camadas } \\
\text { (Iara Rennó). }\end{array}$ \\
\hline 01:18 (A) & $\begin{array}{l}\text { Aspirado, } \\
\text { com ar na } \\
\text { voz. }\end{array}$ & & & $\begin{array}{l}\text { Célula rítmica: } \\
\text { "Takataka". }\end{array}$ & $\begin{array}{l}\text { Várias camadas } \\
\text { (Iara Rennó). }\end{array}$ \\
\hline 2:45 (A) & & & $\begin{array}{l}\text { Combinação de } \\
\text { vários } \\
\text { elementos } \\
\text { vocais que } \\
\text { passaram pela } \\
\text { música. }\end{array}$ & $\begin{array}{l}\text { Trechos do texto da } \\
\text { canção, vocalises e } \\
\text { célula rítmica } \\
\text { ("tcheguereguere"). }\end{array}$ & $\begin{array}{l}\text { Várias camadas } \\
\text { (Iara Rennó e } \\
\text { outras } \\
\text { mulheres). }\end{array}$ \\
\hline \multicolumn{6}{|c|}{ 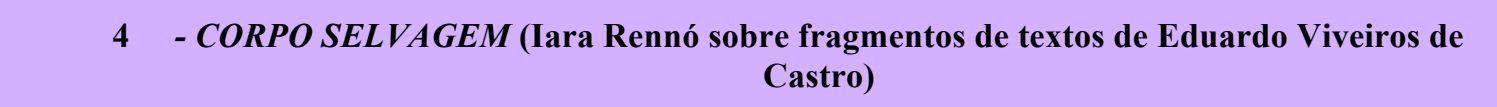 } \\
\hline 00:00 (A) & & Delay, phaser. & $\begin{array}{l}\text { Voz dobrando } \\
\text { oitava acima } \\
\text { em registro } \\
\text { muito agudo, } \\
\text { com dinâmica } \\
\text { bem baixa, } \\
\text { levemente } \\
\text { deslocada, } \\
\text { gerando efeito } \\
\text { de eco/sombra } \\
\text { com a primeira } \\
\text { voz. }\end{array}$ & Texto da canção. & $\begin{array}{l}\text { Duas vozes (Iara } \\
\text { Rennó). }\end{array}$ \\
\hline
\end{tabular}




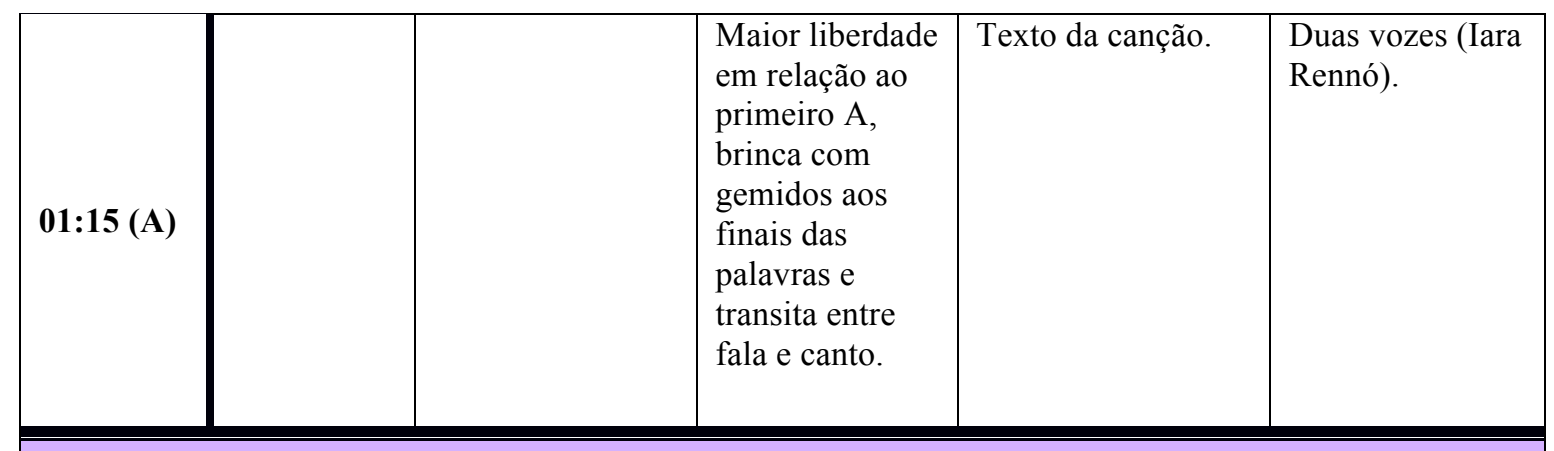

05 - VULVA VIVA (Iara Rennó, Alice Ruiz)

\begin{tabular}{|l|l|l|l|l|l|}
\hline \hline 00:03 (A) & $\begin{array}{l}\text { Anasalado, } \\
\text { agudo, } \\
\text { metálico, } \\
\text { alto e } \\
\text { frontal. }\end{array}$ & Delay. & & Texto da canção. & $\begin{array}{l}\text { Uma (Iara } \\
\text { Rennó). }\end{array}$ \\
\hline 00:49 (B) & & & & Texto da canção. & $\begin{array}{l}\text { Coro a três } \\
\text { vozes (Iara } \\
\text { Rennó e outras } \\
\text { mulheres). }\end{array}$ \\
\hline \hline
\end{tabular}

06 - O QUE ME ARDE (Iara Rennó, Alzira E)

\begin{tabular}{|l|l|l|l|l|l|}
\hline \hline 00:17 (A) & & Reverb. & & Texto da canção. & $\begin{array}{l}\text { Uma (Iara } \\
\text { Rennó). }\end{array}$ \\
\hline \hline
\end{tabular}

07 - MEUS VÃOS (Iara Rennó)

\begin{tabular}{|l|l|l|l|l|l|}
\hline \hline 00:00 (A) & $\begin{array}{l}\text { Anasalado, } \\
\text { agudo, } \\
\text { metálico, } \\
\text { alto e } \\
\text { frontal. }\end{array}$ & $\begin{array}{l}\text { Duplicação, } \\
\text { delay, phaser. }\end{array}$ & & Texto da canção. & $\begin{array}{l}\text { Uma duplicada } \\
\text { (Iara Rennó). }\end{array}$ \\
\hline $\mathbf{0 0 : 4 5 ~ ( A ) ~}$ & & $\begin{array}{l}\text { Duplicação com } \\
\text { passa alta. }\end{array}$ & & Texto da canção. & $\begin{array}{l}\text { Uma duplicada } \\
\text { (Iara Rennó). }\end{array}$ \\
\hline 2:36 (A) & & $\begin{array}{l}\text { Repetição de } \\
\text { vários gritos } \\
\text { rápidos da } \\
\text { palavra } \\
\text { "quero", em um } \\
\text { registro agudo. } \\
\text { Ao final há um }\end{array}$ & $\begin{array}{l}\text { Texto da canção } \\
\text { (“quero"). }\end{array}$ & $\begin{array}{l}\text { Uma (Iara } \\
\text { Rennó). }\end{array}$ \\
\hline \hline
\end{tabular}




\begin{tabular}{|c|c|c|c|c|c|}
\hline & & & $\begin{array}{l}\text { glissando } \\
\text { descendente e } \\
\text { ralentando até o } \\
\text { silêncio. }\end{array}$ & & \\
\hline \multicolumn{6}{|c|}{08 - NO SILÊNCIO (Iara Rennó) } \\
\hline 00:20 (A) & & & $\begin{array}{l}\text { Durante toda } \\
\text { música é } \\
\text { improvisado } \\
\text { um vocalise } \\
\text { sempre no } \\
\text { mesmo ritmo. }\end{array}$ & $\begin{array}{l}\text { Vocalise: } \\
\text { "papapa". }\end{array}$ & $\begin{array}{l}\text { Uma (Iara } \\
\text { Rennó) }\end{array}$ \\
\hline 00:43 (A) & $\begin{array}{l}\text { Um homem } \\
\text { fala com } \\
\text { voz grave. } \\
\text { Iara Rennó } \\
\text { fala } \\
\text { sussurrado. } \\
\end{array}$ & & & Texto falado. & $\begin{array}{l}\text { Duas vozes (um } \\
\text { homem e Iara } \\
\text { Rennó). }\end{array}$ \\
\hline 01:02 (A) & Sussurrado. & & & Texto falado. & $\begin{array}{l}\text { Entrada } \\
\text { gradativa de um } \\
\text { coro de } \\
\text { mulheres (outras } \\
\text { mulheres). }\end{array}$ \\
\hline \multicolumn{6}{|c|}{09 - DUELO (Iara Rennó) } \\
\hline 00:13 (A) & Doce. & Reverb. & & Texto da canção. & $\begin{array}{l}\text { Uma (Iara } \\
\text { Rennó). }\end{array}$ \\
\hline 00:38 (A) & & & & & $\begin{array}{l}\text { Entrada de uma } \\
\text { segunda voz na } \\
\text { terça, que varia a } \\
\text { melodia em } \\
\text { relação a } \\
\text { primeira voz } \\
\text { (Iara Rennó). }\end{array}$ \\
\hline
\end{tabular}

Fonte: tabela elaborada para este trabalho.

Na tabela pode ser notada a ampla utilização de recursos tais quais vocalises, gemidos, gritos, sussurros, trânsito entre fala e canto (este último se dá principalmente em Corpo Selvagem, na qual o texto provém dos trechos de Viveiros de Castro, em prosa). É utilizada uma ampla gama de timbres e efeitos eletrônicos na voz, também podemos notar 
uma certa constância em algumas escolhas, ou seja, o disco tem uma base sólida no que diz respeito a timbre e efeitos, porém a partir dessa base há variações.

As escolhas das maneiras de trabalhar a voz estão diretamente ligadas aos assuntos de cada música. Assim, Iara Rennó cria ambientes utilizando a voz. Por exemplo em Mama-me (faixa 01) a música é iniciada com a frase "Sonha que me despe e a festa acontece", então a música é trabalhada para criar esse clima festivo. Desde a escolha dos instrumentos - que envolve o clarone, guitarra, bateria, percussão eletrônica, sintetizador, com ampla utilização de pedais e efeitos eletrônicos - até os recursos vocais - como a escolha dos timbres, e utilização de gritinhos e glissandos - atuam de maneira a criar o ambiente de festa. Já a letra da música Sonâmbula é bastante humorada, em que Iara Rennó explora sons engraçados, performando assim a música por meio da voz. Nesta música, inclusive os instrumentos, fazem sons que reportam ao humor, tal qual glissandos, dentre outros.

No geral, o disco trabalha com uma energia bastante alta e densa: são exploradas várias sonoridades diferentes ao mesmo tempo, muitas vezes polifonicamente e a dinâmica aparece em geral mais alta. Porém na música $O$ que me arde (faixa 07) há um momento de contenção na energia, em que são utilizados poucos elementos e efeitos e os timbres e dinâmica aparecem mais suaves, causando uma impressão de recolhimento. Esta é justamente a primeira música do disco com uma temática mais voltada a uma reflexão interna. Após essa faixa aparecem ainda mais duas músicas com esse caráter (No silêncio e Duelo), que são as faixas finais do disco. Dessa maneira, Iara Rennó entrelaça as palavras e a sonoridade em Arco, criando ambientes que dão a curva energética de seu disco, que inicia em momentos mais explosivos e finaliza em momentos de busca por reflexão interna.

A preocupação da artista com uma concepção material do corpo é explorada tanto no âmbito da sonoridade quanto da escrita. Por exemplo na música No silêncio (faixa 08), em meio a vocalises e instrumentação com poucos elementos, é falado o texto "No silêncio áspero de nossos pelos, o acordo tácito de nossas peles" (RENNÓ, p. 44, 2016). Nessa faixa há a participação de um homem cantando, que fala o texto de maneira sensual, 
sussurrada e grave, junto a um coro de mulheres. Além da textura criada por esse coro de sussurrantes, os instrumentos exploram recursos que trazem as sensações para um primeiro plano. Quase não são utilizados efeitos eletrônicos, portanto a exploração de texturas vem por outros meios, por exemplo, durante um tempo o clarone solta apenas ar, como se fosse uma respiração, e é utilizada uma vassourinha esfregada na caixa da bateria com esteira aberta. Tais recursos trazem o parâmetro da textura para um primeiro plano, criando a ambiência para cantar a letra da música.

Já no âmbito da escrita da artista, a materialidade é explorada pela utilização de recursos que - como no âmbito da poesia sonora trabalhada por Flora Holderbaum trazem à tona valores expressivos da vocalidade.

Diferente do trabalho de Flora Holderbaum - que busca um deslocamento do foco semântico das palavras para a musicalidade inerente à língua e à corporeidade - na poesia de Iara Rennó tais recursos agem juntos com o sentido semântico, em um movimento de corporalização das palavras, que articulam semântica e corpo. Por exemplo, na música Mama-me é descrito um ato sexual heterossexual:

Sonha que me despe

E a festa acontece

Sem roupa nem confete

Só carne

Com a carne se veste

Se isso lhe apetece

Rasga essa fantasia

Sacia essa sede

Até dissolver-se em mim

Me veste me desfila

Me fia me confia

Seu coração em chamas

Me chama

Me acende e ascende em $\mathrm{mim}$

Mama-me me mama ê ô ô

Morde meu cangote

Galopa o meu galope

Lê minha partitura

Com sua parte dura

Perfuma perfura

Penetra meus poros 
Enquanto eu evaporo

Na noite mais escura

(RENNÓ, 2015, p. 46, 47 $7^{42}$ )

No texto o eu-lírico feminino fala diretamente para uma pessoa do sexo masculino. Trata-se de um poema erótico, no qual as sensações são trazidas a um primeiro plano e, para causar tal efeito, no poema é utilizado por exemplo o recurso linguístico da aliteração, como nos trechos:

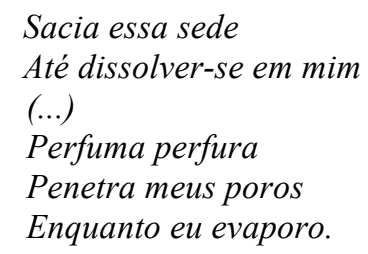

Tal recurso traz o foco - para além do sentido semântico das palavras - para os sons da língua produzidos na boca, a partir da garganta de carne. Portanto as aliterações conferem corporeidade e materialidade aos textos, de modo que tal materialidade corpórea se apresenta tanto no âmbito da criação, quanto no âmbito da leitura e performance dos poemas.

\footnotetext{
${ }^{42}$ Poema publicado originalmente no livro língua brasa carne flor, sob o título que $m$ ama $m$ ama. Na canção foi acrescentado o verso "mama-me e ô ô ô" e foi retirado o segundo verso da última estrofe do poema original: "Me amarra nesse poste".
} 
Figura 10 - frames do clipe de Mama-me, (RENNÓ, 2016).

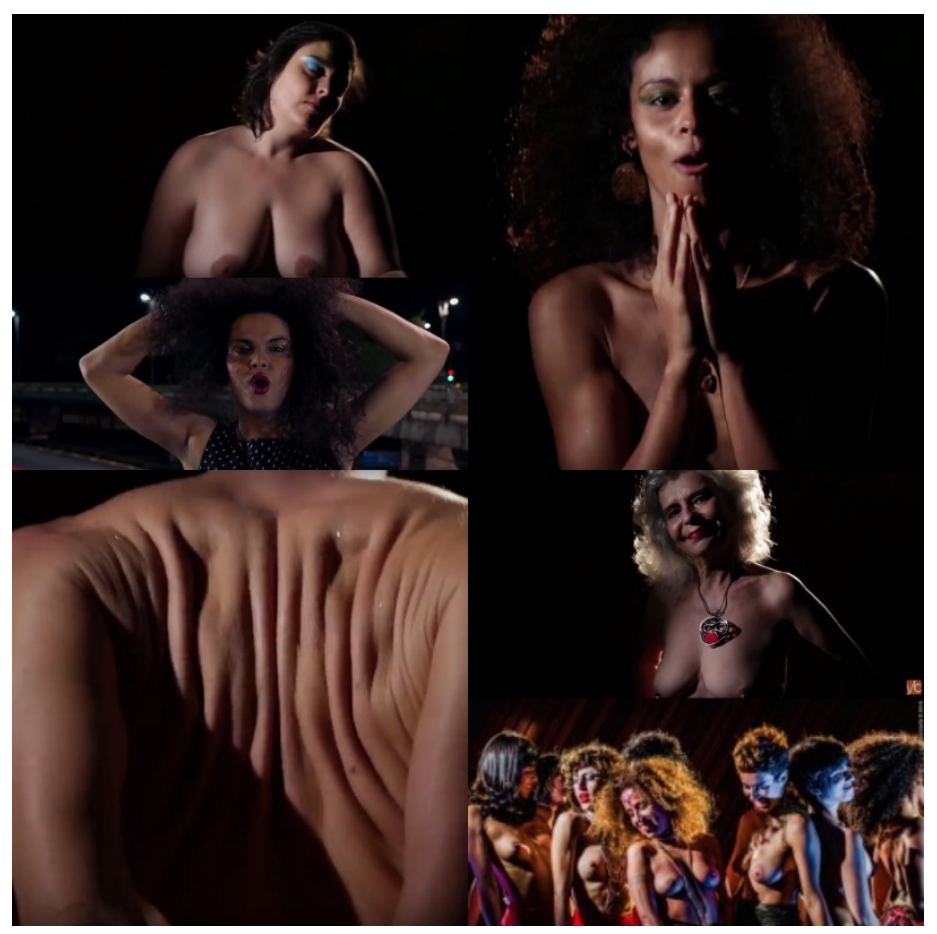

Fonte: quadro realizado para este trabalho ${ }^{43}$.

Portanto Iara Rennó envolve seus textos eróticos em uma sonoridade musico-vocal que traz o corpo em um primeiro plano. Tal corporeidade é também amplamente explorada nas performances de seus shows e vídeo-clipes.

\subsection{Considerações finais do capítulo}

Um dos pontos abordados por Silvia Federici em seu livro é a relação estabelecida - na linguagem da caças às bruxas - entre as bruxas e os animais.

Numa época em que se começava a adorar a razão e a dissociar o humano do corpóreo, os animais também foram submetidos a uma drástica desvalorização - reduzidos a simples bestas, ao "Outro" definitivo -, símbolos perenes do pior dos instintos humanos. Nenhum crime, portanto,

\footnotetext{
${ }^{43}$ Quadro realizado a partir de frames do clipe disponível em: www.youtube.com/watch?v=Ru-IeOXxGgg
} 
seria capaz de inspirar mais aversão do que a cópula com uma besta, um verdadeiro ataque aos fundamentos ontológicos de uma natureza humana cada vez mais identificada com seus aspectos imateriais. No entanto, o excesso de presenças animais na vida das bruxas sugere também que as mulheres se encontravam numa encruzilhada (escorregadia) entre os homens e os animais, e que não somente a sexualidade feminina, mas também a sexualidade como tal, se assemelhava à animalidade (FEDERICI, 2017, p. 349).

Iara Rennó aproveita em Arco a concepção de um corpo material observado por Viveiros de Castro em culturas indígenas, na qual a relação entre humano e animal é estreita, como exemplificado no verso: "Ocultar uma essência humana sob uma aparência animal" (RENNÓ, faixa 04, 2016; CASTRO, 1996, p. 128). Além disso, na contracapa do livro carne brasa língua flor, a escritora Alice Ruiz destaca sensações voltadas para o caráter animalesco que a leitura traz:

\footnotetext{
...ela prefere jogar a mulher que ela é, a mulher que a mulher é, quando fêmea, na cara de quem lê. Totalmente sem-vergonha: Louvadas sejam as deusas por isso. Porque isso é o que há de mais feminista (Alice Ruiz, sobre Iara Rennó, língua brasa carne flor, 2015, grifo nosso).
}

Nesse sentido, Iara Rennó se apropria do discurso hegemônico - que delimita o feminino na esfera do corpóreo - para assim subvertê-lo. Portanto em Arco a artista reafirma a relação do feminino com o corpóreo, - ilustrado aqui pela sua relação com os instintos, o animalesco - mas, em um movimento de inversão, uma vez que as sensações do corpo não estão rebaixadas, mas participam do ser, que é material, corpóreo. Além disso, a noção de feminino também é subvertida, pois está em fluxo.

A semântica, nesse sentido, é articulada e ressignificada por um corpo ativo. Não é à toa que Alice Ruiz destaca que se impor enquanto "fêmea" é um ato feminista, já que tal ato, nesses termos, vem trazer valores materiais do sujeito, subvertendo o paradigma cartesiano que rebaixa os sentidos - relegados às mulheres - em detrimento da mente, relegada aos homens.

Nessa visão feminista é necessário, portanto, reivindicar o corpo para que se organize o mundo a partir dele. Nesse aspecto, Iara Rennó o faz em Arco, valendo-se da temática da sexualidade (não reprodutiva) das mulheres, tabu que - em tempos não muito 
distantes - condenaram centenas à fogueira. Dessa maneira é como se a artista se assumisse enquanto bruxa que reivindica o corpo e os instintos humanos para assim apropriar-se do discurso hegemônico e subvertê-lo. Para tanto, Iara Rennó utiliza sonoridades e recursos vocais que trazem o corpo para o plano encarnado, em um movimento de expandir e romper as imposições delimitadas pelo discurso patriarcal e capitalista.

Assim, em um ato artístico, posicionar-se enquanto mulher pode ser um ato subversivo. Ao situar-se enquanto corpo em suas canções a artista revela suas singularidades e o ponto de vista de onde fala, opondo-se à ideia de neutralidade. Para Maria Xosé Queizán, por exemplo, “A Literatura Feminista significa tomar a palavra conscientemente como mulher. Ao fazer isto, o universal masculino deixa de refletir toda a realidade" (Queizán, 2000, p. 104, tradução nossa ${ }^{44}$ ).

Iara Rennó utiliza-se então das palavras e sonoridade vocal-instrumental para apropriar-se do corpo como espaço discursivo. Dessa maneira, a artista confere visibilidade ao corpo e participa de uma recodificação dos espaços simbólicos, essencial para subverter as estruturas.

\footnotetext{
44 “A Literatura Feminista significa tomar a palabra conscientemente como muller. Ao facer isto, o universal masculino deixa de reflexar toda a realidade” (Queizán, 2000, p. 104).
} 


\title{
CAPÍTULO 4 - PERFORMANCE NA MÚSICA: FUNÇÕES E MODOS DE VEICULAR AS CRIAÇÕES
}

\subsection{A performance na música e musicologia: questões sobre práticas musicais}

Em seu texto Gênero, Música e Feminismo, Suzanne Cusick discute a relação de reforço mútuo entre a musicologia tradicional e a música absoluta. Para a autora:

\begin{abstract}
... a musicologia, feita à imagem e gosto do 'homem' moderno, (...) reforça constantemente a supremacia de uma música que se assemelha em sua autonomia a imagem e gosto do 'homem' moderno. A musicologia e a música absoluta - música que é, como a musicologia, autônoma e livre - portanto se encontram enquanto iguais, reforçando o prestígio uma da outra ao se definirem em oposição ao [que é considerado] culturalmente feminino (CUSICK, p. 481, 1999, tradução nossa ${ }^{45}$ ).
\end{abstract}

Nessa perspectiva, a autora discute como a musicologia tradicional - desenvolvida no âmbito de discursos hegemônicos - reforça a ideia da música absoluta, autônoma da esfera social e proclamada por tal discurso como a "'maior” forma de música” (CUSICK, p. 481, 1999). Em tal concepção a forma da música - elaborada e escrita pela figura de um gênio homem e branco - é posta em primeiro plano e assim a música é relegada ao plano da mente/razão. Nessa abordagem não apenas as relações sociais são desconsideradas, mas com elas os corpos que participam das atividades musicais.

Portanto, a abordagem musicológica tradicional criticada por Suzanne Cusick reforça o paradigma cartesiano, uma vez que foi fundada por homens brancos europeus, que pretendem manter sua hegemonia ao corroborar com a ideia de uma música absoluta em que, ao passo que o caráter corpóreo da música é negado, é elevada tanto à ideia da obra musical quanto à figura do gênio compositor.

A perspectiva da performance vem romper tais hierarquias reforçadas pela musicologia tradicional. De acordo com Nicholas Cook:

\footnotetext{
45 “... musicology, made in the image and likeness of modern 'man', matches and reinforces constantly the supremacy of music that resembles in its autonomy the image and likeness of modern 'man'. Musicology and absolute music - music that is, like musicology, autonomous and free - thus meet as equals, reinforcing each other's prestige as defined in opposition to the culturally feminine" (CUSICK, p. 481, 1999).
} 
Construída a partir da visão da teoria crítica como um ato de resistência contra a autoridade e enclausuramento do texto reificado, a causa da performance se torna um veículo para reabilitar os interesses dos marginalizados pelo discurso musicológico tradicional (COOK, 2011, p. 4, tradução nossa ${ }^{46}$ ).

Tal tradição musicológica citada por Nicholas Cook é fundada na ideia de um corpo neutro e universal, que afinal tenta manter a hegemonia. Dessa maneira, o corpo singular e encarnado - é fundamental para se pensar uma nova musicologia em que sejam discutidas e subvertidas as hierarquias presentes na música. Portanto a perspectiva da performance na música se contrapõe à cultura da hegemonia da escrita musical, na qual a obra musical configura-se enquanto auge da música, paradigma que prioriza a criação (mente) em detrimento da interpretação (corpo).

Ao ampliar o estudo musicológico para além da escrita outras perspectivas emergem e podemos pensar em um âmbito da música em que não são hierarquizadas as relações de gênero, raça, classe e, portanto, os estilos musicais. No contexto da Nova Musicologia - que abarca a musicologia feminista - é proposto, portanto, que se estude a música considerando todo seu contexto e relações sociais, ou seja, a música enquanto prática, performance. Nessa perspectiva, a performance - compreendida enquanto ação material - abarca toda a prática musical, desde sua criação à apresentação, e assim a hierarquia da escrita, e consequentemente da obra musical, perde o sentido.

Portanto, no contexto da Nova Musicologia - adotada por este trabalho - ao considerarmos as práticas musicais enquanto performance, tanto a figura do gênio compositor, quanto a ideia de obra e cânone musical, são diluídos. São des-hierarquizadas tanto questões de estilos musicais, quanto de funções nas práticas musicais. Nesse contexto é possível, como propomos neste trabalho, estudar, a partir de uma mesma perspectiva, artistas de diferentes estilos, gerações e renomes.

A discussão sobre a forma como são veiculadas as criações musicais (se escritas, ou não) abarca o debate sobre as relações sociais e as funções das artistas envolvidas em cada contexto. Cada artista estudada nesta pesquisa tem diferentes funções e meios de

\footnotetext{
46 "Construed in the manner of critical theory as an act of resistance against the authority and closure of the reified text, the cause of performance becomes a vehicle for rehabilitating the interests of those marginalized by traditional musicological discourse" (COOK, 2011, p. 4).
} 
transmitir suas criações. Jocy de Oliveira é compositora de música contemporânea e veicula sua criação valendo-se de partitura escrita. A artista também fez a direção artística do DVD analisado, em que Katia Guedes e Gabriela Gerluda performam. No caso de Flora Holderbaum a artista é performer e participa de todas as etapas, desde a criação à execução. A artista me contou em conversa que tem trabalhado na elaboração de uma partitura para 5 peças para Microvocalidades. Iara Rennó, por sua vez, participa de todas as etapas de seu disco e os arranjos são coletivos, criados em conjunto no ato da gravação. Portanto, cada maneira de envolvimento e funções desempenhadas pelas artistas em seus trabalhos ocorre de acordo com o contexto de suas práticas musicais.

Vale notar que de alguma maneira as três artistas partem de um material escrito: Flora Holderbaum compõe a partir de experimentações vocais de seu poema - gravadas em estúdio - com o intuito de discutir vocalidades; Jocy de Oliveira estrutura sua composição escrita utilizando textos ligados ao universo de Ofélia e não é a compositora quem performa a peça, mas sim Kátia Guedes e Gabriela Gerluda, que enquanto cantatrizes estão emolduradas pela noção de teatralidade, e é neste espaço criado com o público que inscrevem seu canto- performance; Iara Rennó, pelo menos em alguns casos, compõe suas músicas a partir de seu livro de poemas eróticos.

Nesse aspecto, as singularidades são trabalhadas de maneiras distintas pelas artistas. Se no caso de 5 Peças para Microvocalidades é a mesma artista que escreve o poema, experimenta a voz e compõe as micropeças, em Ofélia presa nas cordas do piano as funções estão distribuídas e a elas é acrescentada a interferência das personagens, que se desdobram pelo uso da metalinguagem. A singularidade neste segundo caso em que há uma partitura a ser seguida, se inscreve por meio das vocalidades, que evidenciam a corporeidade tanto das artistas - no momento da performance ${ }^{47}$ - quanto das personagens. Nesse sentido, os aspectos vocálicos-performáticos transitam entre a escritura e a

\footnotetext{
${ }^{47}$ Vale lembrar que assisti ao vídeo da ópera em DVD, portanto não estive presente na performance no teatro. Porém, ainda assim, no momento em que assisti participei do fluxo, enquanto espectadora, ao administrar informações e escrever sobre elas neste trabalho. Portanto a performance acontece sempre que o DVD é assistido, pois o fluxo de informações ocorre e é diferente de acordo com cada pessoa espectadora e contexto em que se assiste, levando a diferentes resultados.
} 
performance da peça e trazem à tona a subversão da linguagem e do discurso patriarcal tradicionalmente previsto no universo da ópera.

Como Flora Holderbaum nas 5 peças para Microvocalidades, em Arco, Iara Rennó inscreve sua singularidade em vários níveis, já que concentra em sua prática criação e execução. Ambas têm em comum ainda a criação no ato de gravar. Porém, no caso de Iara Rennó, esse momento é coletivizado, por se tratar de arranjos criados em grupo.

Ao definir-se enquanto performer no âmbito da Poesia Sonora, Flora Holderbaum também põe em jogo as relações hierárquicas na música. Para Paul Zumthor:

A Poesia Sonora de abre em performance. (...) Desse modo, diversificando também aqui temperamentos e hábitos, os poetas sonoros "se põem no espetáculo" numa cena que constitui um território intermediário entre poesia, música, dança, pintura, unidas por um ritual no qual se fundam em feixes expressivos controlados pelo primado de um corpo sonoro. Ser um “performer, para um autor, é tornar-se intérprete de si mesmo, é retroceder um pouquinho na orgulhosa hierarquia estabelecida há alguns séculos por nossos literatos. No limite, a noção mesma de autor se dissipa: o acento se desloca para a própria performance, na sua unicidade, na sua não-repetibilidade, na sua individualidade acústico-visual, que faz do ouvinte-espectador um co-produtor da obra proposta à sua atenção (ZUMTHOR, 1992, p. 143).

Portanto, a perspectiva da performance, seja no âmbito da música, do estudo da performance, ou da performatividade, vem trazer as ações para um primeiro plano, de maneira a tratar os sujeitos - estejam eles performando seu gênero, uma música, ou uma performance artística - de forma material, produtores de materialidade. No âmbito da música não seria diferente: na perspectiva da performance a música passa de uma ideia absoluta, autônoma e celestial para o concreto, matéria feita a partir de corpos materiais.

\subsection{Trânsito entre práticas: relato de uma trajetória}

A perspectiva da performance traz para a pesquisa musicológica uma preocupação com todas as fases que envolvem a música, passando pelo momento de criação e apresentação, mas também pelas fases anteriores - que dizem respeito à construção das singularidades de artistas participantes - e pelo que virá em momento posterior - que se reporta ao que o público e quem performa carrega consigo da performance. 
Pensar uma pesquisa musicológica nesse âmbito, como é o caso deste trabalho, significa também imprimir o corpo da pesquisadora em questão. Nessa perspectiva, é necessário realizar uma abordagem em que a autoria não se caracterize enquanto neutra. Assim como a musicologia tradicional reforça a ideia de uma música absoluta, aqui - no âmbito da musicologia que pensa a música enquanto performance - a própria pesquisa é concebida como tal.

Nesse aspecto, trago um pouco de minha trajetória artística como maneira prática de abordar os assuntos desta pesquisa. Dessa forma me inscrevo enquanto artista pesquisadora e trabalho o fluxo entre estudo e prática. Afinal o estudo também encontrase no plano da ação e da performance.

Em minha trajetória artística, a tentativa de resolver o paradigma da "música escrita versus música não escrita” tem estado presente em vários níveis. A educação musical adquirida - desde os conservatórios de Goiânia, até a graduação em composição na Universidade de São Paulo - parecia não abarcar minha trajetória musical que se iniciou nos palcos underground goianos.

Por muitos anos, a prática intuitiva de compor canções populares parecia completamente apartada do aprendizado de educação musical que, na academia, incluía a composição no âmbito da música contemporânea e experimental.

A tentativa de resolver essa visão segmentada esteve presente em minha trajetória a ponto de discutir o assunto em meu Trabalho de Conclusão de Curso-TCC da graduação em Composição, intitulado A fala goiana: aspectos da música popular e erudita (ALVES, 2015). Sempre atenta aos movimentos de música popular no Departamento de Música da ECA-USP, pude notar poucos casos em que tal universo era abordado. Os raros estudos apresentados em TCC do curso de Composição que abordavam assuntos da música popular que presenciei foram os de dois colegas (homens) que pareciam garantir seu espaço se utilizando de argumentos trazidos da música de concerto. Ou seja, o espaço da música popular nunca esteve garantido nos âmbitos da educação musical que frequentei.

Podemos concluir que a visão de obra musical - que eleva a música escrita e desconsidera questões cruciais para a música, tais quais gênero, raça, classe e estilos 
musicais - não está alocada em um passado distante, que parte de uma musicologia tradicional já superada. Pelo contrário, "a música" ensinada nas instituições continua abarcando poucos estilos, as mulheres continuam distantes do curso de composição e as pessoas negras e pobres continuam tendo que provar seu valor no universo da música de concerto.

Mas em que aspectos este assunto encontra consonância com um trabalho que se propõe a discutir questões da voz a partir de uma perspectiva de gênero?

Sendo mulher cantora e compositora - que teve sua trajetória artística marcada até agora pelo trânsito entre estilos - pesquiso, tanto no âmbito teórico, quanto em minha prática artística mulheres que criam com vozes ${ }^{48}$. Com certeza o maior impacto de minha pesquisa em minha prática artística encontra-se na descoberta de caminhos que possam finalmente atrelar o universo de minha educação musical direcionada para música escrita e experimental, com minha criação artística, que se conecta a aspectos de minha singularidade, tais quais o gênero e minhas raízes culturais.

Tal impacto implica a descoberta de que a música - independentemente do estilo em que se inscreve - pode ser organizada através do corpo em minhas práticas artísticas. Entre alguns exemplos que abarcam tal descoberta, escolhi relatar o mais recente, do grupo Teatro Labirinto, o qual integro desde junho de 2018, no projeto Canto para o jardim de veredas, contemplado pelo PROAC 2019 e ainda em processo ${ }^{49}$.

\subsection{Canto para o jardim de veredas, grupo Teatro Labirinto}

O grupo Teatro Labirinto, formado por seis atrizes/cantoras, surgiu no intuito de investigar o canto como ato criador. Reunido pela diretora do processo Giu de Castro, o grupo desenvolve coletivamente um espetáculo nas fronteiras entre teatro e música ${ }^{50}$.

\footnotetext{
${ }^{48}$ No ANEXO 1 está um quadro das atividades artísticas que desenvolvi durante o processo do mestrado. Tais atividades acontecem em consonância com o trabalho de pesquisa.

${ }^{49}$ O PROAC é o Programa de Ação Cultural do Estado de São Paulo, edital no qual o governo oferece a empresas contribuintes do imposto ICMS a proposta de patrocinar a produção artística e cultural de São Paulo, apoiando financeiramente projetos credenciados pela Secretaria de Estado da Cultura.

${ }^{50}$ As cantoras/atrizes do espetáculo Canto para o jardim de veredas são: Alice Máximo, Camilla Veles, Carolina Braga, Giu de Castro, Maitê Arouca e Sarah Alencar.
} 
Figura 11 - Abertura de processo do Canto para o jardim de veredas, no V Encontro de Teatro Universitário.

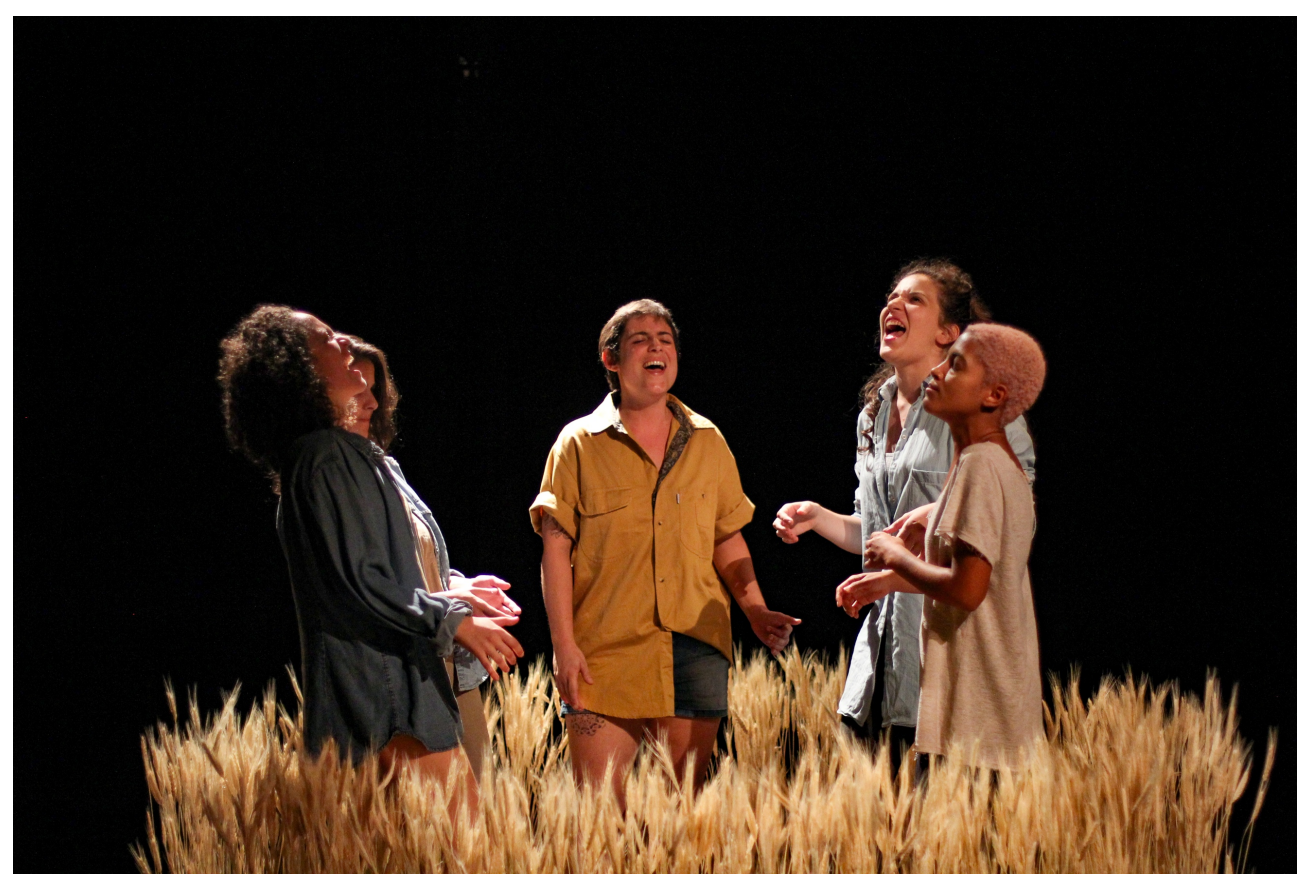

Fonte: fotografia de Gabriel Goes.

Do início do processo até o final de 2018 trabalhamos propostas criativas a partir do conto O jardim de veredas que se bifurcam (BORGES, p. 80- 93, 2007). Separamos o conto em partes e todas as integrantes do grupo criaram materiais a partir dos fragmentos. Assim foram criados procedimentos, cenas e músicas. Diferente de mim, as outras integrantes do grupo têm formação em teatro, assim, minhas funções incluem maior envolvimento na elaboração de arranjos musicais e preparação vocal.

Portanto neste processo as criações são realizadas de forma coletiva, embora haja funções nas quais cada participante esteja mais engajada - de acordo com sua singularidade - e a figura da diretora esteja presente, função fundamental para amarrar os materiais e dar rumo consistente para o processo.

O ambiente e funções do contexto do teatro são diferentes do campo da música. Porém, como se trata de um espetáculo em que o processo criativo parte do canto, é importante averiguar como se dão as funções nesse âmbito. Nesse aspecto, em nosso 
processo todas são compositoras e performers, assim as hierarquias são dissolvidas, uma vez que todas são criadoras e parte intrínseca do projeto.

Utilizamos tanto partituras quanto gravações como veículo de nossas criações. As partituras auxiliaram especialmente para esclarecer fórmulas de compasso e momentos de entradas das vozes. Por exemplo, levei a proposta do Cânone das ressonâncias para o grupo no final de 2018. O cânone é a música de abertura da peça. 
Partitura 5 - Cânone das ressonâncias.
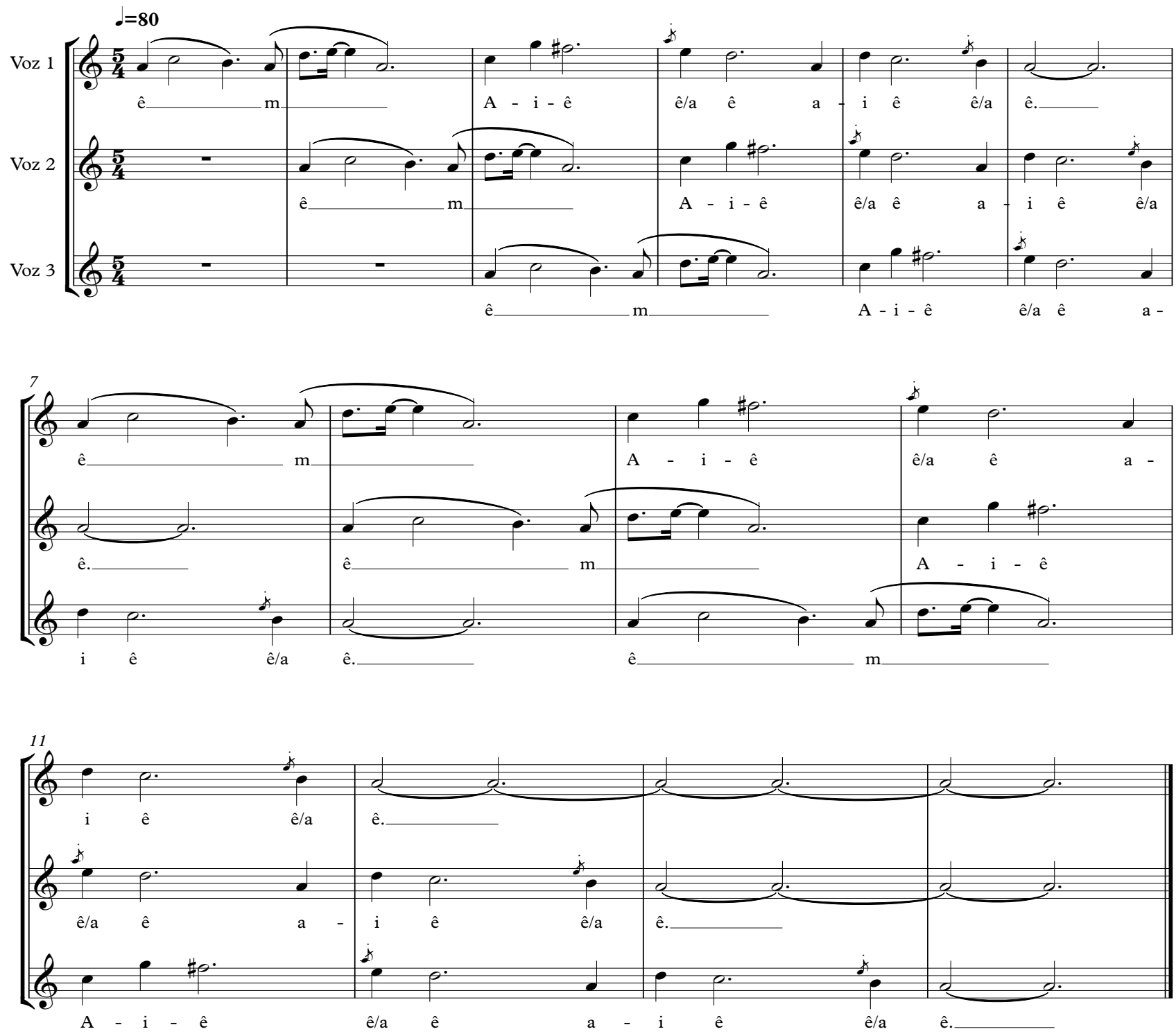

Fonte: partitura elaborada pela autora.

Como se trata de uma música em 5/4, a partitura foi importante para o grupo visualizar a fórmula de compasso e entender as entradas das vozes. Nessa música fizemos 
um trabalho bastante focado em timbres e recursos vocais. Com duas atrizes/cantoras em cada voz, chegamos a um resultado timbrístico no qual cantamos de maneira bastante metálica e frontal, com dinâmica forte (timbre que apelidamos de "lavadeiras"). Também trabalhamos quebras de voz com golpes de glote em trocas de nota. Performada desta maneira a música causa bastante impacto e serve como base energética para o desenrolar da peça.

A harmonia da música é trabalhada com bastantes dissonâncias formadas por intervalos de segunda maior (2M). Esse recurso é muito utilizado de maneira geral nos arranjos das músicas da peça. Para trabalhar a afinação das dissonâncias nessa música por exemplo, a escolha timbrística foi fundamental.

Desde o início do processo o livro Vozes plurais: filosofia da expressão vocal, da Adriana Cavarero serviu de base conceitual para nosso trabalho. No âmbito do teatro, assim como na filosofia, o discurso logocêntrico se desdobra no paradigma "palavra versus corpo". Sendo mulheres criando a partir do canto, nos interessamos por maneiras de nos expressar que não partissem da palavra, apesar da semântica também estar presente no processo. Após muita discussão sobre o assunto, chegamos a soluções para diluir o dualismo e pensar um trabalho que parte do corpo-voz, mas também que envolvessem palavras ditas.

No enredo as seis mulheres estão presas em um campo de trigo infinito, no qual trabalham e buscam maneiras de escapar. Neste espaço-tempo, no qual as mulheres estão aprisionadas, elas se comunicam por meio do canto, já que - assim, como às Sereias, como aponta Adriana Cavarero em sua análise - a semântica lhes foi negada. Dessa maneira, quando há inserção de texto falado, há atrizes que representam a cena, enquanto outras fazem as falas no microfone, fora de cena. Ao passo que estão aprisionadas no canto, esta é sua forma de comunicação e a forma de expressão de suas singularidades. Portanto são explorados cantos que trazem ao primeiro plano a sensação da "garganta de carne".

Trazer o microfone para o espetáculo foi fundamental, tanto para resolver a questão da utilização de palavras, quanto para que pudéssemos ampliar a gama de sonoridades exploradas. Como Flora Holderbaum em 5 peças para Microvocalidades, 
com o microfone pudemos trabalhar sons mínimos, como estalos da saliva no dente, os dentes batendo, a saliva descendo pela garganta, fries etc.

Para trabalhar tais sonoridades tivemos como referências as artistas Juçara Marçal, Meredith Monk, Television Female Vocal Choir ( $O$ mistério das vozes búlgaras), Lenna Bahule, Iara Rennó, Flora Holderbaum, Jocy de Oliveira, Tanya Tagaq etc. As referências foram levadas por todas do grupo e tocadas aos inícios dos ensaios nos aquecimentos, ou utilizadas em propostas criadas pelas participantes.

Vale notar que no âmbito da instrumentação o processo foi iniciado apenas com vozes. Depois tivemos a participação de uma guitarrista, que acabou não se estabelecendo no processo e atualmente estamos trabalhando com a percussionista Camila Midori. A percussão vem colaborar tanto em uma sonoridade, que frisa a escuta textural, quanto em uma base rítmica para a peça.

A preocupação com timbres e textura está ligada à escolha de tratar o canto enquanto ato criador, que parte de corpos singulares. Diferente do que se trabalha no âmbito tradicional do teatro - que normalmente desenvolveria a peça a partir de uma dramaturgia - propomos a construção da dramaturgia a partir do canto. Nesse aspecto o enredo está sendo elaborado a partir das músicas e sonoridades que criamos. Dessa maneira as singularidades das atrizes emergem de sua criação.

Nesse âmbito, a peça envolve tanto cantos que trabalham alturas definidas, a partir de uma perspectiva melódica e harmônica, quanto momentos que trazem recursos vocais que exploram a corporeidade das participantes, com foco em ruídos. Por exemplo, o trecho da peça a seguir, denominado Composição dourada, foi criado por Giu de Castro a partir de textos que escrevemos em fluxo no ensaio sobre as razões para integrarmos o grupo.

\section{SILÊECIO.}

CAMILLA: Doooooooouraaaaaaaadooooo 1. Dourado 2. Dourado 3. Dourado 4. Dourado 5. Dourado 6. Dourado 7. Dourado 8. Dourado 9. Dourado 10......

NOVOS SONS SE INCORPORAM. LOOPINGS. PENSAR JUNTAS QUE SONS SÃO ESSES

ALICE (TRAVANDO NAS CONSOANTES) Olha que engraçado, gente. Que curioso. Que coisa. Que coisa. Sabe quando você vê 
algo todo o dia, sempre do mesmo jeito, sempre no mesmo lugar, que você para de perceber que a coisa existe?

CAROL $-\tilde{A H}$

ALICE - Tipo um vaso na sua mesa. Um quadro. Um buraco na parede. Que se incorpora ao cenário como se fosse a natureza?

CAROL $-\tilde{A H}$

MAITE $-\tilde{A H}$

ALICE-Sempre esteve ali, nasceu ali, viveu ali e ali vai ficar aí puf você para de perceber que a coisa existe

CAROL $-\tilde{A H}$

$\boldsymbol{M A I T E}-\tilde{A} H$

$\boldsymbol{S A R A H}-\tilde{A H}$

ALICE - Ai, olha que coisa que coisa, num belo dia, um dia normal, sem premonições nem símbolos, sem razão aparente, sem por que, por sabe-se lá quais conexões do seu cérebro você olha pro vaso, que sempre esteve ali, nasceu ali e vai estar pra sempre ali... e fala nossa um vaso

SARAH - nossa um vaso

TODAS - nossa um vaso

ALICE - Então

CAROL $-\tilde{A} H$

MAITE $-\tilde{A} H$

$\boldsymbol{S A R A H}-\tilde{A H}$

ALICE - Aconteceu isso comigo hoje. Até hoje eu nunca tinha notado aqueles moinhos. Vocês já tinham percebido aqueles moinhos?

TODAS PARAM SOM E MOVIMENTO. OLHAM PARA A DIAGONAL. FICA APENAS

CAMILLA: Dourado 30. Dourado 31. Dourado 32...

VOLTAM AO SOM BASE

SARAH - (FAZ RUÍDOS. GARGAREJOS. BARULHOS. CANTO

COM O CORPO.) O SOM VEM TÃO DE DENTRO QUE (SONS

RUIDOS GARGAREJOS BARULHOS - ESTUDAR ISSO)

(CASTRO, 2019).

Esse trecho da peça, ao passo que é caracterizado por ser verborrágico - já que é um momento com bastantes falas -, também se caracteriza enquanto música, já que é construído em cima de uma base de loops e pensado enquanto sonoridade. A maneira com que a criação foi veiculada se configura em uma espécie de "enredo-partitura". Nesse aspecto as fronteiras entre música e teatro são fluidas e o resultado performático pode ser caracterizado enquanto uma espécie de "música dramatúrgica". 
Portanto, a Composição dourada demonstra o envolvimento pleno das singularidades das participantes, uma vez que as palavras foram criadas a partir de textos escritos por nós, sobre nossas vontades. Além disso, temos momentos de solos improvisados, gerados por recursos que exploramos durante os ensaios, como demonstram as partes grifadas do texto, que são observações de ensaio. Optei por mantêlas no exemplo para expor os processos criativos do grupo, que tem como procedimento comum gerar materiais a partir da criação de uma pessoa, porém os graus de abertura para improviso variam e a maioria dos materiais acabam sendo gerados coletivamente.

A criação coletiva também resulta no trabalho com estilos diversos. Ao passo que trabalhamos sonoridades que se aproximam da música contemporânea -com a utilização de ruídos etc - são trabalhados ritmos e outros aspectos ligados à música popular, como ocorre por exemplo na música Festa. Este é um caso particular, no qual criamos a cena antes de criarmos a música. Tínhamos em mente uma cena festiva e o grupo me solicitou que eu compusesse a música para essa cena. Iniciei o trabalho anotando em meu caderno de criações algumas características do que estava em meu imaginário em relação à cena. A imagem de mulheres confraternizando através do canto, no meio de um campo de trigo me remeteu a uma espécie de "festa das bruxas". De maneira geral o tema da solidão vinha aparecendo muito no processo e este é um momento oposto, de comunhão, um expurgo, que, ao passo que remete à felicidade, também carrega um certo mistério.

Busquei em minha memória algumas referências musicais que me remetiam à festividade e mistério. Dentre outros exemplos que me lembrei do pessoal do Clube da Esquina, o final da música $O$ que foi feito devera (de Vera) (BORGES, BRANT, NASCIMENTO, 1978) - do disco Clube da Esquina 2 (NASCIMENTO, 1978) - me pareceu bastante próximo do eu imaginava para a cena. Ao final dessa canção há uma sessão instrumental bastante rítmica, com vocalises de Elis Regina e Milton Nascimento, procedimento bastante usual nas músicas do Clube da Esquina.

Utilizei vários procedimentos do trecho final dessa música para desenvolver a Festa. A primeira questão trabalhada foi o ritmo. Em conversa com a percussionista Camila Midori chegamos à conclusão que se trata de um ritmo que é influenciado pelos 
tambores ligados à manifestação do congado mineiro, tais como os ritmos Congo e Moçambique. O trecho de $O$ que foi feito devera (de Vera) tem a seguinte célula rítmica bastante presente:

Partitura 6- Célula rítmica principal de $\mathbf{O}$ que foi feito devera (de Vera) (entre 3:55 ao final).

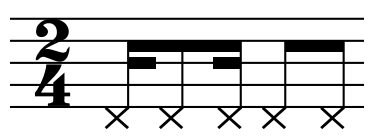

Fonte: transcrição elaborada para este trabalho.

Utilizei essa célula rítmica para fazer uma base para a música. A base foi construída a partir de um procedimento também observado em $O$ que foi feito devera (de Vera), no qual a voz cantada por Elis Regina trabalha notas repetidas e a do Milton Nascimento caminha por graus conjuntos. O texto dos vocalises escolhidos para a Festa também se aproximam do que é cantado na música $O$ que foi feito devera (de Vera).

Partitura 7 - base da música da Festa.

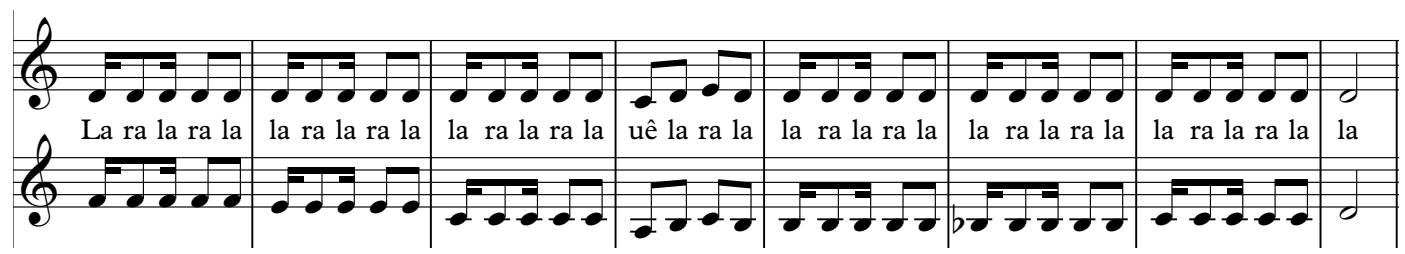

Fonte: partitura elaborada pela autora.

Ao passo que o que cantam Elis e Milton tem caráter de solo, na Festa estes vocalises se caracterizam enquanto base, uma vez que nossa instrumentação se resume a vozes e percussão. Em cima dessa base inicialmente foi construído um solo que leva a uma dualidade tonal. No trecho acima a base indica a tonalidade de Re menor (Dm). O solo composto inicialmente cadencia em Sol Maior (G), como pode ser verificado na partitura cifrada: 


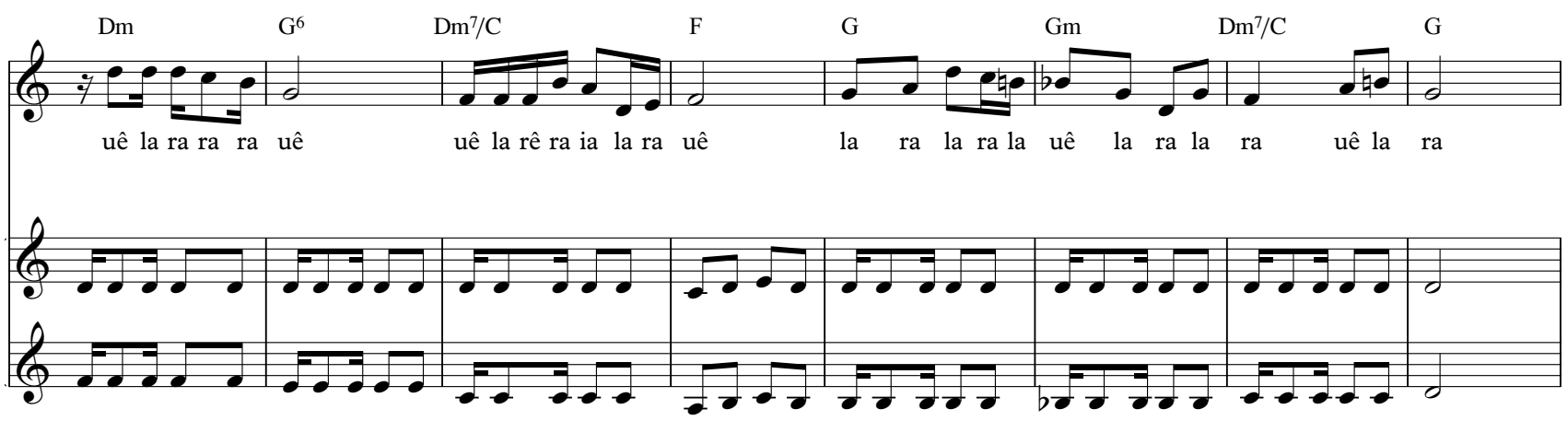

Fonte: partitura elaborada pela autora.

Desenvolvemos um arranjo coletivamente, no qual a música é iniciada com tambor e a primeira voz da base. Depois de um ciclo, entra a segunda voz da base e no ciclo seguinte, o solo. A dualidade harmônica causada pelo solo traz uma sonoridade inesperada, uma vez que surge de um modo menor para um modo maior ${ }^{51}$.

Além desse, eu e Giu de Castro desenvolvemos outros cinco solos, um para cada integrante do grupo. Giu de Castro desenvolveu três solos a partir da escuta da base, o que resultou em solos na tonalidade de Re menor e eu desenvolvi mais dois em Sol Maior. Os arranjos, no que diz respeito aos solos, foram criados da seguinte maneira: após a base ser estabelecida, a solista canta, enquanto a base também é cantada, em seguida, a percussão cessa e todas repetem o solo cantado. Então, a base com percussão retorna e, após, um ciclo inicia o solo seguinte, e assim por diante.

Uma outra perspectiva trabalhada a partir dessa música foi a questão da tessitura. Há tempos debatíamos a questão da potência da voz aguda, uma vez que, no imaginário patriarcal, a voz grave é associada à potência e ao masculino e a aguda, ao feminino e à fragilidade. Nessa perspectiva alguns dos solos - como ocorre no caso notado aqui - foram compostos pensando em explorar os agudos enquanto potência. Inclusive, quando

\footnotetext{
${ }^{51}$ Sem eu ter dito nada sobre os procedimentos utilizados para a composição, ao mostrar a gravação para um amigo ele comentou que a música parecia uma mistura de Milton Nascimento com a sonoridade do disco $O$ mistério das vozes búlgaras, do Television Female Vocal Choir. Realmente tal procedimento de ambiguidades tonais é bastante explorado nas músicas tradicionais búlgaras cantadas pelo grupo coral.
} 
apresentei a música ao grupo, isso foi imediatamente notado pela atriz/cantora Alice Máximo, que se sentiu contemplada, já que sua voz é a mais aguda do grupo.

\subsection{Considerações finais do capítulo}

Três razões do porquê nós podemos não querer definir a 'música' de forma tão estrita podem ocorrer aos leitores. Primeiro, a definição de música implicada pelas ideias aderidas à 'música por ela mesma' omite o fazer musical prático. (...) Segundo, essa é uma definição da música que exalta apenas um tipo de relação - entre a "música por ela mesma" e seu público ideal - sobre todas as relações musicais. A relação de poder entre essas entidades carrega uma semelhança desconfortável com a relação de poder característica do patriarcado, que exalta uma heterossexualidade dominada pelos homens sobre todas as outras relações humanas. Terceiro, a imagem da 'música' circunscrita pela frase 'a música por ela mesma' - à semelhança de deus, desencarnada e autônoma - carrega uma semelhança impressionante com as normas culturais da masculinidade (CUSICK, p. 492, 1999, tradução nossa ${ }^{52}$ ).

Ao discutir a ideia de "música absoluta" Suzanne Cusick apresenta três motivos para que se compreenda o porquê dessa ideia não ser o suficiente para se pensar a música. Às suas razões - que envolvem a falta de visão sobre a prática da música, a exaltação da relação entre obra e público ideal e a masculinização - acrescento a exclusão de estilos musicais e trabalho na fronteira com outras artes.

Dessa maneira, o discurso hegemônico que considera a música enquanto autônoma é pautado na noção de neutralidade, uma vez que enaltece a obra musical, autônomo de seus invólucros sociais. Nesse âmbito, as singularidades são negadas em detrimento de uma perspectiva da neutralidade e assim são desconsiderados aspectos tais quais gênero, raça, classe e, a música de tradição europeia masculinista e branca é imposta enquanto modelo ideal. O resultado de tal abordagem tradicional na música se concretiza em

\footnotetext{
52 "Three reasons why we might not want to define 'music' so narrowly may occur to readers. First, the definition of music implied by the ideas adhering to 'the music itself' omits practical music-making. (...) Second, this is a definition of music that exalts one kind of relationship - that between the 'music itself' and its ideal listener - abode all other musical relationships. The power relationship between these entities bears an uncomfortable resemblance to the characteristic power relation of patriarchy, which exalts a maledominated heterosexuality above all other human relationships. Third, the image of 'music' circumscribed by the phrase 'the music itself' - godlike, disembodied, and autonomous - bears a striking resemblance to cultural norms of masculinity" (CUSICK, p. 492, 1999).
} 
ambientes de ensino que se limitam a tratar questões da música de tradição europeia, voltados para sua escrita e na trajetória de seus compositores: homens brancos.

Realizar um trabalho com mulheres, nas fronteiras entre teatro e música, e que se propõe a investigar o canto enquanto ato criador, contraria tal discurso tradicional, uma vez que parte de práticas corpo-vocais das participantes. Nesse aspecto não negamos as palavras, mas nos apropriamos delas com a utilização do corpo. É como delineou María Xosé Queizán: “A carne é alegre e com ela escreverei muitos livros” (QUEIZÁN, p. 110, 2000, tradução nossa).

A questão estilística no Canto para o jardim de veredas surge de maneira orgânica, uma vez que o processo abarca as vontades e singularidades das participantes. Portanto, no que diz respeito aos estilos explorados, as balizas são constituídas pelos corpos em criação e não por imposição externa de um material escrito pré-concebido.

O fato de sermos mulheres e escolhermos o canto enquanto mote impulsionador causa um efeito similar ao que foi analisado no trabalho de Iara Rennó. Nos apropriamos do discurso hegemônico patriarcal que aprisiona a mulher ao canto, para assim subvertêlo e reivindicar o corpo enquanto ponto de partida para se organizar o mundo. 


\section{CONCLUSÃO}

Ao longo deste trabalho foi analisado como as artistas Jocy de Oliveira, Iara Rennó e Flora Holderbaum - ligadas a diferentes práticas - lidam com o trabalho vocal a partir de temáticas relacionadas ao corpo e gênero. Apesar de atuarem em âmbitos distintos, as três artistas têm como elo o trabalho com vocalidades que extrapolam os limites estabelecidos pelas tradições musicais. Nesse aspecto as três artistas utilizam recursos que exploram uma ampla gama sonora, envolvendo diferentes timbres, tessituras e trabalho com ruídos. Além disso, as três apresentam preocupação com aspectos performativos e tratam o corpo em primeiro plano.

No capítulo 1, foram analisadas as 5 peças para Microvocalidades de Flora Holderbaum, a partir de uma perspectiva que considera a escolha da artista em se definir enquanto performer da voz ligada à esfera da Poesia Sonora. Nesse sentido foi possível tratar da performance no âmbito dos estudos da performance propostos por Richard Schechner, assim como traçar paralelos com a teoria da performatividade de Judith Butler. Nesse aspecto há um elo entre uma visão teórica das artes e do gênero, já que ambas teorias partem da concepção do sujeito enquanto material, ligado às ações.

Ligada à esfera da Poesia Sonora - movimento artístico que traz à tona valores expressivos da vocalidade - Flora Holderbaum escolheu o trabalho com sons mínimos para explorar traços de vocalidades. Para tanto, a artista utiliza-se de recursos - desde a escrita do poema de base, à performance na gravação e utilização de processamentos eletrônicos - que evidenciam sua corporalidade.

Desse modo, foi traçado um paralelo entre os grãos sonoros abordados por Flora Holderbaum - gerados pela exploração de sons mínimos e recurso de granulação eletrônica - e o conceito de grão da voz, de Roland Barthes. Ambos trazem a ideia de uma partícula mínima de corporalidade expressada pelo uso da voz. Para Barthes, o grão da voz se dá na fricção entre a música e a língua, que se refere à materialidade do corpo que canta. Neste sentido o grão está ligado ao prazer, à corporeidade e escapa da hegemonia da semântica (BARTHES, 1986, p. 268- 270). 
Portanto, Flora Holderbaum trabalha com significados expressos pela voz que são anteriores ao campo da semântica. Ao explorar sons mínimos que envolvem recursos, como cacofonias, aliterações, trabalho com ruídos e processamentos eletrônicos, a artista parte das palavras para ressignificá-las por meio do corpo.

No capítulo 2, foi realizada a análise de Ofélia presa nas cordas do piano de Jocy de Oliveira, a partir de uma perspectiva da linguagem da ópera enquanto espaço de subversão do discurso hegemônico patriarcal. Para tanto, foi abordado o texto A ópera ou a derrota das mulheres de Catherine Clément, que trata dos papeis sombrios que as mulheres cumpriram na história da ópera, tanto no que diz respeito às histórias de vida das cantoras divas, quanto aos finais trágicos das personagens dos libretos e à função de "adorno" delegada às mulheres nas plateias das óperas.

Para falar do assunto das mulheres na ópera Jocy de Oliveira chega a citar o texto de Catherine Clémente em algumas entrevistas sobre As Malibrans, já que a artista teve a preocupação de trazer à tona tais funções relegadas às mulheres neste universo, utilizandose da linguagem da ópera para tal. Nesse sentido Jocy de Oliveira se utiliza da metalinguagem, de recursos multimídia e recursos vocais e performativos que operam em uma subversão da própria linguagem da ópera, palco que tradicionalmente carrega a tragicidade na história de vida de tantas mulheres.

Ao ser aprofundada a questão da figura da mulher associada ao canto e à morte enraizada em diversos mitos e arquétipos na cultura ocidental - foi discutida a perspectiva das vozes das Sereias, trabalhada por Adriana Cavarero. A autora trata de como o discurso hegemônico patriarcal - fundado na base da filosofia ocidental - associa valores, do que considera masculino, à esfera da razão e o que considera feminino, à esfera do corpóreo, portanto ao canto. Dessa maneira as Sereias perdem capacidade semântica no imaginário ocidental e a associação da morte ao seu canto no discurso hegemônico está ligada à potencialidade de seu corpo expressa pela voz.

Foi trabalhada nesse contexto a concepção de corpomídia proposta por Christine Greiner e Helena Katz, na qual o corpo não é apenas um meio passivo pelo qual as informações passam, mas está em fluxo constante com o ambiente. Dessa maneira corpo 
e ambiente não são passivos nem estáticos, mas se modificam constantemente. Ao tratar o corpo enquanto ativo e em primeiro plano, é possível retornar às Sereias com outro olhar, em que se liberta do corpo passivo ao qual o discurso hegemônico tenta aprisionálas e onde o canto é ressignificado.

Nesse aspecto, Paul Zumthor propõe que o termo vocalidade se reporte ao que é característico da voz e anterior à linguagem, e Adriana Cavarero acrescenta a esta ideia a fenomenologia vocálica da unicidade, que se reporta à singularidade do ser expressa pela voz, essencial para pensar um caminho que refute a ideia de neutralidade presente no discurso hegemônico patriarcal.

Portanto, uma vez que Jocy de Oliveira se utiliza no plano composicional de recursos vocais que trazem o corpo a um primeiro plano e refutam a estética do "belo" - que tradicionalmente seria conferido à personagem de Ofélia, ou às Sereias, ou às mulheres de maneira geral - o canto em Ofélia presa nas cordas do piano aparece como meio de libertação, um grito pelo corpo ativo e singular. Tal grito é concretizado na linguagem da ópera na performance realizada por Kátia Guedes e Gabriela Gerluda, que enquanto cantatrizes estão emolduradas pela noção de teatralidade e é nesse espaço criado com o público que inscrevem seu canto- performance.

No capítulo 3, foi analisado o disco Arco de Iara Rennó a partir da reivindicação pelo corpo que a artista realiza expressa por sua poética voltada para a sexualidade. Ilustrado pela caça às bruxas - abordada pelo texto de Silvia Federici - o controle do corpo ainda funciona como pilar de dominação pelos discursos que visam manter o sistema capitalista. Nesse sentido, é essencial a reivindicação do corpo para que as estruturas sejam subvertidas, tal qual Iara Rennó trabalha tanto de um ponto de vista artístico, quanto de gênero.

Em seu disco Arco Iara Rennó traz uma concepção de corpo voltada para a materialidade, ou seja, o caráter terreno e carnal do corpo. Tal ponto de vista conversa com concepções de corpo estudadas por Talitha Couto Moreira e Eduardo Viveiros de Castro em algumas etnias indígenas do Brasil. No estudo de Viveiros de Castro, o corpo aparece como uma "roupa", materialidade ligada a uma forma de acesso a um determinado 
ponto de vista. Talitha Couto Moreira aproveita tal ideia ao conectar a questão da materialidade à música e ao gênero nas etnias estudadas. A autora observa que a música também serve de "peça de roupa que ajuda a definir o gênero dos seres em questão" (MOREIRA, 2013, p. 77). Nesse sentido tanto música quanto gênero estão na esfera da ação e são caracterizados enquanto materiais e fluidos.

Portanto, Iara Rennó aproveita tal concepção sobre o corpo, não apenas ao utilizar trechos do texto de Viveiros de Castro na música Corpo selvagem, mas também na sua concepção de gênero fluido - ao caracterizar a dupla de discos Arco e Flecha na esfera do feminino e masculino, porém transgêneros - e na maneira com que trabalha as sonoridades e palavras no disco Arco.

Tanto no plano da escrita, quanto na performance da gravação, são explorados recursos que trazem a corporalidade em um primeiro plano. É valorizada uma escuta textural no que diz respeito à instrumentação pouco convencional e maneira melódica com que as linhas são exploradas, gerando tanto momentos de uníssonos, quanto polifônicos. No nível da escrita são explorados recursos da língua que trazem à tona valores expressivos da vocalidade, tal qual aliterações.

A voz aparece em Arco como maneira profunda de atestar a materialidade do corpo, uma vez que possui uma "qualidade de emanação do corpo e que o representa sonoramente de forma plena" (ZUMTHOR, 2007, p. 27). Desta maneira Iara Rennó utiliza diversos recursos que levam à escuta do corpo de carne, tais quais ruídos, risadas, gemidos, falas, percussão vocal, gritos etc.

Portanto, em Arco corpo e música estão conectados por meio da materialidade conferida pelas palavras e sonoridades trabalhadas. Dessa maneira Iara Rennó reivindica o corpo e o assume enquanto maneira de subversão das estruturas hegemônicas patriarcais.

No capítulo 4, foi discutida a perspectiva das funções e maneiras de veicular criações artísticas do ponto de vista da música e musicologia, bem como as hierarquias estabelecidas nesse âmbito. Para tanto, foram abordados tanto as artistas analisadas neste trabalho, quanto o laboratório de criação e performance realizado a partir do processo Canto para o jardim de veredas, do grupo Teatro Labirinto. 
Nesse aspecto foi abordado o texto Gênero, musicologia e feminismo, no qual a musicóloga Suzanne Cusick discute a relação entre a ideia de música absoluta e questões de gênero na musicologia. Para a autora, a persistência - pelo discurso musicológico tradicional - na ideia de uma música autônoma de seu contexto social está ligada a uma vontade de manutenção do discurso hegemônico do neutro, no qual a ideia da "obra" é elevada em relação a questões sociais que envolvem a música, inclusive o gênero. Dessa maneira a música escrita, europeia e masculinista, é considerada um modelo ideal.

Nesse sentido, Nicholas Cook discute como a perspectiva da performance na musicologia é importante para que a ideia da música absoluta seja refutada e assim as hierarquias entre música escrita e não escrita, assim como de estilos musicais, sejam subvertidas. Nessa perspectiva - ao partir do âmbito da performance - a nova musicologia considera a música enquanto fazer prático e processo de significado social e dessa maneira as hierarquias - no que diz respeito a gênero, raça, classe e estilos musicais, por exemplo - tendem a ser diluídas.

No caso do Canto para o jardim de veredas, do grupo Teatro Labirinto, a linguagem trabalhada encontra-se na fronteira entre música e teatro. Tal linguagem já descaracterizaria a ideia de uma música absoluta, não se submetendo às normas hierárquicas estabelecidas pela musicologia tradicional.

Uma vez que trabalhamos de forma colaborativa, as criações emergem das vontades e singularidades de cada integrante do grupo e, assim, arte e pesquisa são entrelaçadas e participam em um fluxo de autorreflexão e coletivização, como expresso por Camilla Veles em post de Instagram.

Figura 12- post da integrante Camilla Veles sobre o processo em Canto para o jardim de veredas, 26/04/2019. 

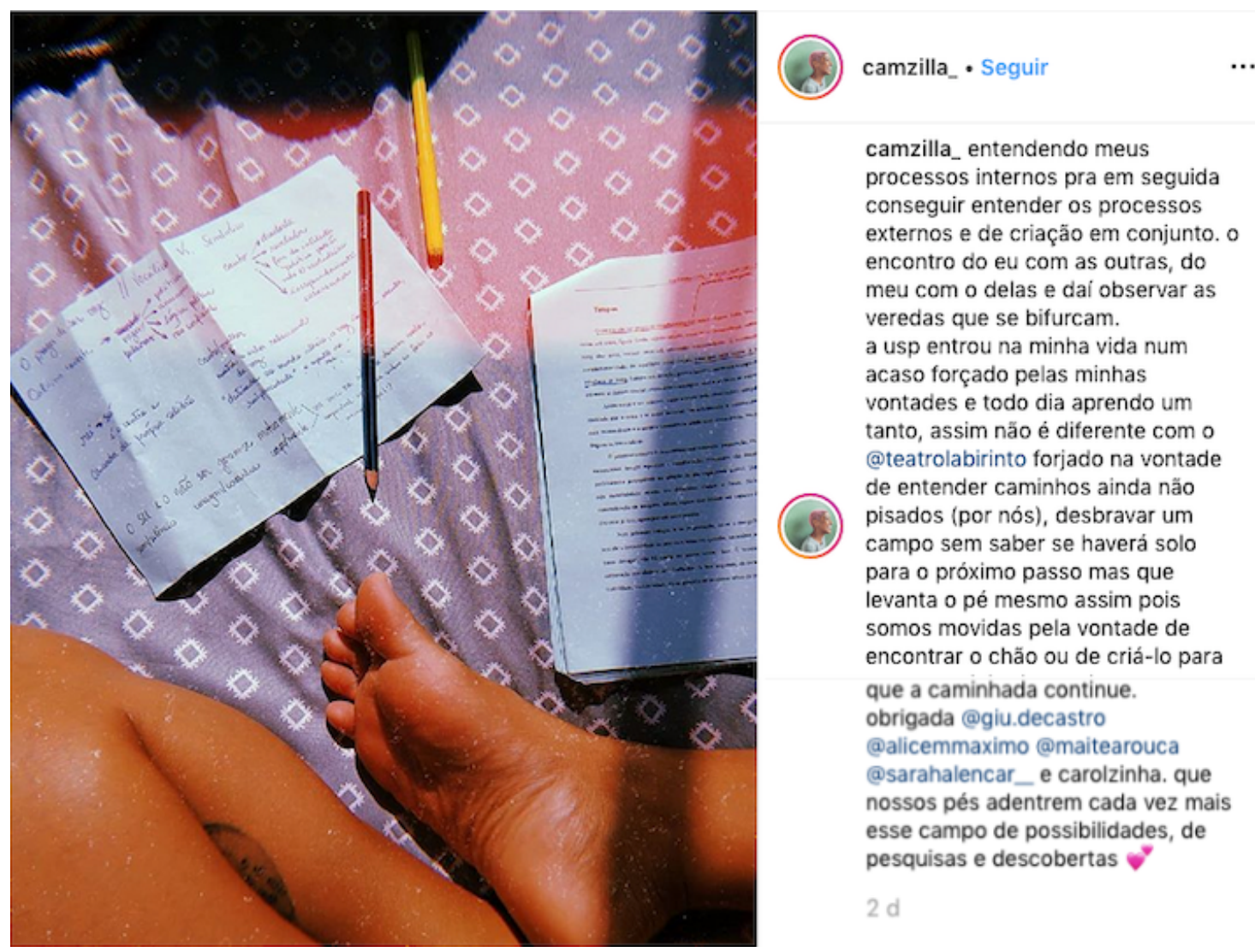

Fonte: $\underline{w w w . i n s t a g r a m . c o m}$

O fato de trabalharmos as possibilidades que emergem das singularidades provoca uma pluralidade no que diz respeito aos estilos abordados, que podem ser enquadradas tanto na esfera da música de concerto, quanto popular. Também as criações são veiculadas tanto por partituras e roteiros, quanto por gravações e ensaios.

Nesse sentido, ao pesquisarmos o canto enquanto ato criador e trabalharmos a partir de nossas singularidades, é possível conciliar a perspectiva do novo com as tradições, uma vez que estas também fazem parte de nossas singularidades. Dessa maneira, tais tradições - ao passo que reaproveitadas - são subvertidas, já que emergem associadas às singularidades e recusam o paradigma hegemônico do neutro. Dessa forma, é possível trabalhar uma linguagem que aproxime a música escrita da não escrita, a música do teatro, a música popular à música de concerto. 
Assim, a música emerge enquanto materialidade, terrena, expressa por corpos em atividade e, dessa maneira, se configura enquanto ação que caminha na direção de superar o paradigma cartesiano do discurso hegemônico patriarcal. 


\section{REFERÊNCIAS BIBLIOGRÁFICAS ${ }^{53}$}

ALVES, Sarah Alencar. A fala goiana: aspectos da música popular e erudita. Trabalho de conclusão de curso - Programa de Graduação em Música, Escola de Comunicações e Artes, Universidade de São Paulo, 2015.

BARTHES, Roland. Lo obvio y lo obtuso: Imágenes, gestos, voces. Barcelona: Ediciones Paidós Ibérica, 1986.

BORGES, Jorge Luis. O jardim de veredas que se bifurcam. Ficções. Trad: Davi Arrigucci Jr. São Paulo: Companhia das letras, 2007.

BRANDÃO, Rita Maria. Voz e processos criativos em ambientes de ensinoaprendizagem. Trabalho de conclusão de curso - Programa de Graduação em Música, Escola de Comunicações e Artes, Universidade de São Paulo, 2015.

BONAFÉ, Valéria Muelas. A casa e a represa, a sorte e o corte, ou: A composição musical enquanto imaginação de formas, sonoridades, tempos [e espaços]. Tese de doutorado - Programa de Pós-Graduação em Música, Escola de Comunicações e Artes, Universidade de São Paulo, 2016.

BUTLER, Judith. Problemas de gênero: Feminismo e subversão da identidade. Trad. Renato Aguiar. Rio de Janeiro: Civilização brasileira, 2003.

- Os atos performativos e a constituição do gênero: um ensaio sobre fenomenologia e teoria feminista. Caderno de leituras n. 78. Trad.: Jamille Pinheiro Dias. Edições Chão da feira: 2018.

CASTRO, Eduardo Viveiros de. Os pronomes cosmológicos e o perspectivismo ameríndio. Mana, v. 2, n. 2, pp. 115-144. Rio de Janeiro, 1996.

CAVARERO, Adriana. Vozes Plurais: Filosofia da expressão vocal. Trad. Flavio Terrigno Barbeitas. Belo Horizonte: Editora UFMG, 2011.

CLARKE, Eric \& COOK, Nicholas. Empirical Musicology: Aims, Methody, Prospects. New York: Oxford University Press, 2004.

\footnotetext{
${ }^{53}$ De acordo com a Associação Brasileira de Normas Técnicas (ABNT NBR 6023).
} 
CLÉMENT, Catherine. A ópera ou a derrota das mulheres. Rio de Janeiro: Rocco, 1993.

COESSENS, Kathleen. On the art of research in the arts: Tracing praxis and reflection. Art Research Journal. Brasil, Vol. 1/2, pp. 1-19, 2014.

COOK, Nicholas. Words about music, or Analysis versus performance. In: COOK, Nicholas; JOHNSON, Peter; ZENDER, Hans. Theory into practice: Composition, Performance and the Listening Experience. Leuven: Leuven University Press, 1999.

CUSICK, Suzanne. Gender, Musicology and Feminism. In: COOK, Nick; EVERIST, Mark (Ed.). Rethinking Music. New York: Oxford University Press, 1999.

DAVIS, Angela. Mulheres, raça e classe. Trad. Candiani, Heci Regina. São Paulo: Boitempo, 2016.

DIJKSTRA, Bram. Idols of Perversity: Fantasies of feminine evil in fin-de-siecle culture. Nova Iorque: Oxford University Press, 1986.

ESTES, Clarissa Pinkola. Mulheres que correm com os lobos: mitos e histórias do arquétipo da mulher selvagem. Trad. Waldéia Barcellos. Rio de Janeiro: Rocco, 1999.

DORDETE, Daiane. Possível Cartografia para um Corpo Vocal Queer em Performance. Tese de Doutorado - Programa de Pós-Graduação em Teatro, Centro de Artes, Universidade do Estado de Santa Catarina, Florianópolis, 2015.

FEDERICI, Silvia. Calibã e a bruxa: mulheres, corpo e acumulação primitiva. Trad. Coletivo Sycorax. Brasil: Editora Elefante, 2017.

FÉRAL, Josette. Performance e performatividade: o que são os Performance Studies? Sobre performatividade. Florianópolis: Letras Contemporâneas, 2009.

FONTANA, Giovanni. Oralidade, escritura, intermedialidade: enredo intermedial e trama sinestésica para os novos tecidos poéticos. In: MENEZES, Philadelpho (org.). Poesia Sonora: poéticas experimentais da voz no século XX. São Paulo: Ed. EDUC, 1992.

A poesia pré-textual. In: MENEZES, Philadelpho (org.). Poesia Sonora: poéticas experimentais da voz no século XX. São Paulo: Ed. EDUC, 1992.

GOEHR, Lydia. The Quest for Voice: on Music, Politics, and the Limits of Philosophy. London: University of California Press, 1998. 
GREINER, Christine \& KATZ, Helena. Por uma teoria do corpomídia. In: GREINER, Christine (org.). O corpo: pistas para estudos indisciplinares. São Paulo: Annablume, 2005.

HAOULI, Janete El. Demetrio Stratos - Em busca da voz-música. Londrina: edição independente, 2005.

HOLDERBAUM, Flora. 5 Peças para Microvocalidades. Revista Vórtex (Dossiê Músicas feitas por mulheres para ressoar em todos os corpos - Org: BONAFÉ, Valéria), Curitiba, v.3, n.2, pp. 241-245, 2015.

LICHOTE, Leonardo. 'Arco'e 'Flecha': dois lados de Iara Rennó, uma só arma. O Globo, p. 12, segundo caderno, junho/2016.

MENEZES, Philadelpho (org.). Poesia Sonora: poéticas experimentais da voz no século XX. São Paulo: Ed. EDUC, 1992.

MOREIRA, P. Lopes. A ciência do canto. Irmãos Vitale: Rio de Janeiro, 1940.

MOREIRA, Talitha Couto. Música, materialidade e relações de gênero: categorias transbordantes. Anppom - Estudos de gênero, corpo e música: abordagens metodológicas. Brasil: Anppom, v. 3, 2013.

NEIVA, Tania Mello. Cinco Mulheres Compositoras na Música Erudita Brasileira Contemporânea. Dissertação de Mestrado - Instituto de Artes, Universidade Estadual de Campinas, Campinas, 2006.

NOGUEIRA, Isabel Porto; PEDRO, Joana Maria \& ZERBINATTI, Camil Durões. A emergência do campo de música e gênero no Brasil: reflexões iniciais. Descentrada, vol. 2, n. 1. Universidad de La Plata, 2018.

PERNI, Remedios. Ofelia: ídolo al margen. Revista Acento. Universidad de Murcia, 2008.

PINTO, Tiago de Oliveira. Som e música: questões de uma antropologia sonora. Revista de Antropologia 44, pp. 221-286, 2001.

QUEIZÁN, María Xosé. Parir o pensamento. Escribir en femenino: Poéticas y políticas. Org. Beatriz Suárez Briones, p. 103-119. Barcelona: Icaria, 2000.

RENNÓ, IARA. língua brasa carne flor. São Paulo: Patuá Editora, 2015. 
SCAVONE, Lucila. Nosso corpo nos pertence? Discursos feministas do corpo. Gênero. Niterói, v. 10, n. 2, pp. 47-62, 2010.

SCHECHNER, Richard. Performance studies: an introduction. New York and London: Routledge, 2006.

STOROLLI, Wânia Mara Agostini. Movimento, Respiração e Canto: a performance do corpo na criação musical. Tese de Doutorado - Programa de Pós- Graduação em Música, Escola de Comunicação e Artes, Universidade de São Paulo, São Paulo, 2009.

ZUMTHOR, Paul. Escritura e Nomadismo. Trad. Jerusa Pires Ferreira e Sonia Queiroz. Cotia, SP: Ateliê Editorial, 2005.

Performance, recepção, leitura. Trad. Jerusa Pires Ferreira e Suely

Fenerich. São Paulo: Cosacnaify, 2007.

Poesia do espaço: Novos territórios para uma nova oralidade. In:

MENEZES, Philadelpho (org.). Poesia Sonora: poéticas experimentais da voz no século XX. São Paulo: Ed. EDUC, 1992.

\section{Materiais especiais}

BORGES, Marcio; BRANT, Fernando \& NASCIMENTO, Milton. O que foi feito devera (de Vera). Clube da Esquina 2. Brasil: EMI- Odeon, 1978. 1 faixa de CD.

CASTRO, Giu de. Composição dourada. São Paulo: 2019. 1 enredo-partitura.

NASCIMENTO, Milton. Clube da Esquina 2. Brasil: EMI- Odeon, 1978. 1 CD.

OLIVEIRA, Jocy de. As malibrans. Brasil, Alemanha: ABM Digital, 2000. 1 DVD (83 $\min )$.

OLIVEIRA, Jocy de. Ofélia presa nas cordas do piano. Rio de Janeiro: Musica Brasilis, 2016. 1 partitura [4 p.]. Atriz/cantora, piano/objeto.

RENNÓ, Iara. Arco e flecha. São Paulo: Circus Produções, 2016. 2 CDs. 


\section{ANEXO}

Tabela 3 - Produção artística entre 2017 e 2019

\begin{tabular}{|c|c|c|c|}
\hline PROJETO & $\begin{array}{l}\text { DESCRIÇÃO DO } \\
\text { PROJETO }\end{array}$ & $\begin{array}{c}\text { ATIVIDADES DA } \\
\text { AUTORA }\end{array}$ & PRINCIPAS EVENTOS \\
\hline A Clara do Ovo & $\begin{array}{l}\text { Espetáculo teatral } \\
\text { do grupo Arte e } \\
\text { Fatos de Goiânia. }\end{array}$ & $\begin{array}{l}\text { Composição e canto na } \\
\text { gravação da trilha } \\
\text { musical do espetáculo. }\end{array}$ & $\begin{array}{l}2017 \text { (05/Maio)- Estreia do } \\
\text { espetáculo no Teatro SESC } \\
\text { Centro, Goiânia. } \\
\end{array}$ \\
\hline Coro Profana & $\begin{array}{l}\text { Grupo de } \\
\text { experimentação } \\
\text { vocal e corporal que } \\
\text { desenvolveu } \\
\text { concerto-jogos a } \\
\text { partir de estudos de } \\
\text { gênero e voz, com } \\
\text { base bibliográfica } \\
\text { no livro Vozes } \\
\text { Plurais, de Adriana } \\
\text { Cavarero, que é } \\
\text { também utilizado } \\
\text { neste mestrado. }\end{array}$ & $\begin{array}{l}\text { Composição, canto e } \\
\text { improvisação vocal- } \\
\text { corporal. O trabalho do } \\
\text { grupo foi realizado de } \\
\text { forma colaborativa, } \\
\text { portanto sua autoria é } \\
\text { compartilhada por } \\
\text { todas/os integrantes. }\end{array}$ & $\begin{array}{l}\text { - } 2017 \text { (24/Jun)- Apresentação } \\
\text { no Estúdio Mawaca do } \\
\text { concerto-jogo Ritual de } \\
\text { Inverno. } \\
2017 \text { (28/Jul)- Participação } \\
\text { na Mostra Musical do XXIII } \\
\text { SEMINÁRIO } \\
\text { LATINOAMERICANO DE } \\
\text { EDUCAÇÃO MUSICAL em } \\
\text { Puebla-México, com } \\
\text { apresentação do concerto- } \\
\text { jogo Vozes Profanas. }\end{array}$ \\
\hline $\begin{array}{l}\text { Trio Maria } \\
\text { Fumaça }\end{array}$ & $\begin{array}{l}\text { Trio de mulheres } \\
\text { cantoras e multi- } \\
\text { instrumentistas, } \\
\text { dedicado ao } \\
\text { repertório de } \\
\text { músicas de raiz, } \\
\text { com foco na } \\
\text { produção de } \\
\text { mulheres que atuam } \\
\text { na área. Como a } \\
\text { proposta do grupo } \\
\text { envolve diferentes } \\
\text { músicas de raiz - } \\
\text { tanto que formaram } \\
\text { a música caipira e } \\
\text { regional, como } \\
\text { outras latino- } \\
\text { americanas - } \\
\text { exploramos } \\
\text { diferentes } \\
\text { vocalidades, } \\
\text { ocasionando em } \\
\text { uma rica paleta de } \\
\text { timbres e }\end{array}$ & $\begin{array}{l}\text { Arranjo, canto, violão e } \\
\text { flauta transversal. }\end{array}$ & $\begin{array}{l}\text { - } 2017 \text { (Nov - até dias atuais)- } \\
\text { Gravação do disco No } \\
\text { Caminho dos Goyazes, } \\
\text { previsto para ser lançado em } \\
\text { Junho/2018. } \\
\text { - } 2018 \text { (11/Mar) - } \\
\text { Apresentação do show No } \\
\text { Caminho dos Goyazes no } \\
\text { evento "Música Caipira em } \\
\text { Diálogoo, na Casa das Rosas, } \\
\text { São Paulo- SP. } \\
\text { 2018 (08/Abr)- Apresentação } \\
\text { do show No Caminho dos } \\
\text { Goyazes na Casa de Dona } \\
\text { Yayá, no evento Domingo na } \\
\text { Yayá. }\end{array}$ \\
\hline
\end{tabular}




\begin{tabular}{|c|c|c|c|}
\hline & $\begin{array}{l}\text { possibilidades de } \\
\text { relações entre as } \\
\text { três vozes. }\end{array}$ & & \\
\hline $\begin{array}{l}\text { Concerto de } \\
\text { conclusão da } \\
\text { disciplina } \\
\text { Criação e } \\
\text { Performance no } \\
\text { Repertório } \\
\text { Musical } \\
\text { Contemporâneo }\end{array}$ & $\begin{array}{l}\text { Concerto final dos } \\
\text { projetos } \\
\text { desenvolvidos na } \\
\text { disciplina. }\end{array}$ & $\begin{array}{l}\text { Interpretação como } \\
\text { cantora da peça } \\
\text { O'King, de Luciano } \\
\text { Berio; e composição e } \\
\text { direção de ensaio da } \\
\text { peça Estranha (jogo de } \\
\text { cartas, entre cantora e } \\
\text { instrumentista, que } \\
\text { acionam materiais } \\
\text { musicais e ações } \\
\text { performáticas, afim de } \\
\text { explorar as } \\
\text { singularidades das } \\
\text { participantes e suas } \\
\text { relações). }\end{array}$ & $\begin{array}{l}\text { - } 2017 \text { (04/Dez) } \\
\text { Apresentação do trabalho } \\
\text { composicional Estranha, } \\
\text { performado por Valentina } \\
\text { Maitá (voz) e Lucia Esteves } \\
\text { (guitarra) no Espaço das } \\
\text { Artes - USP. } \\
2017 \text { (04/Dez) - Participação } \\
\text { como cantora na realização } \\
\text { da peça O'King, de Luciano } \\
\text { Berio, no Espaço das Artes - } \\
\text { USP. }\end{array}$ \\
\hline $\begin{array}{l}\text { Forrobodó do } \\
\text { Jabah }\end{array}$ & $\begin{array}{l}\text { Grupo de forró } \\
\text { underground que } \\
\text { desenvolve o } \\
\text { trabalho músico- } \\
\text { teatral Fatiado, no } \\
\text { qual através de uma } \\
\text { linha narrativa é } \\
\text { explorado um } \\
\text { repertório de textos } \\
\text { e músicas tanto } \\
\text { autoral quanto de } \\
\text { terceiros. No show } \\
\text { são trabalhados } \\
\text { elementos que } \\
\text { exploram diferentes } \\
\text { vocalidades. }\end{array}$ & $\begin{array}{l}\text { Composição, canto, } \\
\text { flauta transversal. }\end{array}$ & 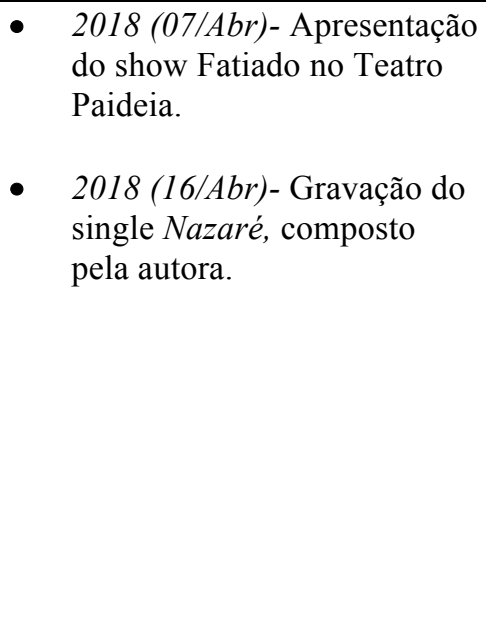 \\
\hline O Príncipe Feliz & $\begin{array}{l}\text { Espetáculo teatral } \\
\text { do grupo Teatro } \\
\text { Refinação no } \\
\text { projeto Um conto } \\
\text { dois encontros, de } \\
\text { Goiânia, } \\
\text { contemplado pela } \\
\text { Lei Goyazes de } \\
\text { Incentivo à Cultura } \\
\text { de } 2016 \text {. }\end{array}$ & $\begin{array}{l}\text { Composição, canto e } \\
\text { flauta transversal na } \\
\text { gravação da trilha } \\
\text { musical do espetáculo. }\end{array}$ & $\begin{array}{l}\text { - } 2018(25 / \mathrm{Set}) \text { - Estreia no } \\
\text { Teatro SESC Centro, } \\
\text { Goiânia. }\end{array}$ \\
\hline $\begin{array}{l}\text { Caliandra } \\
\text { Queima }\end{array}$ & $\begin{array}{l}\text { Grupo de música } \\
\text { autoral, que } \\
\text { pesquisa músicas de } \\
\text { raiz dançantes e } \\
\text { performance em } \\
\text { palco. }\end{array}$ & $\begin{array}{l}\text { Composição, arranjos, } \\
\text { produção, canto e } \\
\text { flauta transversal. }\end{array}$ & $\begin{array}{l}2018 \text { (ago) - Gravação da } \\
\text { música Primavera, parceria } \\
\text { da autora com André Larô. }\end{array}$ \\
\hline
\end{tabular}




\begin{tabular}{|c|l|l|l|}
\hline $\begin{array}{c}\text { Canto para um } \\
\text { jardim de } \\
\text { veredas }\end{array}$ & $\begin{array}{l}\text { Espetáculo teatral } \\
\text { do grupo Teatro }\end{array}$ & $\begin{array}{l}\text { Criação coletiva de } \\
\text { cenas e músicas, }\end{array}$ & $\begin{array}{l}\text { 2019 (29/Mar) - Abertura de } \\
\text { processo no V ETU } \\
\text { (Encontro de Teatro }\end{array}$ \\
& $\begin{array}{l}\text { cantemplo, SP, } \\
\text { atuaçãa, canto, }\end{array}$ & $\begin{array}{l}\text { Universitário), Campinas, } \\
\text { concepção musical. }\end{array}$ & SP. \\
\hline
\end{tabular}

